\title{
LIETUVOS KARIUOMENĖS ARTILERIJOS PABŪKLAI 1919-1940 M.
}

\author{
Vytautas Jokubauskas \\ Klaipédos universitetas \\ Egidijus Papečkys
}

XIV a. Europos mūšių laukuose atsiradusi lauko artilerija XV a. virto grèsmingu karinès galios elementu. Istorija parodè, kad mažosios valstybès, neįstengusios sukurti pakankamai efektyvių ir gausių artilerijos pajègų, nepajėgdavo atsilaikyti prieš gausesni priešą ${ }^{1}$. Baltijos regione Vokiečių ordino kariuomenès bombardos, kronikose minimos nuo 1362 m., neabejotinai pirmą kartą buvo panaudotos jau 1374 m., o prieš lietuvius - $1381 \mathrm{~m}$. Navos pilies (siejamos su Aukštadvario piliakalniu) puolimo metu. Po metų (1382 m.) puolant Jurgenburgo pilị bombardas jau naudojo ir Lietuvos Didžiosios Kunigaikštystès (LDK) kariai². Taigi 2012 m. Lietuvos kariuomenès artilerijai sukanka 630 metų.

Maždaug $1494 \mathrm{~m}$. artilerija, pabūklą užkèlus ant lafeto su ratais, tapo judri³ . Tai praplètė jos taktines galimybes. $1514 \mathrm{~m}$. LDK kariuomenè artileriją panaudojo pasaloje - puolančios Maskvos kariuomenès pajėgos pateko i stiprią jos ugni๋ ${ }^{4}$ XVII a. pradžioje Švedijos karalius Gustavas II Adolfas standartizavo savo kariuomenès artilerijos pabūklus pagal kalibrą $(24,12$ ir 3 svarų). Kiekvienas pulkas turèjo keturis 3 svarų pabūklus, iš kurių per valandą buvo galima iššauti 20 šūvių ${ }^{5}$. Po reformų patrankos tapo lengves-

\footnotetext{
1 Aleksa K. Karinio pokyčio poveikio tarptautinei sistemai interpretacijos // Lietuvos metiné strateginé apžvalga 2009-2010. Ats. red. G. Vitkus. Vilnius, 2010, p. 19-20.

2 Vaičenonis J. Lietuvos karyba nuo baltų iki XXI amžiaus. Kaunas, 2011, p. 41. Istoriografijoje abejojama dèl artilerijos Vokiečių ordino kariuomenèje $1362 \mathrm{~m}$. paminèjimo. Žr.: Rackevičius G. Arbaletas ir lankas Lietuvoje XIII-XVI a. Vilnius, 2002, p. 38.

3 Lesmaitis G. LDK samdomoji kariuomene XV a. pabaigoje-XVI a. antroje puseje. Vilnius, 2010, p. 17.

4 Vaičenonis J. Lietuvos karyba nuo baltu iki XXI amžiaus. Kaunas, 2011, p. 65.

5 Rakutis V. Karo meno istorija: nuo seniausiu laiku iki 1850 metu. Mokomoji knyga. I dalis. Vilnius, 2010, p. 166.
} 
nès, nes buvo sutrumpintas vamzdis ir suplonintos jo sienelès. Gustavo II Adolfo kariuomenès artilerija pirmoji pradejo remti pėstininkų ir kavalerijos manevrus, todèl jis laikomas „sutelktosios artilerijos ugnies tèvu“6.

Laikui bėgant, sparčiai vystantis technologijoms, artilerija nepaprastai ištobulejo ir Pirmojo pasaulinio karo metu neretai lemdavo kai kurių karo veiksmų baigti, pavyzdžiui, pagreitindavo žiedinių tvirtovių žlugimą tiek Vakarų, tiek Rytų fronte. XIX a. pradejjus gaminti graižtvinius vamzdžius, pabūkluose ịtaisius spynas, atsirado galimybė juos užtaisyti iš galo. Išsprendus atatrankos problemą ir išradus taikymosi $\mathfrak{i}$ taikinius už horizonto prietaisus, artilerija atsidūrẻ nebe priekinèse gretose, o mūšio užnugaryje. Kariuomenès masiškai pradejo gaminti judrias, greitai šaudančias 75-77 mm kalibro patrankas7 . XX a. pirmoje pusejje karo veiksmai be artilerijos praktiškai jau buvo neįsivaizduojami. Europos šalių kariuomenių ginkluoteje atsirado itin didelio kalibro artilerijos pabūklų - 280 ir $305 \mathrm{~mm}$ haubicų, $420 \mathrm{~mm}$ mortyrų. $1912 \mathrm{~m}$. bandymai Berezanès saloje (Juodojoje jūroje, prie Bugo ir Dniepro žiočių) Rusijoje parodè, kokia didelè naujųjų $280 \mathrm{~mm}$ pabūklų griaunamoji galia ${ }^{8}$. Gynybinei ginkluotei (kulkosvaidžiams) igijus persvarą, neretai puolančiųjų pajègų artilerija būdavo vienintelè veiksminga priemonè besiginančiųjų pozicijoms susilpninti, taigi pulti praktiškai buvo įmanoma tik turint artilerijos paramą. Teigiama, kad joks kitas karas nepadarè tokios didelès įtakos artilerijai kaip Pirmasis pasaulinis. Artilerija pradèti ginkluoti ịvairaus dydžio daliniai - nuo kuopos iki korpuso, ypač artilerija buvo reikšminga pagrindinio taktinio vieneto - divizijos - veiksmams igyvendinti ${ }^{9} .1940 \mathrm{~m}$. balandžio 17 d. Josifas Stalinas Raudonosios armijos vadovybès pasitarime, skirtame Žiemos karo patirčiai ịvertinti, perskaitè pranešimą, kuriame pabrèžè svarbų artilerijos vaidmenị: „Šiuolaikiniame kare artilerija yra Dievas $<\ldots>$. Kas nori persitvarkyti šiuolaikiškai, tas turi suprasti, [kad] artilerija lemia karo baigti $<\ldots . .{ }^{10}$. Anot Marko Solonino, „Antrąji pasaulinị karą

6 Vaičenonis J. Lietuvos karyba nuo baltu iki XXI amžiaus. Kaunas, 2011, p. 93.

7 Федоренко П. П. Антология научно-технической мысли в военном деле. СанктПетербург, 2007, с. 318-321.

8 Яковлев В. В. История крепостей. Москва, 2000, с. 376-386.

9 Федоренко П. П. Антология научно-технической мысли в военном деле. СанктПетербург, 2007, с. 543.

10 «Зимняя война»: работа над ошибками (апрель-май 1940 г.) Материалы комис- 
dažnai vadina „tankų karu“. Tai metafora, kuria neverta labai tikèti. Negailestingas „karo dievas“ buvo ir iki penktojo dešimtmečio pabaigos išliko artilerija. Būtent artilerijos pabūklų ugnies uraganas išvedè iš rikiuotės pusę visų karių, kurie žuvo ir buvo sužeisti"11. Tarpukario Lietuvos kariuomenès Pèstininkų statute pažymima, kad „artilerija savo ugnimi padeda praskinti kelią saviems pėstininkams arba stabdyti besiveržiantị priešą "12.

Naujausia karyba diktavo savo taisykles - kad, prieš pradedant pèstininkų puolimą, būtinas artilerinis rengimas - priešo pozicijų apšaudymas, o puolimo metu - artilerijos ugnies užtvara. Taigi natūralu, kad 1918 m. susikūrusi Lietuvos Respublika, pradejusi kurti savo kariuomenę ir 1919-1920 m. ịtraukta ị karą dèl nepriklausomybès, taip pat formavo ir artilerijos dalinius, stengèsi įsigyti artilerijos pabūklų, nes be jos palaikymo sẻkmingų karo veiksmų tikètis nevertėjo. Pirmą kartą Nepriklausomybès karo metu Lietuvos kariuomenè artileriją panaudojo $1919 \mathrm{~m}$. kovo 28 d., kai apie 15 val. Milašiūnų kaime užèmusi pozicijas baterija iš dviejų 76,2 mm patrankų apšaudè Deltuvos miestelyje ịsitvirtinusius raudonarmiečius ${ }^{13}$. Pasibaigus Nepriklausomybès karui, Lietuvos kariuomenè beveik dešimtmetị tenkinosi per karą ịsigytomis artilerijos priemonèmis. Nors jau trečiajame dešimtmetyje dèta nemažai pastangų siekiant atnaujinti artilerijos ginkluotę ir padidinti jos kiekį, reformos, susijusios su artilerijos parku, buvo igyvendintos tik XX a. ketvirtojo dešimtmečio viduryje, kai jis buvo atnaujintas ir suvienodinti ginklų kalibrai.

Šio tyrimo tikslas - išanalizuoti, kaip kito tarpukario Lietuvos kariuomenès artilerijos ginkluoté, aptariant jos techninius duomenis, kokių kontroversiškų teiginių esama istoriografijoje ir kokios tuo metu buvo Lietuvos kariuomenès artilerijos apginklavimo perspektyvos. Pažymètina, kad tekste nurodydami pabūklų ir kitos karo technikos pavadinimus, kurie ịvairiuose šaltiniuose skiriasi, stengsimès vadovautis Lietuvos kariuomenès artilerijos techninès dalies aprašymais ir statutais.

сий Главного военного совета Красной Армии по обобщению опыта финской кампании. Москва, Летний сад, 2004, с. 37.

11 Solonin M. Mozgoimenije. Suklastota Didžiojo karo istorija. Vilnius, 2011, p. 135.

12 Pestininku statutas P-51. II dalis (Kautynès). Kaunas, 1939, p. 42.

13 Sitavičius P. Pirmasis nepriklausomosios Lietuvos artilerijos šuvis // Karys, 1936, Nr. 14, p. 339. 


\section{ISTORIOGRAFIJOS KONTROVERSIJOS}

Istoriografijoje iki šiol stokojama nuoseklių ir išsamių tarpukario Lietuvos kariuomenès artilerijos ginkluotès tyrimų, kuriuos atliekant būtų išanalizuota ne tik artilerijos kiekybės problema, bet ir aptarti jos priemonių įsigijimo ir kaitos klausimai. Vis dèlto vienu ar kitu aspektu mūsų tyrimo objektas istoriografijoje aptariamas. Taip pat tenka konstatuoti, kad esama tam tikrų prieštaringų teiginių, susijusių su inž. plk. Stasio Biručio (Birutavičiaus) atsiminimais ${ }^{14}$ ir Vytenio Statkaus knyga (pastarosios autorius pažymi, jog rèmèsi tarpukario leidiniais ir išeivijos karininkų atsiminimais, kad „knygoje neišvengiamai yra informacijos spragų ir gali būti klaidų“") ${ }^{15}$.

Pirmiausia norètume aptarti keletą S. Biručio atsiminimų fragmentų, kurie istoriografijoje iki šiol eksplikuojami. Šią istoriografijos tradiciją išlaiko Vytautas Lesčius, kuris teigia, kad 1938-1940 m. Lietuva turejjo „per 120 patrankų, suskirstytų i 10 grupių. Dauguma patrankų buvo pasenusios: prancūziškos $75 \mathrm{~mm}$ Schneider Nr. 97 ir rusiškos $75 \mathrm{~mm}$ Putilov Nr. 02. Sunkiojoje artilerijoje buvo 48 pabūklai šešiose grupèse. Tai buvo $155 \mathrm{~mm}$ ir $105 \mathrm{~mm}$ vokiškos haubicos. Rezerve dar turèta angliškų $127 \mathrm{~mm}$ ir prancūziškų $155 \mathrm{~mm}$ kalibro Schneider pabūklų "16. Šie duomenys sutampa su S. Biručio atsiminimuose pateiktais ${ }^{17}$, tačiau minètų modelių pabūklus Lietuvos kariuomenè naudojo tik maždaug iki 1936 m., be to, sumažino jų skaičių. Analogiškus, kaip ir S. Birutis, skaičius pateikè Latvijos istorikas Edgaras Andersonas (Andersons) ${ }^{18}$.

Minètas išeivijos autorius rašè, kad XX a. trečiajame dešimtmetyje, siekiant suvienodinti ginkluotę, buvo keičiamasi ginklais: latviai už angliškus šautuvus Lietuvai perdavė po vieną 18 svarų angliškų ir vokišku $77 \mathrm{~mm}$ pabūklų bateriją ir vokiškų Mauser $98 \mathrm{~m}$. šautuvų ${ }^{19}$. Tačiau ty-

14 Birutis S. Lietuvos kariuomenès ginklavimasis // Karys, 1991, Nr. 5, p. 255-262.

15 Statkus V. Lietuvos ginkluotos pajegos 1918-1940 m. Chicago, 1986, p. 5.

16 Lesčius V. Lietuvos kariuomenès organizavimo, dislokavimo ir ginkluotès pokyčiai 1938-1940 m. // Karo archyvas. T. 24. Vilnius, 2009, p. 146.

17 Birutis S. Lietuvos kariuomenès ginklavimasis // Karys, 1991, Nr. 5, p. 255-262.

18 Andersons E. The Military situation in the Baltic States // Baltic defence rewiew. Nr. 6, 2001, Tartu, p. 142.

19 Birutis S. Lietuvos kariuomenès ginklavimasis // Karys, 1991, Nr. 5, p. 258. 
rimo metu mums nepavyko nustatyti, kad artilerijos ginkluotès atitinkamai padidejo, nors tarp minètų šalių pasikeitimas šautuvais ar dalies jų pardavimas vyko. S. Birutis taip pat teigia, kad kovose su bolševikais Lietuva kaip karo grobi paèmè 5 pabūklus, kovodama su bermontininkais - 7 lauko pabūklus, 1 haubicą ir 10 minosvaidžių. Anot amžininko, per Nepriklausomybės karą Lietuvos kariuomenė kaip karo grobi paėmé, gavo arba ịsigijo: 50-55 vokiškus ir rusiškus 77 ir 76,2 mm pabūklus, $12105 \mathrm{~mm}$ vokiškų haubicų, $483,8 \mathrm{~mm}$ patrankas, 8 senus angliškus $155 \mathrm{~mm}$ tvirtovių pabūklus, 16 vokiškų minosvaidžių ${ }^{20}$. Tačiau dèl angliškų $155 \mathrm{~mm}$ pabūklų tenka suabejoti, nes tokio kalibro pabūklų D. Britanijos kariuomenès ginkluotèje netgi nebuvo. Manome, autorius turèjo omenyje $127 \mathrm{~mm}$ pabūklus, kurių turèta ne 8, o 12.

V. Statkus nepagrịstai rašè, kad maždaug 1935 m. Lietuvos kariuomenès ginkluoteje atsirado švedų gamybos $81,4 \mathrm{~mm} \mathrm{Brandt} \mathrm{m} / 29$ minosvaidžių ${ }^{21}$. Šis teiginys, tikètina, pateiktas pasirèmus S. Biručio pasakojimu, kuriame paminèti švediški minosvaidžiai, tik nurodyta kita data ${ }^{22}$. Tokiu būdu, pasirèmus minètais autoriais, istoriografijoje eksplikuojama, kad „1937 m. Suomijoje nupirkta 100 švediškų $81 \mathrm{~mm}$ kalibro minosvaidžių Brandt“ ${ }^{{ }_{23}}$. Tačiau iš tikrųjų tik $1936 \mathrm{~m}$. buvo įsigyta 100 81,4 mm Brandt mod. $1934 \mathrm{~m}$. minosvaidžių ir 30000 šiems minosvaidžiams pritaikytų minų ${ }^{24}$.

Nors ir abejodamas, V. Statkus nurodo, kad $127 \mathrm{~mm}$ pabūklai, ,pasitaikius progai", buvo parduoti Etiopijai, o prasidejus Ispanijos pilietiniam karui vokiški pabūklai ir amunicija, kaip rašoma, - „vienai kariaujančių pusių “25. Tačiau dèl ginklų pardavimo Etiopijai tenka suabejoti, kadangi Italijos-Etiopijos karas prasidèjo 1935 m. spalio 3 d., o 1936 m. gegužès 7 d. Etiopija jau buvo aneksuota. Aiškejja, kad 1936 m. sausio mèn. 127 mm haubicos dar buvo Lietuvos kariuomenès ginkluotėje. Taigi $1935 \mathrm{~m}$. ginklai negalèjo būti parduoti, nes ir kariuomenès $1936 \mathrm{~m}$. ataskaitose, kur užsiminta apie vokiškų ginklų pardavimą, nèra nẻ žodžio apie angliškas

20 Ten pat, p. 256.

21 Statkus V. Lietuvos ginkluotos pajegos 1918-1940 m. Chicago, 1986, p. 531-532.

22 Birutis S. Lietuvos kariuomenès ginklavimasis // Karys, 1991, Nr. 5, p. 261.

23 Vaičenonis J. Lietuvos kariuomenès modernizacija (1926-1939) // Darbai ir dienos.

T. 21. Kaunas, 2001, p. 166.

24 Žinios apie 1936 m. ìsigytą turtą, 1937 m. sausio 9 d. LCVA, f. 1, ap. 1, b. 447, 1. 4.

25 Statkus V. Lietuvos ginkluotos pajegos 1918-1940 m. Chicago, 1986, p. 107. 
haubicas. Tad, manome, galima teigti, kad iki 1937 m. turètos angliškos $127 \mathrm{~mm}$ haubicos vis dar buvo Lietuvos kariuomenės ginkluotejje.

Tikslintinas faktas, kad angliški $83,8 \mathrm{~mm}$ pabūklai buvo parduoti Ispanijai pilietinio karo metu ${ }^{26}$. Šị teigini kartoja ir kiti autoriai ${ }^{27}$, nes turètos ginkluotès ataskaitose šie pabūklai figūravo iki pat 1940 m., o ir pasibaigus okupacijai juos naudojo 29-asis Lietuvos teritorinis šaulių korpusas ${ }^{28}$. Iš archyvinių dokumentų aiškèja, kad vis dèlto $83,8 \mathrm{~mm} \mathrm{Mk.II} \mathrm{ir} \mathrm{IV} \mathrm{pa-}$ būklus su amunicija buvo numatyta parduoti. Nors dokumentuose nenurodyta datų, galima spèti, kad tai padaryti planuota 1936-1937 m. ${ }^{29}$

Lietuvos kariuomenès turètų $20 \mathrm{~mm}$ Oerlikon pabūklų skaičius istoriografijoje ir archyviniuose dokumentuos svyruoja nuo 150 iki 182 vienetų $^{30}$. Tai, mūsų nuomone, galima paaiškinti tuo, kad jie buvo plačiai naudojami: 6 pabūklais Landsverk 181-29/34 buvo ginkluoti šarvuočiai, 2 pabūklais Oerlikon (Nr. 97 ir Nr. 98) - mokomasis karo laivas Prezidentas Smetona ${ }^{31}$, dalis pabūklų buvo skirta LTL tankams, Priešlèktuvinès apsaugos rinktinei, pèstininkų daliniams prieštankinei gynybai vykdyti, nors iš jų buvo galima apšaudyti ir oro taikinius. Todèl iš ginkluotès ataskaitu neaišku, ar ten nurodomi tik péstininkų daliniuose esantys pabūklai, ar taip pat ir šarvuočiuose bei karo laive ịrengti. Tyrimą atliekant surinkta medžiaga leidžia teigti, kad iš viso Lietuva buvo įsigijusi $18220 \mathrm{~mm}$ Oer-

26 Ten pat, p. 108.

27 Kasparavičius A., Mieliauskas T. Lietuvos-Lenkijos santykiai ir Lietuvos kariuomenès modernizavimas 1926-1939 metais // Karo archyvas. T. 15. Vilnius, 1998, p. 151.

28 Korpuso artilerijos pulkuose buvo $983,8 \mathrm{~mm}$ pabūklai. Žr.: Čapenko A. Lietuvos liaudies armijos reorganizavimo ị 29-ąj Raudonosios armijos šaulių pulką istorija 19401941 m. // Karo archyvas. T. 22. 2007, p. 359.

29 Liste du matèriel pouvant être cèdè à l'étranger, mašinraštis prancūzų kalba, nenurodytas sudarytojas ir data. LCVA, f. 3, ap. 1, b. 472, 1. 22; Sąrašas Anglu patranku Marks IV ir I ir ju kai kuriu priedu ir amunicijos. LCVA, f. 3, ap. 1, b. 472, 1. 28; Verpackungs nachwais des Materials laut Liste Nr. / u. N. 2, mašinraštis, nenurodytas sudarytojas ir data. LCVA, f. 3, ap. 1, b. 472, 1. 32-33.

30 V. Statkus nurodè, kad buvo nupirkti 156 pabūklų, iš jų 6 - šarvuočiams, o 1938 m. gruodžio mèn. gauti dar 26 pabūklai, iš jų 25 - šarvuočiams (tankams). Žr.: Statkus V. Lietuvos ginkluotos pajegos 1918-1940 m. Chicago, 1986, p. 534. Anot A. Pociūno, 1939 m. kariuomenè turèjo 151 šveicarišką 20 mm Oerlikon automatinị pabūklą ir 103636 jų šovinius. Žr.: Pociūnas A. Mūsų artilerija 1939-1940 metais // Karys, 1998, Nr. 39, p. 8.

31 Surgailis G. Lietuvos karinis laivynas 1935-1940. Vilnius, 2003, p. 88, 91. 
likon pabūklus, iš jų 6 šarvuočiams ir 25 tankams apginkluoti.

Tenka patikslinti ir vokiškų $20 \mathrm{~mm}$ automatinių pabūklų ịsigijimo duomenis, nes V. Statkus rašo, kad Lietuvos kariuomenè buvo užsisakiusi Vokietijoje $20 \mathrm{~mm}$ automatinių pabūklų Flak 28. Anot plk. ltn. Kazio Ališausko, šie ginklai buvo pirkti $B W$ firmoje, o inž. Jurgis Mikaila teigia, kad buvo ìsigyta 200 pabūklų Zemerda (Sömmerda) mieste įsikūrusioje įmonèje Gustlof-Werke ${ }^{32}$. Tačiau mums nepavyko aptikti Lietuvos kariuomenès dokumentų, kuriuose būtų paminètas pabūklas Flak 28. Yra žinoma, kad $20 \mathrm{~mm}$ pabūklų Flak 28 Vokietijos kariuomenè (Flak 29 - karinis laivynas) pirko Šveicarijoje ir kad Vokietijoje jie nebuvo gaminami ${ }^{33}$. Susipažinus su lekktuvinio automatinio pabūklo (LAP) techninès dalies aprašymu ${ }^{34}$ ir išanalizavus ikonografinę medžiagą galima teigti, kad Lietuvos kariuomenè buvo įsigijusi pabūklų, kurie Vokietijos kariuomenèje buvo žinomi kaip $2 \mathrm{~cm}$ Flak30.

Arvydas Pociūnas populiariojoje literatūroje, keliose savo publikacijose, taip pat palietė Lietuvos kariuomenès artilerijos ginkluotės problemą, tačiau per du dešimtmečius atlikti šios srities tyrimai kai kuriuos istoriko pateiktus faktus privertè iš naujo įvertinti. Autorius nurodo, kad $1940 \mathrm{~m}$. Lietuvos kariuomenè turejjo $19081 \mathrm{~mm} \mathrm{Brandt} 34 \mathrm{~m}$. minosvaidžių, 110 - $75 \mathrm{~mm}$ Schneider $1897 \mathrm{~m}$. patrankų, $2-40 \mathrm{~mm}$ w.z. 36 Bofors zenitines patrankas. Tačiau, remiantis archyviniais duomenimis, teigtina, kad minosvaidžių buvo 110, veikiančių prancūziškų patrankų - 111, 6-40 mm zenitiniai pabūklai. Abejonių kilo ir dèl paminètų 4 čekiškų 105 mm (Škoda P.z.1) pabūklų - ar šie duomenys yra tikslūs ${ }^{35}$, nes tokio modelio pabūklų nei Čekoslovakijos, nei Lietuvos kariuomenèje apskritai nebuvo. A. Pociūnas paaiškino, kad klaidingai išspausdintas sutrumpinimas $P l z n$., nusakantis gamyklos, kurioje pabūklai buvo pagaminti, vietą - Pilzno miestą.

Aptariant istoriografiją derètų pažymėti, kad $2155 \mathrm{~mm}$ haubicomis Lietuvos kariuomenès artilerijos parkas pasipildè ne XX a. ketvirtajame dešimtmetyje ${ }^{36}$, o dar Nepriklausomybès kovų laikotarpiu. Sandra Grigaravičiūtè, remdamasi istoriografija, konstatavo, kad Lietuva Švedijos

32 Statkus V. Lietuvos ginkluotos pajegos 1918-1940 m. Chicago, 1986, p. 537-538.

33 Müller W. German 20 mm Flak in WWII, 1935-1945. Atglen, 1995, P. 3.

$3420 \mathrm{~mm}$ lekktuvinis automatinis pabūklas (LAP). Technika. P-85. Kaunas, 1940.

35 Pociūnas A. Lietuvos kariuomenè 1939-1940 metais // Kardas, 1994, Nr. 7-8, p. 16-17.

36 Kasparavičius A., Mieliauskas T. Lietuvos-Lenkijos santykiai ir Lietuvos kariuomenès modernizavimas 1926-1939 metais // Karo archyvas. T. 15. Vilnius, 1998, p. 152. 
Bofors firmoje 1932 m. pirko patrankų ir haubicų už 42500 Švedijos kronų ir amunicijos už 647075 kronas, iš viso 1932-1940 m. Krašto apsaugos ministerija (KAM) šioje šalyje ịsigijo ginklų ir amunicijos už beveik 2 mln. kronų ${ }^{37}$. Tačiau mums nepavyko nustatyti, kokios patrankos ar haubicos buvo ten pirktos $1932 \mathrm{~m}$., o ir pats pirkimo faktas kelia abejonių. Nors, kita vertus, galima daryti prielaidą, kad artilerijos pabūklai buvo tik remontuojami, o perkamos jų dalys, nes $1930 \mathrm{~m}$. plk. ltn. S. Birutis vyko ị Švedijos Johansson ir Bofors firmas priimti užsakytų prekių ${ }^{38}$.

Pažymètina, kad 2007 m. išleistos Visuotinès lietuvių enciklopedijos skyriuje Krašto apsauga taip pat pateikti netikslūs Lietuvos kariuomenès artilerijos pabūklų skaičiai. Rašoma, kad $1940 \mathrm{~m}$. Lietuvos kariuomenè turëjo 350 lengvụjų $20 \mathrm{~mm}$ pabūklų ${ }^{39}, 109-105 \mathrm{~mm}$ haubicas ir tik 36 minosvaidžius ${ }^{40}$. Netikslu teigti, kad $1938 \mathrm{~m}$. Lietuva Čekoslovakijos firmoje Škoda užsakè vieną $105 \mathrm{~mm}$ patrankų grupę, t. y. 3 baterijas po 4 pabūklus ${ }^{41}$, nes buvo užsakyti (tiesa, negauti) 24 pabūklai.

Lenkijos istorikas Janas Rutkiewiczius pateike keletą ne visai tiksliu faktų apie tarpukario Lietuvos kariuomenès artilerijos ginkluotę nuro-

37 Grigaravičiūtė S. Skandinavija Lietuvos diplomatijoje 1918-1940 metais. Vilnus, 2002, p. 152-153.

38 Tiekimo valdybos 1930 m. rugpjūčio 12 d. raportas. LCVA, f. 3, ap. 1, b. 130, 1. 10.

39 Preliminariai galima būtų teigti, kad Lietuvos kariuomenè daugiausia turèjo 346 ịvairius 20 mm pabūklus: 151 Oerlikon buvo skirtas sausumos kariuomenei, 6 Oerlikon pabūklai Landsverk 181-29/34 - i̇rengti šarvuočiuose, 25 minèto tipo pabūklai - nupirkti naujiems LTL tankams apginkluoti, 150 turèjo $2 \mathrm{~cm}$ Flak 30 priešlèktuvinių pabūklų, $1420 \mathrm{~mm}$ aviacinių Hispano-Suiza pabūklų buvo sumontuoti lèktuvuose.

40 Iš dalies teisingai nurodoma turèjus $11475 \mathrm{~mm}$ patrankų, tik 3 iš jų kautynèms netiko. Teisingai rašoma, kad kariuomenè turejjo 19 76,2 $\mathrm{mm}$ patrankų, 9 - $75 \mathrm{~mm}$ zenitinius pabūklus ir 2 - $155 \mathrm{~mm}$ haubicas. Neminima buvus $83,8 \mathrm{~mm}$ ir $105 \mathrm{~mm}$ patrankų. Kitos ginkluotès skaičiaus tikslumas taip pat kelia abejonių. Žr.: Visuotine lietuvių enciklopedija. T. 12. Vyr. red. A. Račas. Vilnius, 2007, p. 209; pakartotas leidimas - Lietuva. Vyr. red. A. Račas. Vilnius, 2008, p. 335.

41 Bukelevičiūtè D. Lietuvos ir Čekoslovakijos dvišalių santykių dinamika 1918-1939 metais. Vilnius, 2010, p. 238. Analogiškus duomenis, kad 1938 m. Škoda firmoje Lietuva užsakè 3 baterijas po $4105 \mathrm{~mm}$ pabūklus ir jie buvo pagaminti - viena baterija pasiekè Eitkūnus, tačiau „rusai tuo metu okupavo Lietuvą ir vokiečiai grąžino pabūklus ị Škoda dirbtuves“, pateikia S. Birutis. Žr.: Birutis S. Lietuvos kariuomenès ginklavimasis // $\mathrm{Ka}$ rys, 1991, Nr. 5, p. 261. Pastarąji faktą (apie ị Eitkūnus patekusią bateriją) mini ir A. Pociūnas. Žr.: Pociūnas A. Lietuvos kariuomenès ginkluotè ir karinè pramonè 1939-1940 m. // Mokslas ir technika, 1993, Nr. 4, p. 30. 
dęs, kad 1939 m. sausio 1 d. kariuomenè turèjo 10675 mm prancūziškas patrankas ir $69105 \mathrm{~mm}$ haubicas ${ }^{42}$. Remdamasis lietuviškąja istoriografija tam tikrų, nors ir nežymių, netikslių statistinių duomenų mūsų tyrimo tema pateikè ir Waldemaras Rezmeris, kuris parašè, kad 1940 m. birželio 15 d. Lietuvos kariuomenè turèjo 190 minosvaidžių (daugiausiai $81 \mathrm{~mm}$ ), 69 - $105 \mathrm{~mm} 1914 \mathrm{~m}$. Schneider haubicas, o 105 mm Škoda ịvardijo kaip P.z. 1 modelio patrankas ${ }^{43}$. Faktografinių netikslumų pateko ir i Estijos autorių tyrimus. Toe Nommas nurodé, kad 1939 m. rugsejjo $1 \mathrm{~d}$. Lietuvos kariuomenè turèjo 212 lauko artilerijos pabūklų: $19-76,2 \mathrm{~mm}$, 110 - $75 \mathrm{~mm}$ ir $12-83,8 \mathrm{~mm}$ patranku, $69-105 \mathrm{~mm}, 2-155 \mathrm{~mm}$ haubicas $^{44}$, tokiu būdu padidindamas patrankų skaičių $275 \mathrm{~mm}$ patrankomis ir sumažindamas haubicų skaičių $1105 \mathrm{~mm}$ haubica.

Žinoma, kai kurie mūsų aptarti istoriografijos klausimai nèra esminiai, tačiau tam tikrais atvejais minèti netikslumai neleidžia tinkamai ịvertinti Lietuvos kariuomenès ginkluotès lygio, ypač kai kalbama apie jos įsigijimo laiką ir kiekį, o netikslumai, susiję su modeliais, kai kada suprantami - jų atsirado dèl painiavos archyviniuose dokumentuose.

\section{ARTILERIJOS PABŪKLAI}

Tarpukario Lietuvos kariuomenès artilerijos parką sudarè keleto valstybių gamybos pabūklai. Iki 1935-1936 m. vyravo vokiška, vèliau prancūziška ginkluotè. Be to, naudotos Rusijos, D. Britanijos, Šveicarijos, Suomijos ir Čekoslovakijos gamybos artilerijos priemonès, 1939 m. rugsejjị iš internuotų karių buvo paimta ir lenkiškų pabūklų.

Norètume trumpai apžvelgti kai kuriuos artilerijos pabūklus ịvardijančias sąvokas, kurios neretai painiojamos, pvz., terminas "pabūklas“ dažnai tapatinamas su „patranka“, tuo tarpu „pabūklas“ vartojamas apibendrintai daugumai artilerijos sistemų (patrankai, haubicai, mortyrai ir pan.) apibrèžti. Analogiška situacija ir kitose kalbose, pvz., „pabūklas“ anglų k. - gun, vokiečių - geschütz, rusų- opydue, lenkų - działo; patranka anglų k. - cannon, gun, vokiečių - kanone, rusų - nywкa, lenkų - arma-

42 Rutkiewicz J., Kulikow W. N. Wojsko Litewskie 1918-1940. Warszawa, 2002, s. 51-53.

43 Rezmer W. Litewskie Lotnictwo Wojskowe 1919-1940. Torun, 1999, s. 66.

44 Nõmm T. Eesti suurtükivägi 1918-1940. Relvastus ja ülesehitus // Laidoneri muuseumi aastaraamat. Nr. 4. 2005, Tallinn, 1. 189. 
ta. Terminas „haubica“ (kurị laiką po Nepriklausomybès atgavimo buvo rašoma gaubica) anglų k. - howitzer, vokiečiu - haubitze, rusų - zayбuцa, lenkų - haubica. Čia išsiskiria prancūziški terminai. Aptariamuoju laikotarpiu Prancūzijoje terminas "haubica“ (obusier) buvo vartojamas ne visada: artilerijos pabūklai vadinti cannone, patrankos - „ilgaisiais“ (L, lonque), haubicos - „trumpaisiais“ (C, court) pabūklais. Kadangi mortyrų tarpukariu Lietuvos kariuomenè neturèjo, jų čia neaptarsime.

Kuo skiriasi patranka nuo haubicos? Remiantis Artilerijos enciklopediniu žinynu ${ }^{45}$, pabūklas - šaunamasis vamzdinis ginklas (didesnio negu $20 \mathrm{~mm}$ kalibro) sviediniais (minomis) šaudyti. Pabūklų tipai: patranka, haubica, mortyra, minosvaidis ${ }^{46}$. Haubica - pabūklas trumpesniu negu patrankos vamzdžiu, šaudantis iškiliąja trajektorija (pakilimo kampas iki $\left.70^{\circ}\right)^{47}$. Patran$\mathrm{ka}$ - pabūklas, šaudantis lèkštąja trajektorija ị antžeminius, antvandeninius arba oro taikinius. Jos ilgas vamzdis ( $40-80$ kalibrų), didelis pradinis sviedinio greitis (didesnis negu $700 \mathrm{~m} / \mathrm{s}$ ), didesnis už kitus pabūklus šaudymo nuotolis ${ }^{48}$. Minosvaidis - pabūklas šaudyti minomis mortyrine trajektorija ${ }^{49}$.

Tarpukario Lietuvos kariuomenèje nebuvo patrankų, kurių vamzdžio ilgis siektų 40 kalibrų, o pradinis sviedinio lèkimo greitis būtų $700 \mathrm{~m} / \mathrm{s}$, išskyrus 1940 m. pradžioje gautas patrankas Škoda. Kad ir vadinamos patrankomis (pabüklais), $20 \mathrm{~mm}$ automatinès patrankos Oerlikon, $20 \mathrm{~mm}$ automatiniai pabūklai ( $L A P)$, kaip ir minosvaidžiai, laikyti sunkiosiomis pèstininkų priemonemis ${ }^{50}$ ir nebuvo priskiriami artilerijai, tačiau šiame tyrime šie ginklai bus aptariami.

Nagrinejjamu laikotarpiu Lietuvos kariuomenès artilerija pagal pabūklų rūšis ir jų paskirtị buvo skirstoma ị lengvą̧ą (lengvosios 75, 76 ir $84 \mathrm{~mm}$ patrankos ir 105, $127 \mathrm{~mm}$ haubicos) ir sunkiają (sunkiosios $105 \mathrm{~mm}$ patrankos ir $155 \mathrm{~mm}$ haubicos) $)^{51}$. Lietuvos kariuomeneje vyravo lengvoji artilerija - patrankos, kuriomis, kaip ir kitose Baltijos šalyse, buvo ginkluoti péstininkų divizijų, taip pat atskirieji artilerijos pulkai ir grupès. Aptaria-

${ }^{45}$ Kisinas E. Artilerijos enciklopedinis žodynas. Vilnius, 2004.

46 Ten pat, p. 131.

47 Ten pat, p. 80.

${ }^{48}$ Ten pat, p. 152.

49 Ten pat, p. 111.

50 Péstininku statutas. D. 2 (Kautynès). Kaunas, 1939, p. 31. 38.

${ }^{51}$ Artilerijos statutas. II dalis. Kautynès. A-51. Kaunas, 1937, p. 15, 16. 
muoju laikotarpiu lengvosios lauko patrankos sudare didžiąją dalị praktiškai visų šalių kariuomenių lauko artilerijos parkų ginkluotès. Pirmojo pasaulinio karo pradžioje Vokietijos kariuomeneje lauko patrankų ir haubicų santykis buvo 3:1 taikos metu ir 5:1 po mobilizacijos, o karo pabaigoje 1,5:152. Prieš Antrąji pasaulinị karą haubicos didžiųjų šalių kariuomenèse pradejo išstumti lauko patrankas, o jam prasidejus toks perginklavimas dar paspartejo. Tai lèmè pagrindiniai haubicų privalumai: didesnis kalibras, sunkesnis ir galingesnis sviedinys, didesnès galimybès sunaikinti apsaugotus taikinius. Tačiau didžiąją Lietuvos kariuomenès artilerijos dalị sudare lauko patrankos; haubicų ir patrankų skaičiaus santykis iki XX a. ketvirtojo dešimtmečio vidurio buvo 4:1 (1934 m.), bet nuo 1937-1938 m. jis pakito - sudare 2:1. Apskritai Lietuvos kariuomenè permanentiškai susidūrè su sunkiosios artilerijos priemonių trūkumu (1 lentelè). Iki 1940 m. praktiškai neturèta lauko artilerijos pabūklų, kurių šūvio nuotolis būtų daugiau kaip $12 \mathrm{~km}$, išskyrus vieną $105 \mathrm{~mm}$ vokišką patranką (2 lentelè). Dèl toliašaudès artilerijos stygiaus karo metu nebūtų ịmanoma veiksmingai kovoti su priešo artilerija, apšaudyti toliau užfrontèje esančių taikinių. Neturint sunkiosios artilerijos buvo sunku sutelkti artilerijos ugni norint pralaužti priešo pozicijas ar sunaikinti įtvirtinimus. Ne mažiau svarbi sunkiosios artilerijos ugnis buvo ir gynyboje. Lietuvos kariuomeneje buvo apskaičiuota, kad $75 \mathrm{~mm} 4$ patrankų baterijai $4 \mathrm{~km}$ atstumu esančiam 1,7 ha $(140 \times 120 \mathrm{~m})$ plotui apšaudyti (3 min. artilerijos ugnies smūgis) reikejjo 80, $105 \mathrm{~mm}$ pabūklams - 60, $155 \mathrm{~mm}$ - 30 sviedinių.

Išanalizavus Štabu žinyne pateiktus duomenis galima teigti, kad $1155 \mathrm{~mm}$ sviedinys prilygo 2 ar $3105 \mathrm{~mm}$ arba 3-4 $75 \mathrm{~mm}$ (taip pat $76,2 \mathrm{~mm}$ ar $83,8 \mathrm{~mm}$ ) sviediniams pagal poveiki ${ }^{53}$. Skirtingų kalibrų sviedinių poreikis priklausẻ nuo kovos užduočių pobūdžio ir galèjo kisti į vieną ar ị kitą pusę ${ }^{54}$. Pvz.: $100 \mathrm{~m}$ dūmų uždangai per 1 val. sudaryti reikèjo 250-600 75 mm, 120-300 105 mm, 25-30 155 mm sviedinių ${ }^{55}$, t. y. vykdant šią užduotị vienas $155 \mathrm{~mm}$ sviedinys prilygo $10-2075 \mathrm{~mm}$ arba 5-10 105 mm sviedinių.

52 Engelmann J. German Light Field Artillery 1935-1945. Atglen, 1995, p. 3.

53 Štabų žinynas. Kaunas, 1938, p. 52-53.

54 Artilerijos statutas. II dalis. Kautynès. A-51. Kaunas, 1937, p. 95-109.

55 Ten pat, p. 104. 
Tarpukariu pėstininkų lydimąą artileriją sudarè minosvaidžiai, prieštankiniai ir pėstininkų pabūklai (pastarųjų Lietuva neturejo, o kaip pavyzdị galima paminèti 24 Latvijos kariuomenei priklausiusius $70 \mathrm{~mm}$ Škoda 1928 pabūklus). Galima sakyti, kad Lietuvos kariuomenèje minosvaidžių klausimas buvo išspręstas gana anksti ir palyginti nemažai jų turèta, naudoti prieštankinei ir priešlèktuvinei gynybai skirti $20 \mathrm{~mm}$ automatiniai pabūklai. Per 1936 m. prasidejusį Ispanijoje pilietinị karą atsiskleidè puikios mažo kalibro automatinių pabūklų galimybès kovoje su šarvuotąa technika ir aviacija ${ }^{56}$. Apibendrinus šią patirtį buvo teigiama, kad: „Ispanijos pilietiniame kare, kovoje su tankais, geriausių rezultatų pasiekè $20 \mathrm{~mm}$ patranka. <...> Matyt, $20 \mathrm{~mm}$ kalibras yra geriausias sprendžiant ši klausimą. <...> Mes nesuklysime darydami išvadą, kad <...> $20 \mathrm{~mm}$ patranka Oerlikon, kaip pirmosios linijos prieštankinis pabūklas, be abejonès, yra priimtiniausia. ${ }^{\text {" } 57}$

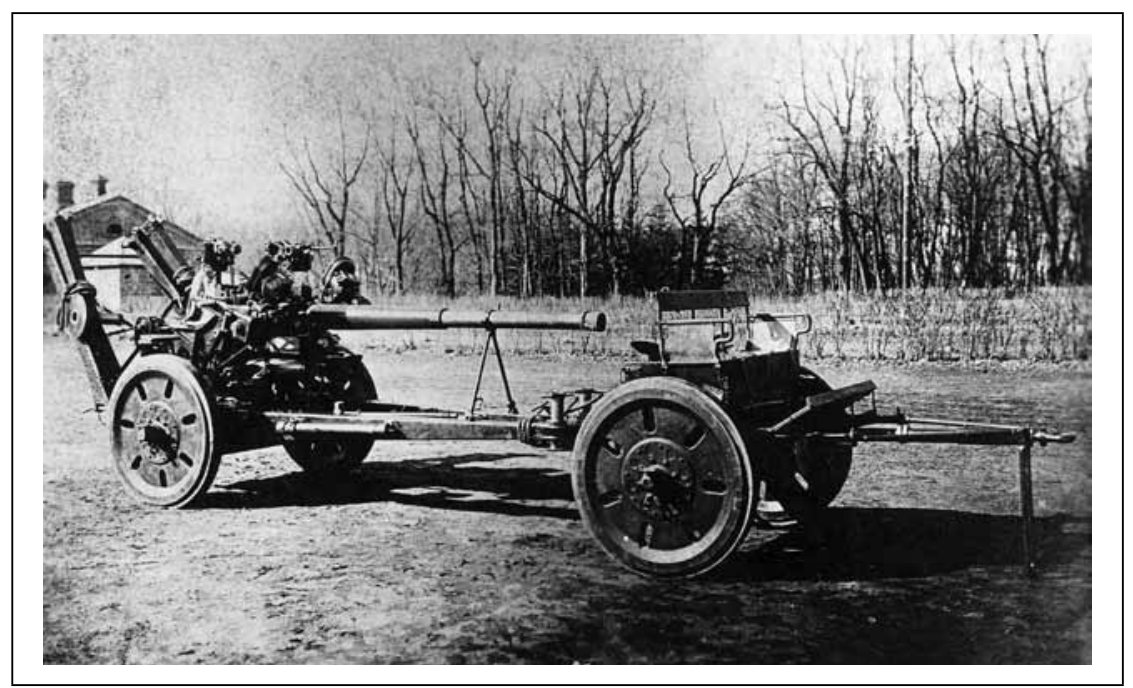

Lietuvos kariuomenės priešlèktuvinis pabūklas (75 mm Vickers modelis, Anglija), parengtas transportuoti. 1936-1940 m. (VDKM)

56 Jonaitis A. Ko pamokè Ispanijos karas // Müsuzžinynas, 1939, T. 36, Nr. 3, p. 430; Клотц Г. УрокигражданскойвойнывИспании.Москва, 1938 [žiūrèta20110429].Internetoprieiga: $<$ http://militera.lib.ru/science/klotz_h/05.html $>$.

57 Клотц Г. Уроки гражданской войны в Испании. Москва, 1938 [žiūrèta 20110429 ]. Interneto prieiga: $<$ http://militera.lib.ru/science/klotz_h/05.html $>$. 
Priešlèktuvinè artilerija mūsų tiriamuoju laikotarpiu buvo skirstoma ì lengvają, vidutinę ir sunkiąją. Lietuvos kariuomenè buvo aprūpinta lengvaisiais ir vidutiniais pabūklais, kurių šaudmenys galejo pasiekti taikinius, esančius iki 3,7 km (lengvụjų pabūklų) ir daugiau kaip 10 km aukštyje (vidutinių). Taigi bet kokị taikinị ore jie galejo kliudyti, nes tuo metu pagrindinių Lenkijos karinių oro pajègų lekktuvų didžiausias skrydžio aukštis siekė apie 10 km: naikintuvas PZL P.11 daugiausia galejo pakilti ị 10000 m (o praktiškai dažniausiai tekdavo kilti i $8000 \mathrm{~m}$ ), linijinis lèktuvas PZL.23B Karaś - i 7300 m, moderniausias bombonešis PZL.37A Łoś - į 8900 m (visiškai pakrautas - i 4 800) aukštti ${ }^{58}$. Pagrindiniai Vokietijos karinių oro pajègų lèktuvai galèjo pasiekti didžiausią aukštị: naikintuvas $B f-109$ - $10500 \mathrm{~m}$, žvalgybinis Hs 126 - $8250 \mathrm{~m}$, pikiruojamasis bombonešis $J u-87$ ir naujausias dvimotoris $J u-88-8000 \mathrm{~m}^{59}$. Tolimoji žvalgyba buvo vykdoma $2500-5000 \mathrm{~m}$, artimoji - 1500-3 000 m, kautynių metu 600-1 500 m aukštyje, naikintuvai su priešo aviacija galèjo kovoti 500-9 $000 \mathrm{~m}$, o žemès taikinius atakuoti 25-200 m aukštyje, bombarduoti žemès taikinius - iš 1 000-6000 m, nakti iš 800-1 $500 \mathrm{~m}$ aukščio ${ }^{60}$. Praktinis bombardavimo aukštis buvo kiek mažesnis. Pvz., Žiemos karo metu, bombarduojant iš $8000 \mathrm{~m}$ aukščio, bombos krisdavo per $1500 \mathrm{~m}$ nuo taikinio ${ }^{61}$. Kaip paaiškejjo dar prieš karą, dèl prasto taikiklio SSRS bombonešis $D B-3 F$ veiksmingai galèjo naikinti taikinius tik iš ne didesnio kaip $3000 \mathrm{~m}$ aukščio, praktinis bombardavimo aukštis sieke ne daugiau kaip 1 000-1 200 m, o 1941 m. vokiečių tankų ir motorizuotąsias kolonas $D B-3 F$ bombarduodavo vidutiniškai tik iš $400 \mathrm{~m}$ aukščio ${ }^{62}$. Antrojo pasaulinio karo metu Vokietijos kariuomenès pikiruojamieji bombonešiai $J u-87$ paprastai naudojo du būdus: 1) pradèdavo pikiruoti $2000-5000$ m, o bombas išmesdavo 700-1000 m aukštyje; 2) pradèdavo nuožulniai pikiruoti $1000-1500 \mathrm{~m}$, bombas išmesdavo 300-600 m aukštyje ${ }^{63}$. Be to, siekdami didesnio tikslumo, vokiečių pikiruojamụjų bombonešių pilotai išnaudoda-

58 Cynk J. B. Siły lotnicze Polski i Niemiec. Wrzesień 1939. Warszawa, 1989, s. 175, 180, 185.

59 Ten pat, s. 217, 221, 233, 239.

60 Štabų žinynas. Kaunas, 1938, p. 84.

61 Смирнов А. Боевая работа советской и немецькой авиации в Великой Отечественной войне. Москва, 2006, с. 400.

62 Ten pat, c. 376.

63 Европейская карьера Ю-87 [žiūrèta 201104 29]. Interneto prieiga: <http://www. airwar.ru/history/av2ww/axis/ju87europ/ju87europ.html>. 
vo galimybę pikiruoti nedideliame aukštyje. „Remiantis ir vokiečių, ir sovietiniais šaltiniais, $J u-87$ dažnai pikiruodavo „beveik iki pat žemès“, išeidami iš pikè skutamuoju skridimu; bet kokiu atveju jie galejo bombarduoti ir vos iš $300 \mathrm{~m}$ aukščio<...> " ${ }^{64}$ Mažo kalibro zenitinè artilerija ženkliai sumažino $J u-87$ efektyvumą: „Jeigu taikinị dengdavo mažo kalibro zenitinè artilerija, „junkerių“ ekipažai iš pradžių stengdavosi nuslopinti jų ugnị, ir tik po to būdavo suduodami smūgiai pačiam objektui. " ${ }_{65}$ Lietuvos kariuomenès turètų automatinių Oerlikon pabūklų veiksmingo šūvio ị oro taikinius aukštis siekè $2000 \mathrm{~m}^{66}$, o $2 \mathrm{~cm}$ Flak - $2200 \mathrm{~m}^{67}$, kas leido sèkmingai kovoti su priešo orlaiviais, taip pat su vèliau tapusiais legendiniais vokiečių pikiruojamaisiais bombonešiais $J u-87$.

Pakrančių apsaugos, kaip ir laivų, artilerija atsirado XV a. ${ }^{68}$ Ji buvo skirta pakrančių vandenyse veikiančioms priešo jūrų pajègoms naikinti, saviems laivams ir sausumos pajejgoms remti. XX a. pakrančių artilerija buvo skirstoma: pagal kalibrą - didelio (>130 mm), vidutinio $(100-130 \mathrm{~mm})$ ir mažo $(<100 \mathrm{~mm})$ kalibro, pagal judrumą - nejudrioji (kazematinè, bokštinè ir atviroji) ir judrioji (savaeigè ir velkamoji) ${ }^{69}$. Tarpukariu Lietuva, priešingai nei šiaurinès kaimynès ${ }^{70}$, neturèjo pakrančių apsaugos artilerijos. Manyta, kad „dèl desantų<...> mums nèra ko sielotis, nes mūsų galimiems priešams sausuma arčiau ir greičiau “"71, o kariuomenès štabe teigta, jog „Klaipèdos uostas, kaip bazè, tinka tik lenkų, rusų ir latvių atžvilgiu; gi vokiečių atžvilgiu - netinka, nes uostas karo veiksmų pradžioje gali būti užimtas iš sausumos. <...> dabartiniu metu

64 Смирнов А. Боевая работа советской и немецкой авиации в Великой Отечественной войне. Москва, 2006, с. 344.

65 Медведь А., Хазанов Д. „Юнкерс“ Ю-87. Москва, 2007, с. 57.

66 Štabų žinynas. Kaunas, 1938, p. 20.

67 Bryja M. Artyleria niemiecka 1933-1945. Warszawa, 1996, s. 122.

68 Широкорад А. Энииклопедия отечественной артиллерии. Минск, 2006 с. 81.

69 Kisinas E. Artilerijos enciklopedinis žodynas. Vilnius, 2004, p. 40.

70 Latvija, Estija ir Suomija turejo gausią pakrančių apsaugos artileriją. Lietuvos kariuomenė iki pat okupacijos neįsigijo nė vienos pakrančių apsaugos baterijos. Reikėtų pažymèti, kad minètos šalys visą savo pakrančių apsaugos artileriją paveldèjo kartu su senosiomis Rusijos imperijos pakrančių tvirtovèmis.

71 Šimkus K. Dèl straipsnio „Jūra ir jos gynimas“ // Kardas, 1938, Nr. 7, p. 169. 
[1936 m. - aut.] aktualus priešas yra vokiečiai<...>“72 Tačiau rengiant apginklavimo planą (1935-1941 m.) buvo numatyta įsigyti sunkiųjų pakrančių artilerijos pabūklų ir suformuoti judriąją (velkamąją) bateriją, tačiau iki 1939 m., kai buvo prarasta Klaipèda, šis planas nebuvo igyvendintas.

\section{LIETUVOS ARTILERIJOS PABŪKLAI NEPRIKLAUSOMYBÉS KOVŲ METU}

Pirmuosius artilerijos pabūklus Lietuvos kariuomene 1919 m. sausio $6 \mathrm{~d}$. gavo iš vokiečių. Tai buvo $276,2 \mathrm{~mm}$ rusiškos patrankos, vasario mèn. buvo perduotos dar 4 to paties kalibro patrankos. Kautynèse ties Kurkliais iš sovietinių karių buvo paimta dar $176,2 \mathrm{~mm}$ patranka ir 180 sviediniu $^{73}$. Artilerijos tiekimo skyriaus viršininko skaičiavimais, iki 1919 m. lapkričio 21 d. iš vokiečių okupacinès valdžios buvo gautos 25 ivvairios patrankos ir 33691 sviedinys $^{74} .1919$ m. kovų su bermontininkais Šiaulių ir Radviliškio rajonuose metu buvo paimtos $3150 \mathrm{~mm}$ haubicos (2 susprogdintos, 1 be spynos), 1 be spynos $100 \mathrm{~mm} 1917 \mathrm{~m}$. patranka, 2 sugadintos $105 \mathrm{~mm}$ haubicos, $877 \mathrm{~mm}$ haubicos (6 sugadintos), $376,2 \mathrm{~mm}$ patrankos (1 sugadinta), 6 sugadintos kaponieriaus $57 \mathrm{~mm}$ ir 2 sugadintos priešlektuvinès $37 \mathrm{~mm}$ patrankos, 5 sugadinti $170 \mathrm{~mm}$ ir 2 sugadinti 77 mm minosvaidžiai. Kariuomenè paèmè 66761 artilerijos sviedinị (ne vienos rūšies) ir 6104 minosvaidžio minas. $1920 \mathrm{~m}$. sausio 16 d. Lietuva iš Vokietijos gavo $2477 \mathrm{~mm}$ patrankas ir 52162 sviedinius, $12105 \mathrm{~mm}$ patrankų ir 26172 sviedinius, $15170 \mathrm{~mm}$ minosvaidžių ir 600 minų, $5250 \mathrm{~mm}$ minosvaidžius, 400 minų, $2765676,2 \mathrm{~mm}$ sviedinius ir $101677 \mathrm{~mm}$ minų ${ }^{75}$. Iš Vokietijos kaip atlyginimas už karo padarytą žalą ir kaip karo grobis iš bermontininkų Lietuvai atiteko 59 artilerijos pabūklai, 27 minosvaidžiai ir 8 bombosvaidžiai ${ }^{76} .1919$ m. gruo-

721936 m. gegužès 25 d. pasitarimo Kariuomenès štabe protokolas. LCVA, f. 929, ap. 9, b. $165,1.32-32$ ap. 1 .

73 Statkus V. Lietuvos ginkluotos pajegos 1918-1940 m. Chicago, 1986, p. 85-86.

74 Liubinas V. Mūsų ginklai 1919-1920 metais // Mūsų žinynas, 1938, T. 35, Nr. 11-12, p. 763.

75 Liubinas V. Mūsų ginklai 1919-1920 metais // Mūsų žinynas, 1938, T. 35, Nr. 11-12, p. 765. $762-37 \mathrm{~mm}$ priešlekktuvinès, $6-57 \mathrm{~mm}$ kaponierių, $1-76,2 \mathrm{~mm}, 32-77 \mathrm{~mm}, 1$ - 
džio 23 d. D. Britanija Lietuvai perdavè $483,8 \mathrm{~mm}$ II Mk patrankas ir 4000 jų sviedinių, vèliau - $12127 \mathrm{~mm}$ haubicų ir 17768 sviedinius $^{77}$. 1919 m. iš Kauno išèjus Vokietijos kariuomenei, A. Fredoje lietuviai rado $21998170 \mathrm{~mm}$ ir $11070250 \mathrm{~mm}$ minosvaidžių minų ${ }^{78}$.

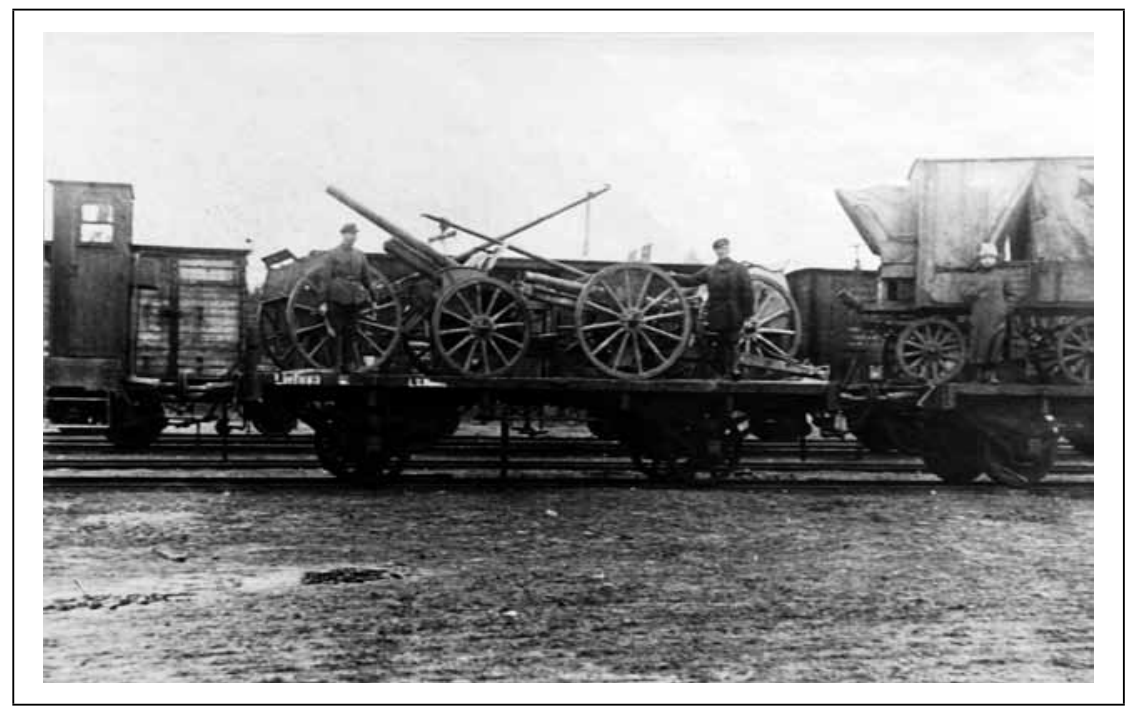

Lietuvos kariuomenès iš bermontininkų atimtos lauko patrankos (77 $\mathrm{mm}$ kalibro $1916 \mathrm{~m}$. modelio ir $77 \mathrm{~mm}$ kalibro $96 \mathrm{n}$. A. modelio) ir kitas turtas. 1919 m. (VDKM)

1920 m. liepos 18 d. Kruonio apylinkèse Lietuvos kariuomenė nuginklavo Lenkijos artilerijos brigadą ir paėmè $1675 \mathrm{~mm}$ patrankų, 2258 sviedinius, 8 bombosvaidžius ir 365 bombas. 1920 m. rugsèjo mèn., Raudonajai armijai puolant, besitraukiantys lenkai kelyje už Vilniaus paliko 2 jklimpusias $155 \mathrm{~mm}$ haubicas, ir jos atiteko Lietuvos kariuomenei. 1920 m. lapkričio 19-21 d. per kautynes prie Širvintų lietuviai iš lenkų paèmè 276,2 mm patrankas ${ }^{79}$.

$100 \mathrm{~mm}$ patrankos, $14-105 \mathrm{~mm}$ ir $3-150 \mathrm{~mm}$ haubicos, $2-77 \mathrm{~mm}, 20-170 \mathrm{~mm}$, 5 - 250 mm minosvaidžiai, 172750 - artilerijos sviedinių, 8120 - minosvaidžių minų. Žr.: Liubinas V. Mūsų ginklai 1919-1920 metais // Mūsų žinynas, 1938, T. 35, Nr. 11-12, p. 767.

77 Liubinas V. Mūsų ginklai 1919-1920 metais // Mūsų žinynas, 1938, T. 35, Nr. 11-12, p. 771.

78 Pociūnas A. Lietuvos kariuomenès minosvaidžiai 1921-1940 metais // Kardas, 2003, Nr. 2, p. 35.

79 Liubinas V. Mūsų ginklai 1919-1920 metais // Mūsų žinynas, 1938, T. 35, Nr. 11-12, 


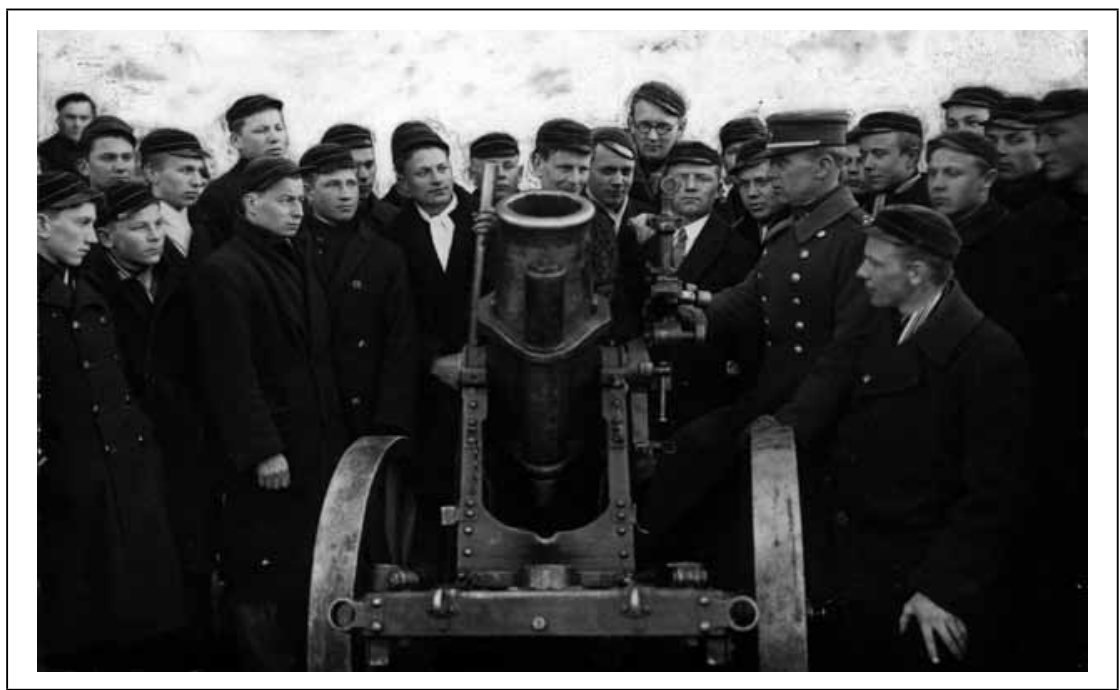

Marijampolès mokytojų seminarijos mokiniai, spejama, prie $250 \mathrm{~mm}$ sunkiojo minosvaidžio $25 \mathrm{~cm} s M W$ (Schwerer Minenwerfer) Lietuvos kariuomenès 9-ajame pėstininkų pulke. Dešinèje - kpt. Jonas Brizgys. Marijampolè Fotografas [J. ar V.] Palinauskas (LCVA)

1920 m. lapkričio 19 d. ties Širvintomis sumušus Lenkijos pajègas buvo paimti 9 minosvaidžiai. $1920 \mathrm{~m}$. gruodžio $31 \mathrm{~d}$. Lietuvos kariuomenès dalys turèjo 7 minosvaidžius, sandèliuose saugota 19 minosvaidžių, dar 8 buvo sugadinti. Sandèliuose laikytos 36084 minosvaidžių minos. Nors iš vokiečių, bermontininkų ir lenkų buvo gauta ir paimta kaip karo grobis 36 minosvaidžiai, 1920 m. pabaigoje iš jų užfiksuoti tik 34 vnt., likusių 2 likimas nežinomas ${ }^{80}$. Nuo 1919 m. sausio 27 d. iki 1920 m. pabaigos Lietuvos kariuomenè ịvairiais būdais įsigijo 118 patrankų ir haubicų, 27 minosvaidžius, 16 bombosvaidžių, 230467 artilerijos sviedinius ir 14224 minosvaidžių minas ${ }^{81}$.

p. 773-774; $1920 \mathrm{~m}$. internavus lenkų artilerijos brigadą, iš 16 paimtų patrankų 11 buvo sugadintos, kaip dauguma kitų paimtų ginklų. Žr.: Sąrašas turto, paimto iš lenkų internuotos brigados, 1920 m. LCVA, f. 3, ap. 1, b. 10, 1. 164.

80 Pociūnas A. Lietuvos kariuomenès minosvaidžiai 1921-1940 metais // Kardas, 2003, Nr. 2, p. 36.

81 Liubinas V. Mūsų ginklai 1919-1920 metais // Mūsų žinynas, 1938, T. 35, Nr. 11-12, p. 774 . 


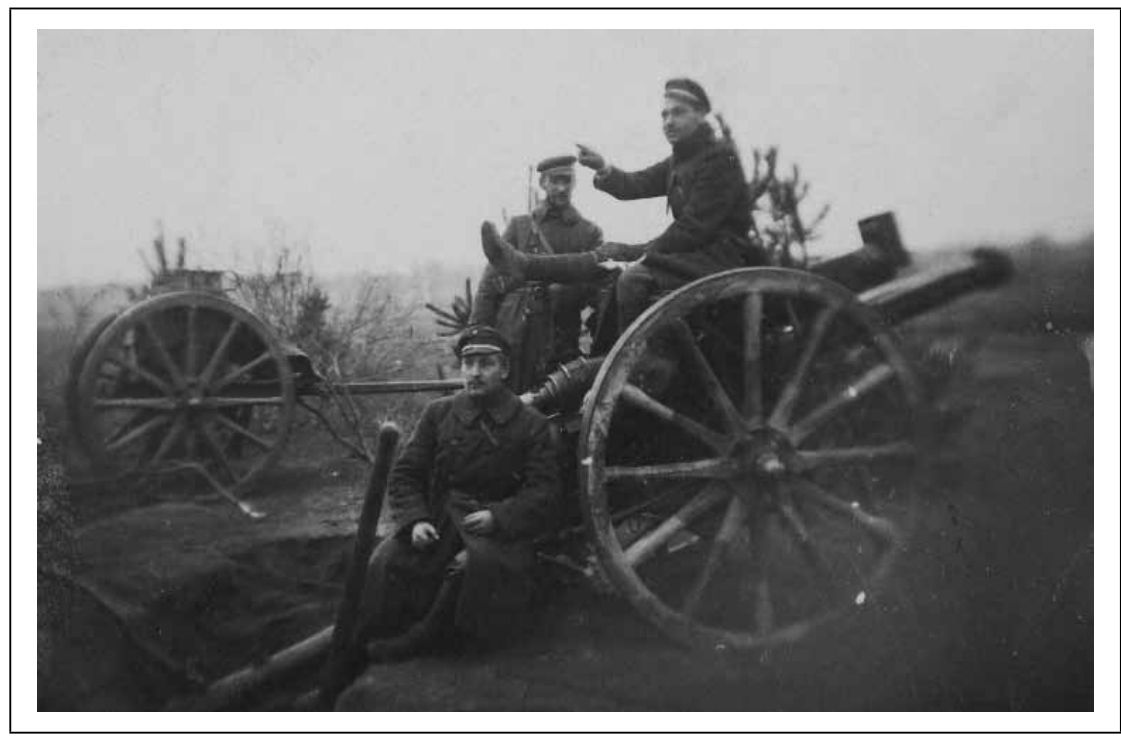

Artileristai prie $84 \mathrm{~mm}$ patrankos Vickers Mk II (D. Britanija) (privačios Algirdo Abaravičiaus kolekcijos nuotrauka)

Nepriklausomybės kovų metu ir Lietuvos artilerija patyrè nuostolių. 1920 m. rugsèjo 22-23 d. per Seinų-Druskininkų operaciją lenkai apsupo ir ì nelaisvę paèmé 2034 Lietuvos karininkus ir karius, 10 artilerijos pabūklų ${ }^{82}$.

Nepriklausomybės kovų laikotarpiu Lietuvos kariuomenė artilerijos pabūklų gavo iš Vokietijos ir D. Britanijos, nemažai jų, kaip karo grobis, buvo paimti iš lenkų, bermontininkų ir Sovietų Rusijos kariuomenių (tiesa, šie ginklai ne visada tiko kautynems). Pabūklų ir lietuviai kovų metu prarado.

\section{LIETUVOS KARIUOMENĖS ARTILERIJOS PABŪKLAI IKI $1934 \mathrm{M}$.}

Nuo 1920 iki 1926 m., per šešerius metus, Lietuvos kariuomenè negavo né vieno naujo artilerijos pabūklo, neskaitant iš lenkų paimtų $75 \mathrm{~mm}$ prancūziškų patrankų ir 155 mm sunkiųjų haubicų. Iš prancūziškų patran-

${ }^{82}$ Lesčius V. Lietuvos kariuomene nepriklausomybès kovose 1918-1920. Vilnius, 2004, p. 330 . 
kų buvo sudaryta atskira Mokomoji baterija. Pabūklų sviedinių praktiškai nebuvo pirkta, išskyrus 12500 per klaidą plk. ltn. Arvydo Jansono nupirktus. $1925 \mathrm{~m}$. buvo nupirkta 18000 rusiškų patrankų šrapnelinių sviedinių degtuvų ${ }^{83} .1923$ m. konstatuota, kad, nesant galimybių nei patiems pasigaminti, nei ịsigyti naujų ginklų, kariuomenès ginkluotẻ bus prasta. Ypač sunki buvo artilerijos padètis, nes geros būklès buvo tik $483,8 \mathrm{~mm}$ angliškos patrankos, bet joms turèta vos 1940 sviedinių. Vokiškos patrankos buvo taip susidèvejusios, kad šaudant $4 \mathrm{~km}$ nuotoliu kai kada sviedinys nuskriedavo tik $2 \mathrm{~km}$. $1923 \mathrm{~m}$. vasario $18 \mathrm{~d}$. šaudant ị lenkus ties Varèna dèl šios priežasties buvo pataikyta ị savus. Rusiškos 76,2 mm patrankos taip pat buvo labai susidèvejjusios, o ilgai laikomi sviediniai „sugedę“.

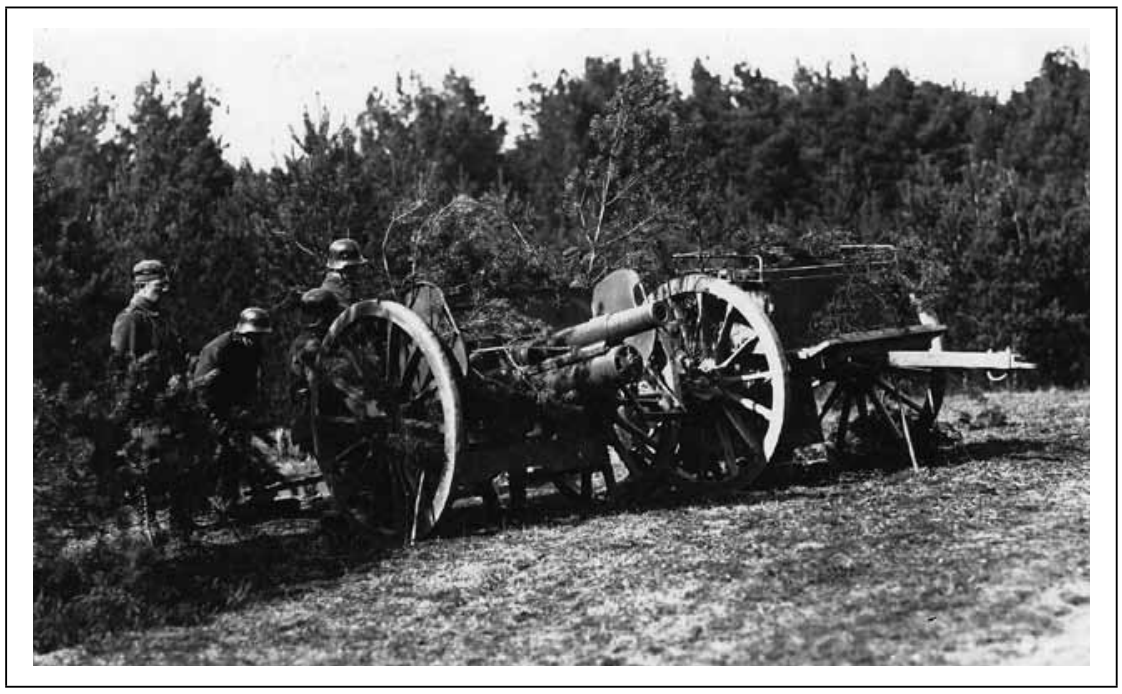

Lietuvos kariuomenès artileristai prie 76,2 mm $1902 \mathrm{~m}$. modelio rusiškos lauko patrankos. Dešinèje - sviedinių dèžè. 1927-1933 m.

A. Šulco nuotrauka, Šančiai (VDKM)

Iš archyvinių dokumentų aiškejja, kad karo atveju planuota mobilizuoti 6 PD, taigi 6 AP ir Mokomajai baterijai apginkluoti reikejo 150 pabūklų (iš jų 48 lengvųjų patrankų, 42 haubicų, 30 sunkiųjų ir 30 zenitinių pa-

83 Artilerijos organizacijos, apmokymo ir apginklavimo apyskaita laikotarpy nuo 1920 iki 1926 metų. LCVA, f. 1373, ap. 1, b. 128, 1. 71. 
būklų), o geros būklès turèta tik 30. Siūlyta suformuoti 6 minosvaidžių kuopas po 4 minosvaidžius - tam reikejo 24, o kartu su atsarginiais - 30 (kariuomenė turejo 14) minosvaidžių ${ }^{84}$. Negalint ìsigyti naujų pabūklų, turimi Kariuomenès dirbtuvèse buvo remontuojami ${ }^{85}$. Tačiau nelaimingų atsitikimų dèl prastos jų techninès būklès pasitaikè ir vèliau. $1928 \mathrm{~m}$. birželio 19 d. į Klaipèdos uostą atplaukè D. Britanijos karo laivas Canterbury. Ji pasitinkant buvo saliutuojama iš dviejų lauko artilerijos pabūklų, tačiau, šaunant 17 ar 18 kartą, sviedinys neiššovè, o pabandžius išimti, atidarius spyną, jis sprogo ir sunkiai sužeidè 2-ojo AP vyr. ltn. Nikodemą Jakučiūną ir tris kareivius, dar du kariai buvo sužeisti nesunkiai. Galiausiai vyr. ltn. N. Jakučiūnas ir eil. Šimkus nuo sužeidimų mirè $\dot{x}^{86}$.

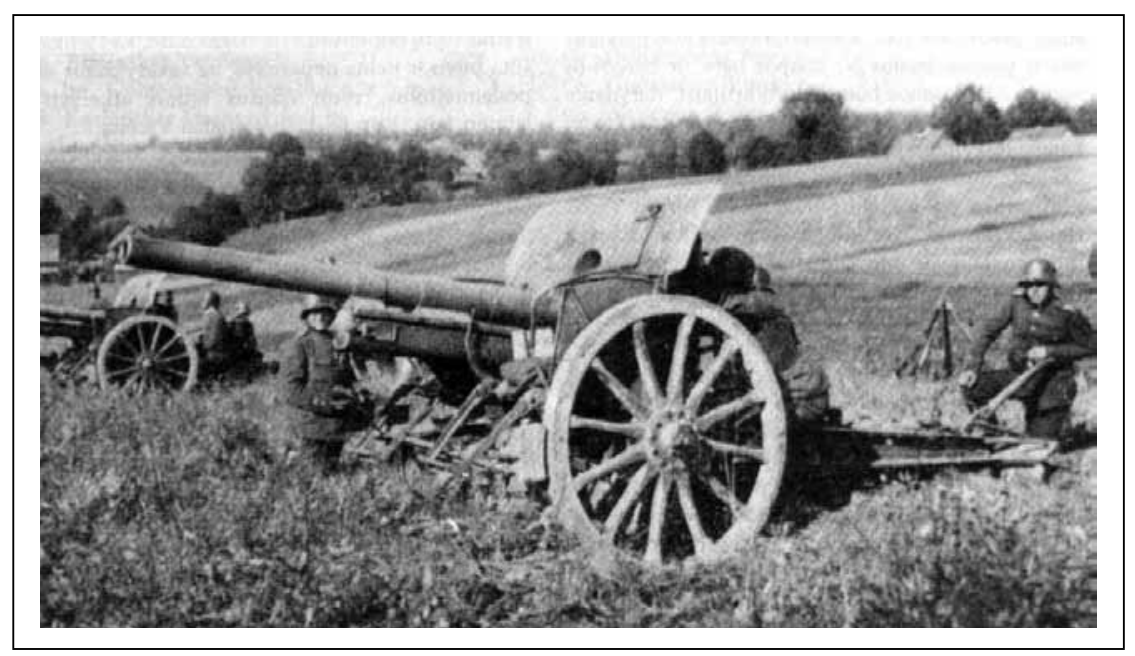

77 mm 1916 m. vokiška lauko patranka pozicijoje. $1929 \mathrm{~m}$.

Kardas, 1987, Nr. 2, p. 61

84 [dokumentas be pavadinimo] 1923 m. LCVA, f. 1373, ap. 1, b. 48, 1. 13-15 ap. 1. 1923 m. vasario 18 d. mūšio su lenkais metu 9-osios baterijos sviedinys sprogo vietovèje, kur buvo lietuvių 6-ojo PP pozicijos, ir sužeidè 4 karius, iš jų 1 mirè. Baterija turejjo apšaudyti Strzelcizki’o ir Zachary’o kaimus, kurie buvo už 7,8-8 km nuo jos pozicijų. Žr.: Artilerijos viršininko 1923 m. balandžio 6 d. ịsakymas. LCVA, f. 1373, ap. 1, b. 56, 1. 19.

851925 m. rugpjūčio 29 d. aktas Nr. 47. LCVA, f. 1373, ap. 1, b. 104, 1. 462.

86 J. G. Klaipeddos igula // Karys, 1928, Nr. 28, p. 552-553. 
1923 m. rugpjūčio 10 d. 76,2 mm patrankomis buvo ginkluotos 2-oji, 3-ioji, 4-oji, 6-oji ir 11-oji, 77 mm patrankomis - 1-oji, 5-oji, 9-oji ir 10-oji baterijos, 83,8 $\mathrm{mm}$ patrankomis - 7-oji baterija, $105 \mathrm{~mm}$ haubicomis 1-oji (3 pabūklai) ir 2-oji (4 pabūklai) haubicų baterijos, $127 \mathrm{~mm}$ haubicomis - 1-oji ir 2-oji sunkiosios artilerijos baterijos, Šarvuotųjų traukinių pulkas - 8 pabūklais: $2-75 \mathrm{~mm}, 2-76,2 \mathrm{~mm}, 2-77 \mathrm{~mm}, 2-105 \mathrm{~mm}$. Tuo metu buvo sukaupti 183953 sviediniai $(76,2 \mathrm{~mm}-31299,77 \mathrm{~mm}-$ 99 934, $105 \mathrm{~mm}$ - 33 814, 83,8 mm - 1 945, $127 \mathrm{~mm}-16961)^{87} .1924 \mathrm{~m}$. sausio $5 \mathrm{~d}$. kariuomenés daliniuose buvo 70 patrankų ir haubicų, 15 - minosvaidžių ${ }^{88}$, keturiuose artilerijos pulkuose - 55 pabūklai (1-ajame - 12, 2-ajame - 11, 3-iajame ir 4-ajame - po 16), tačiau 45 iš jų reikejo taisyti ${ }^{89}$.

Idomu, kad rusiškos 76,2 $\mathrm{mm}$ patrankos Lietuvos kariuomenejje turejjo moteriškus vardus: pvz., 2-ojoje baterijoje buvo „Danute“ (Nr. 809), „Gražina“ (Nr. 8217), „Aldona“ (Nr. 1420) ir „Birute“ (Nr. 8522) ${ }^{90}$. Tai asocijuojasi su iš lenkų paimtos patrankos pavadinimu „Zosia“ (buvo išspausdinta fotografija $)^{91}$, tačiau galima speti, kad ji savo vardą išsaugojo iki pat 1929 m., kol AG patrankų (Nr. 13101 ir Nr. 14 372) lenkiškus užrašus buvo nurodyta uždažyti ${ }^{92}$. Tyrimo metu mums pavyko nustatyti daugumos XX a. trečiajame dešimtmetyje Lietuvos kariuomenès turètų pabūklų numerius ${ }^{93}$,

87 Artilerijos viršininko valdybos 1923 m. rugpjūčio 10 d. pareiškimas. LCVA, f. 1373, ap. 1, b. 128, 1. 195-195 ap. 1.

88 Šarvuotụjų traukinių pulke buvo 8 pabūklai, Mokomojoje baterijoje - 7, 1-ajame AP 12, 2-ajame AP - 11, 3-iajame AP - 16, 4-ajame AP - 16 pabūklų. Žr.: Žinios apie turto ir ginklų sudètị 1924 m. sausio 5 d. LCVA, f. 1373, ap. 1, b. 79, 1. 11.

89 Artilerijos pabūklų stovis, 1925 m. LCVA, f. 1373, ap. 1, b. 104, 1. 871.

90 Aktas, 1924 m. rugsèjo 30 d. LCVA, f. 1373, ap. 1, b. 82, 1. 347.

91 Lietuvos kariuomenès karininkai 1918-1953. T. 5. Sud. V. Asevičius ir kt. Vilnius, 2005, p. 410 .

92 Artilerijos viršininko 1929 m. sausio 18 d. įsakymas. LCVA, f. 3, ap. 1, b. 87, 1. 10.

9337 mm zenitiniai pabūklai: Nr. 164; Nr. 167. 57 mm kaponierių pabūklai: Nr. 145; Nr. 197; Nr. 1893; Nr. 5828; Nr. 5899; Nr. 5910. 75 mm patrankos: Nr. 1408; Nr. 2009; Nr. 4237; Nr. 7212; Nr. 8613; Nr. 11121; Nr. 14480; Nr. 20449; Nr. 21614; Nr. 24177; 76, 2 mm patrankos: Nr. 566; Nr. 567; Nr. 568; Nr. 569; Nr. 809; Nr. 960; Nr. 1364; Nr. 1420; Nr. 1421; Nr. 1486; Nr. 1601; Nr. 1706; Nr. 1777; Nr. 2021; Nr. 2625; Nr. 2714; Nr. 2730; Nr. 4132; Nr. 4232; Nr. 8045; Nr. 8217; Nr. 8223; Nr. 8522; Nr. 8623. 77 mm patrankos: Nr. 4902; Nr. 7887; Nr. 11995; Nr. 14286; Nr. 17945; Nr. 19575; Nr. 26924; Nr. 33045.77 mm 1916 m. patrankos: Nr. 56; Nr. 301; Nr. 12472; Nr. 13023; Nr. 13916; Nr. 14128; Nr. 15129; Nr. 15613; 
tai ateityje galbūt gali padèti išsiaiškinti, kada ir kokiose gamyklose ginklai buvo pagaminti, kuriuose Rusijos, Prancūzijos, Vokietijos ar D. Britanijos armijų daliniuose buvo naudojami iki atiteko Lietuvos kariuomenei.

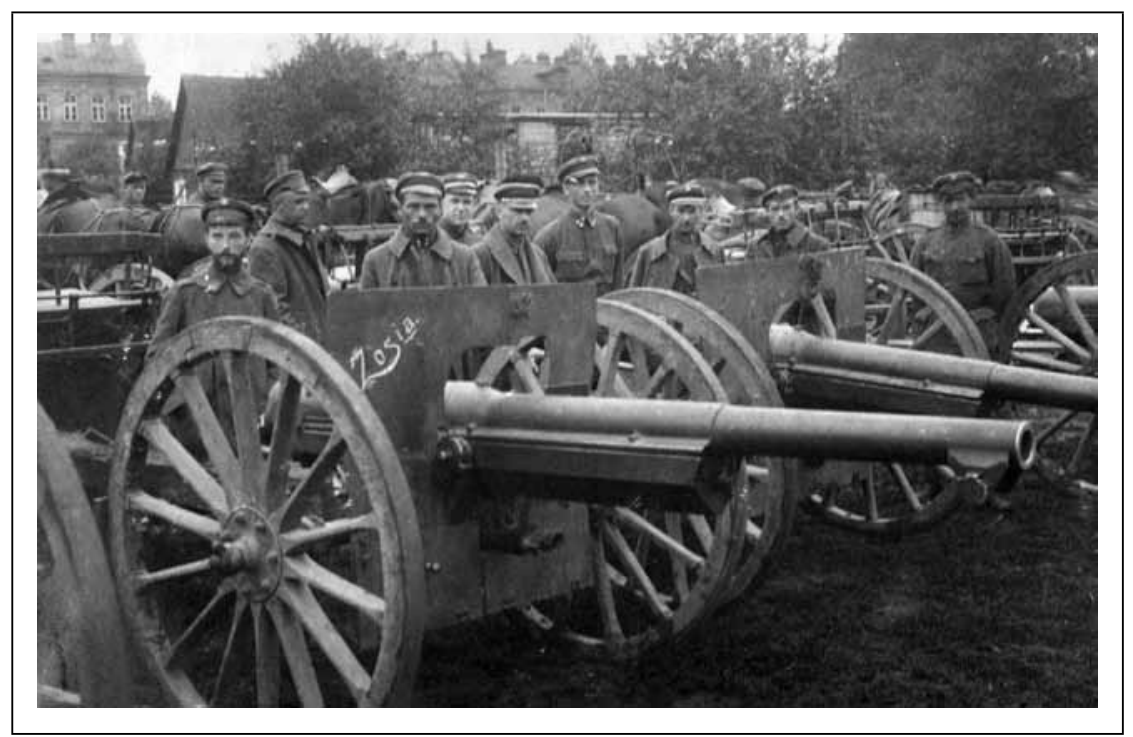

$75 \mathrm{~mm} 1897 \mathrm{~m}$. lauko patrankos (Prancūzija), atimtos iš lenkų. Kaišiadorys. 1920 m. (VDKM)

Anot istoriko Algimanto Kasparavičiaus, Lietuvos kariuomenė 1926 m. turejo apie 80 pabūklų ${ }^{94}$, tad natūralu, kad, štabui reikalaujant skirti dau-

Nr. 15618; Nr. 15808; Nr. 20056; Nr. 21700; Nr. 21719; Nr. 21937; Nr. 22014; Nr. 23045; Nr. 24795; Nr. 26924; Nr. 201769. 77 mm 1896 m. patrankos: Nr. 6139. 83,8 mm patrankos: Nr. 1947; Nr. 8639; Nr. 9826; Nr. 12558. 105 mm haubicos: Nr. 151; Nr. 237; Nr. 297; Nr. 807; Nr. 1000; Nr. 1222; Nr. 2583; Nr. 3278; Nr. 4867; Nr. 4888. 127 mm haubicos: Nr. 44; Nr. 61; Nr. 82; Nr. 123; Nr. 138; Nr. 144; Nr. 174; Nr. 180; Nr. 196; Nr. 197; Nr. 7962; Nr. 8927. Aktas, 1924 m. rugsėjo 30 d. LCVA, f. 1373, ap. 1, b. 82, 1. 347. Pabūklų pirmagalių ir šovinių dèžių stovio žinios, 1925 m. LCVA, f. 1373, ap. 1, b. 104, 1. 486-521.; 1925 m. rugpjūčio 29 d. aktas Nr. 47. LCVA, f. 1373, ap. 1, b. 104, 1. 462.; Aktas Nr. 75, 1925 m. lapkričio 13 d. LCVA, f. 1373, ap. 1, b. 104, 1. 619.; Aktas Nr. 6, 1929 m. kovo 5 d. LCVA, f. 1373, ap. 1, b. 177, 1. 77. 94 Kasparavičius A. Koalicinès liaudininkų ir socialdemokratų vyriausybès pastangos reorganizuoti kariuomenę 1926 metais // Lietuvos istorijos metraštis. 1993 metai. Vilnius, 1994, p. 62. 
giau lèšų ginkluotei įsigyti, ministras pirmininkas Mykolas Sleževičius tarèsi su SSRS atstovu, kad vietoj $1920 \mathrm{~m}$. liepos $12 \mathrm{~d}$. taikos sutartyje numatytos medienos, kurios kritusi rinkos vertė aptariamuoju laikotarpiu siekė apie $350 \mathrm{mln}$. $\mathrm{Lt}^{95}$, Sovietų Rusija Lietuvai duotų ginklų ir, anot Kazio Škirpos, buvo gavęs pažadą. K. Škirpa skubiai parenge ginklų 6 pėstininkų divizijoms ir 3 sunkiosios artilerijos pulkams sąrašą, tačiau 1926 m. gruodžio 17 d. ìvyko karinis perversmas ir, pasikeitus politinei bei karinei vadovybei, rezultatų nebuvo pasiekta - Lietuva negavo nei medienos, nei ginklų. Igyvendinusi ši projektą Lietuva būtų galèjusi apginkluoti 9-10 divizijų, o tai praktiškai buvo maksimalus skaičius dviejų su puse milijono gyventojų turinčiai šaliai ${ }^{96}$. Tačiau manome, kad perversmas nebuvo tikroji priežastis, dèl kurios Lietuva iš SSRS negavo ginklų, nes ši sovietinè didvalstybė lietuviams jų net neparduodavo, o ką jau kalbèti apie „davimą“ vietoj medienos. Tai lèmė SSRS politinis sprendimas, o ne Lietuvos vidaus politikos peripetijos.

$1926 \mathrm{~m}$. birželio $25 \mathrm{~d}$. kariuomenès daliniuose ir sandèliuose buvo: 14 75 mm prancūziškų, 18 - 76,2 mm rusiškų (iš jų 2 sudilusios - Karo mokykloje), 26 - 77 mm vokiškos patrankos, 9 - $105 \mathrm{~mm}$ vokiškos haubicos, 1 - $105 \mathrm{~mm}$ vokiška patranka be spynos, $4-83,8 \mathrm{~mm}$ ir $12-127 \mathrm{~mm}$ angliškų pabūklų, 2 - $155 \mathrm{~mm}$ prancūziški pabūklai, 2 - $37 \mathrm{~mm}$ zenitiniai ir 2 - $57 \mathrm{~mm}$ kaponieriu pabūklai97. $75 \mathrm{~mm}$ patrankos buvo tinkamos nau-

95 Pagal Lietuvos-Sovietų Rusijos 1920 m. liepos 12 d. sutartį Lietuva turèjo gauti 100000 dešimtinių (109 250 ha, nes 1 dešimtinè - 1,0925 ha) stačio miško išsikirsti, iš 1 ha miško vidutiniškai buvo galima paruošti apie $164 \mathrm{~m}^{3}$ medienos (žinoma, kiekis priklausė nuo miško brandos ir medienos tipo), iš 1 ha brandžių medynų - apie $249 \mathrm{~m}^{3}$, o plynai kertant brandų mišką - apie 200-220 m³. Žr.: Lietuvos miškų kadastras. Vilnius, 1990, p. 31, $67,86.1926 \mathrm{~m}$. Lietuva už parduotą $1 \mathrm{~m}^{3}$ gavo $15 \mathrm{Lt}$ (pardavė $1435103 \mathrm{~m}^{3}$ medienos už 21,64 mln. Lt), 1924 m. - 23 Lt/m³, 1925 m. - 14,8 Lt/m³, 1927 m. - 13,5 Lt/m³, 1928 m. $14,8 \mathrm{Lt} / \mathrm{m}^{3}$. Taigi $1924-1928 \mathrm{~m}$. Lietuvos parduotos medienos $\mathrm{m}^{3}$ kainos vidurkis buvo apie 16,22 Lt. Žr.: Lietuvių enciklopedija. T. 15. Boston, 1968, p. 201. Lietuvai pagal sutarti priklausantis miškas (apie $22 \mathrm{mln} . \mathrm{m}^{3}$ ) nupjautas galejo kainuoti apie $350 \mathrm{mln}$. Lt. Plotai pagal sutarties 12 str. 2 d. turèjo būti kuo arčiau Lietuvos sienos, plukdomųjų upių ir geležinkelių, sutartą plotą buvo numatyta iškirsti per $20 \mathrm{~m}$. Žr.: Lietuvos okupacija ir aneksija 1939-1940. Dokumentu rinkinys. Vilnius, 1993, p. 38.

96 Škirpa K. Pakeliui su Mykolu Sleževičiumi // Mykolas Sleževičius. J. Būtènas, et. al., Chicago, 1954, p. 244-246.

97 1-asis AP turèjo 12 pabūklų (1-oji baterija - $477 \mathrm{~mm}$, 4-oji baterija - 476,2 mm, 7-oji 
doti, tik joms stigo sviedinių (sandèliuose jų atsargas sudarè tik 1800 vnt.), $76,2 \mathrm{~mm}$ patrankų sviedinių sukaupta pakankamai, tik patys pabūklai buvo susidèveję. Vokiškos $77 \mathrm{~mm}$ patrankos taip pat susidèvejusios, bet naudojamos, nors beveik visi šiems pabūklams skirti užtaisai buvo sugedę. $83,8 \mathrm{~mm}$ patrankoms, kurių buvo 4, turèta tik 1800 sviedinių. Vokiškos haubicos geros, tinkamos naudoti, tačiau nebuvo joms sviedinių, o zenitiniai pabūklai - pasenę, susidèvèję, todèl nebeturèjo praktinès reikšmès ${ }^{98}$.

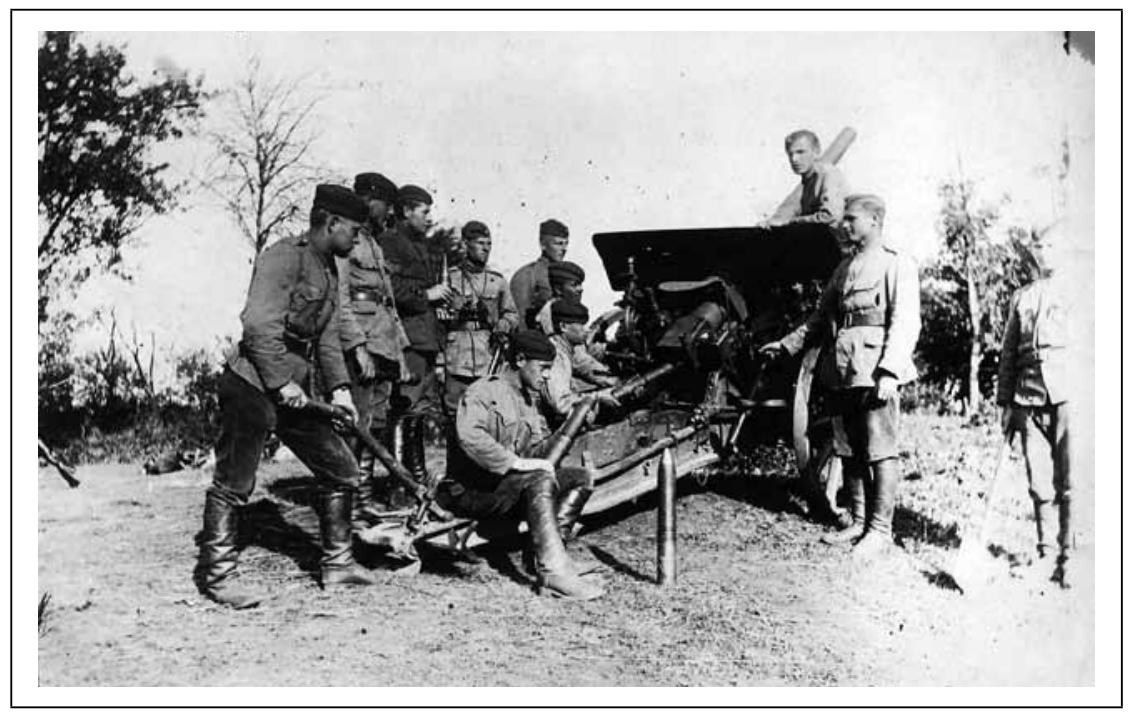

77 mm 1916 m. vokiška lauko patranka pozicijoje. XX a. trečiasis dešimtmetis (privačios Algirdo Abaravičiaus kolekcijos nuotrauka)

baterija - $483,8 \mathrm{~mm}$ ), 2-asis AP - 11 pabūklų (5-oji baterija - $477 \mathrm{~mm}$, 2-oji baterija $476,2 \mathrm{~mm}$, 1-oji haubicų baterija - $3105 \mathrm{~mm}$ ), 3-iasis AP - 16 pabūklų (9-oji baterija $477 \mathrm{~mm}, 3$-ioji ir 6-oji baterijos - 8 vokiškus 76,2 mm [kyla abejonių, ar dokumente nebuvo suklysta nurodant kalibrą - aut.], 1-oji sunkioji baterija - $4127 \mathrm{~mm}$ ), 4-asis AP - 10 pabūklų (4-75 mm, 2 - 76,2 mm (kovai netinkamus), 2 - $77 \mathrm{~mm}$ N/A, $2-37 \mathrm{~mm}$ zenitinius (menkaverčius)), Šarvuočių rinktinès traukinių batalionas -8 pabūklus $(2-75 \mathrm{~mm}$, $2-77 \mathrm{~mm}, 2-105 \mathrm{~mm}, 2-57 \mathrm{~mm}$ kaponieriu (menkaverčius), Mokomoji baterija - 2 pabūklus (76,2 mm, netinkamus kautynèms). Žr.: Vyriausiojo štabo Artilerijos inspekcijos 1926 m. birželio 25 d. raportas. LCVA, f. 1373, ap. 1, b. 128, 1. 170-173.

${ }_{98}$ Kasparavičius A. Koalicinès liaudininkų ir socialdemokratų vyriausybès pastangos reorganizuoti kariuomenę 1926 metais // Lietuvos istorijos metraštis. 1993 metai. Vilnius, 1994, p. 61-62. 
1926 m. birželio 30 d. Artilerijos inspekcija pranešè, kad Karo muziejuje yra 10 pabūklų, iš jų: 4 - 75 mm patrankos, kurių vamzdžiai geri, bet 3 - be spynų, trūksta taikiklių; 4 - $77 \mathrm{~mm} 96 \mathrm{~m}$. N/A vokiškos patrankos, kurių 1 - išdilusiu vamzdžiu, 3 - be spynų; 1 - 105 mm vokiška haubica sugadintu vamzdžiu, bet geru lafetu; 1 - 105 mm vokiška toliašaudè patranka. Siūlyta Artilerijos inspekcijai perduoti visas $75 \mathrm{~mm}$ (4 vnt.), $77 \mathrm{~mm}$ (3 vnt.) ir $105 \mathrm{~mm}$ (šio tipo patrankai sviedinių turèta, todèl konstatuota, kad, ją sutvarkius, bus bent vienas toliašaudis pabūklas) patrankas, taip pat nebetinkamas $77 \mathrm{~mm}$ patrankas ir $105 \mathrm{~mm}$ haubicos lafetus, tikintis Lietuvos kariuomenès artilerijos parką papildyti 8 pabūklais ${ }^{99}$.

1926 m. konstatuota, kad 4 PD ir šarvuočių rinktinei apginkluoti, be turimų pabūklų, dar reikètų ìsigyti 4 lengvąsias lauko ir 16 sunkiųjų patrankų, 24 haubicas, 16 zenitinių pabūklų ir $437 \mathrm{~mm}$ tankų patran$\mathrm{kas}^{100} .1926 \mathrm{~m}$. parengtame artilerijos apginklavimo projekte teigiama, kad Lietuvos kariuomenei, 3 PD ir kavalerijos brigadai (2 KP) reikètuc 178 pabūklų (68 lauko patrankų, 32 haubicų, 12 sunkiųjų toliašaudžių pabūklų, 12 zenitinių pabūklų ir 54 pèstininkų patrankų) ir 165000 sviedinių. Kariuomenè tuo metu turejjo 67 pabūklus (48 lauko patrankas, 13 haubicų ir 6 péstininkų pabūklus), 173458 sviedinius. Taigi dar reikèjo ịsigyti 111 pabūklų (20 lauko patrankų, 19 haubicų, 12 sunkiųjų toliašaudžių pabūklų, 12 zenitinių patrankų ir 48 pėstininkų pabūklus) ir 118300 sviedinių. Igyvendinti ši planą turèjo kainuoti 46,781 mln. Lt per 5 metus $^{101}$. Turimi 67 pabūklai sudarè tik 37,6 \% 1926 m. artilerijos apginklavimo plane numatyto ginkluotès (ivvairių pabūklų) kiekio, tad jų skaičiu norèta padidinti daugiau nei du su puse karto. Toki dideli artile-

\footnotetext{
99 Artilerijos inspekcijos 1926 m. birželio 30 d. raportas. LCVA, 1373, ap. 1, b. 128, 1. 179.

${ }^{100}$ Vyriausiojo štabo 1926 m. kovo 6 d. raportas. LCVA, f. 1373, ap. 1, b. 128, 1. 43.

${ }^{101}$ Kiekviena PD turejjo turèti 4 lauko artilerijos, 2 haubicų ir 1 toliašaudžių patrankų baterijas, kiekvienas batalionas - po 2 lengvąsias pėstininkų patrankas (divizija - 18 pabūklų). Iš viso $3 \mathrm{PD}$ sudarè 48 lauko patrankos, 24 haubicos, 12 sunkiųjų toliašaudžių patrankų ir 54 péstininkų patrankos. Kavalerijos brigadoje kiekvienas iš $2 \mathrm{KP}$ turèjo turèti po bateriją, o Mokomoji baterija - 4 patrankas ir 2 haubicas. Šarvuotụjų traukinių batalioną sudare 3 traukiniai: visuose buvo po 2 platformas su 2 pabūklais, taigi iš viso 6 lauko patrankos ir 6 haubicos. Zenitinę artileriją turèjo sudaryti 3 baterijos - 12 pabūklų, 4-asis AP - likti kariuomenès rezerve vado žinioje su turima ginkluote. Žr.: Projektas ir planas artileriją apginkluoti. LCVA, f. 1373, ap. 1, b. 128, 1. 63-66.
} 
rijos sviedinių poreiki paaiškina planai pirkti naujų modelių pabūklų, o jiems reikejjo naujų sviedinių, be to, kai kuriems turimiems pabūklams trūko amunicijos. Planuota pirkti ìvairios artilerijos ginkluotès: 20 $83,5 \mathrm{~mm}$ Škoda $1919 \mathrm{~m}$. patrankų, 19 - 114,3 mm haubicų, 12 - $105 \mathrm{~mm}$ prancūziškų $1913 \mathrm{~m}$. pabūklų, 12 - 76,5 mm Škoda $19 \mathrm{~m}$. zenitinių pabūklų, 48 - Erhardo, 37-75 mm pabūklus ${ }^{102}$. Be to, numatyta apginkluoti ir vieną rezervinę PD ir tam skirti apie $10 \mathrm{mln}$. Lt. Kadangi iš istoriografijos ir gen. št. plk. ltn. K. Škirpos planų žinoma, kad karo atveju būtų siekiama suformuoti $6 \mathrm{PD}$, buvo parengtas planas trijų rezervinių PD artilerijai ìsigyti ir tam numatyta $56,4 \mathrm{mln}$. Lt suma, už kurią norèta pirkti 138 pabūklus ( 48 - 83,5 mm, $24-114,3 \mathrm{~mm}, 12$ - $105 \mathrm{~mm}, 54-37-75 \mathrm{~mm}$ ) ir 127200 sviedinių ${ }^{103} .1926 \mathrm{~m}$. Artilerijos inspekcijos vyriausybei pateiktas apginklavimo planas nebuvo nei priimtas, nei atmestas ${ }^{104}$.

1926 m. rugpjūtị, siekiant palengvinti kareivių rengimą ir artilerijos pabūklų priežiūrą bei tiekimą, buvo suvienodinta AP ginkluotè. 2-ojo AP 2-5-oji baterijos buvo ginkluotos $76,2 \mathrm{~mm}$ patrankomis, 1-oji haubicų baterija - $105 \mathrm{~mm}$ haubicomis. Pulkas stovejjo Kèdainiuose, išskyrus 4-ąją bateriją, kuri buvo Klaipėdoje. 3-iojo AP, stovejjusio Kaune, 1-oji, 6-oji, 9-oji ir 10-oji baterijos buvo ginkluotos $77 \mathrm{~mm}$ patrankomis, 2-oji haubicų baterija - $105 \mathrm{~mm}$ haubicomis, 4-ojo AP 7-oji baterija $83,8 \mathrm{~mm}$, o 11-oji - $77 \mathrm{~mm}$ patrankomis, 1-oji ir 2-oji sunkiosios artilerijos baterijos - $127 \mathrm{~mm}$ pabūklais. 4-asis AP stovejo Vilkaviškyje, o jo 11-oji baterija - Alytuje. Visi pakeitimai turèjo būti igyvendinti $1926 \mathrm{~m}$. rugsejo $1-5 \mathrm{~d} .{ }^{105}$

\footnotetext{
102 Pirmaeilèms 3-ms divizijoms pabūklams ir sviediniams ịsigyti. LCVA, f. 1373, ap. 1, b. $128,1.68$.

${ }^{103}$ Antraeilis 3 divizijų apginklavimo projektas ir planas. LCVA, f. 1373, ap. 1, b. 128, 1. 67. ${ }^{104}$ Artilerijos viršininko 1929 m. gegužès 7 d. raštas. LCVA, f. 1373, ap. 1, b. 176, 1. 14 . ${ }^{105}$ Vyriausiojo kariuomenès štabo 1926 m. rugpjūčio 18 d. įsakymas. LCVA, f. 1373, ap. 1, b. $128,1.248$.
} 
Lietuvos kariuomenès artilerijos pabūklai 1919-1940 m.

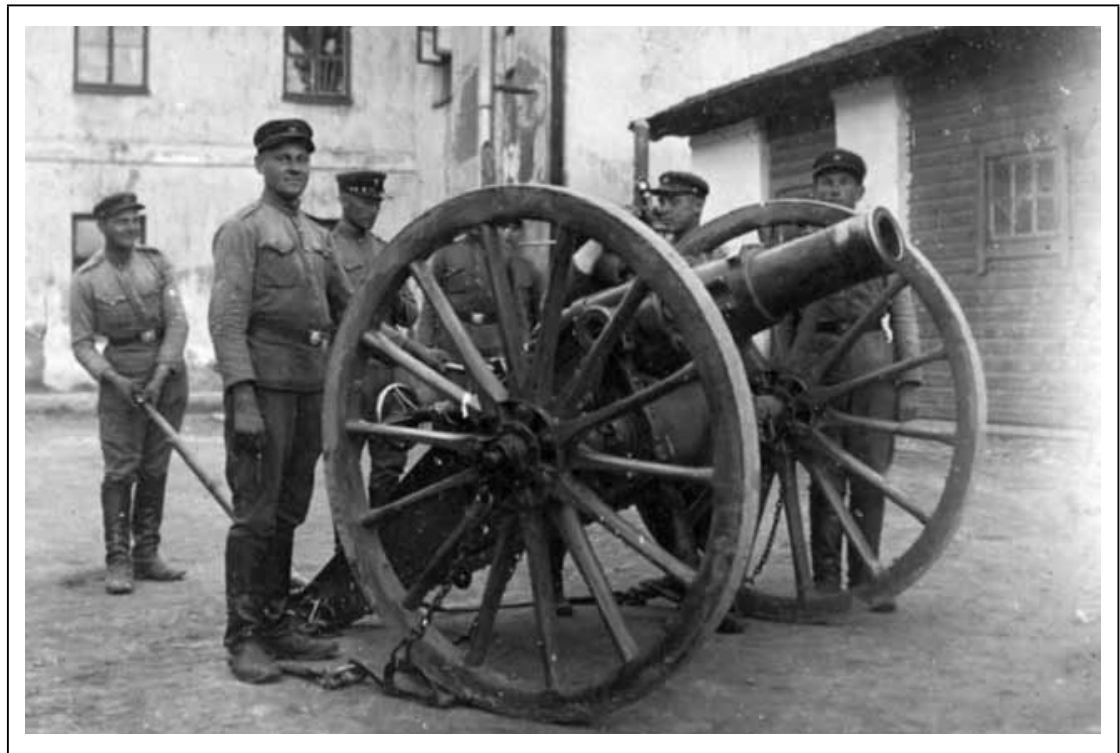

$127 \mathrm{~mm}$ haubica Vickers-Armstrong (D. Britanija) ir jos komanda (asmenines Simono Turausko kolekcijos nuotrauka)

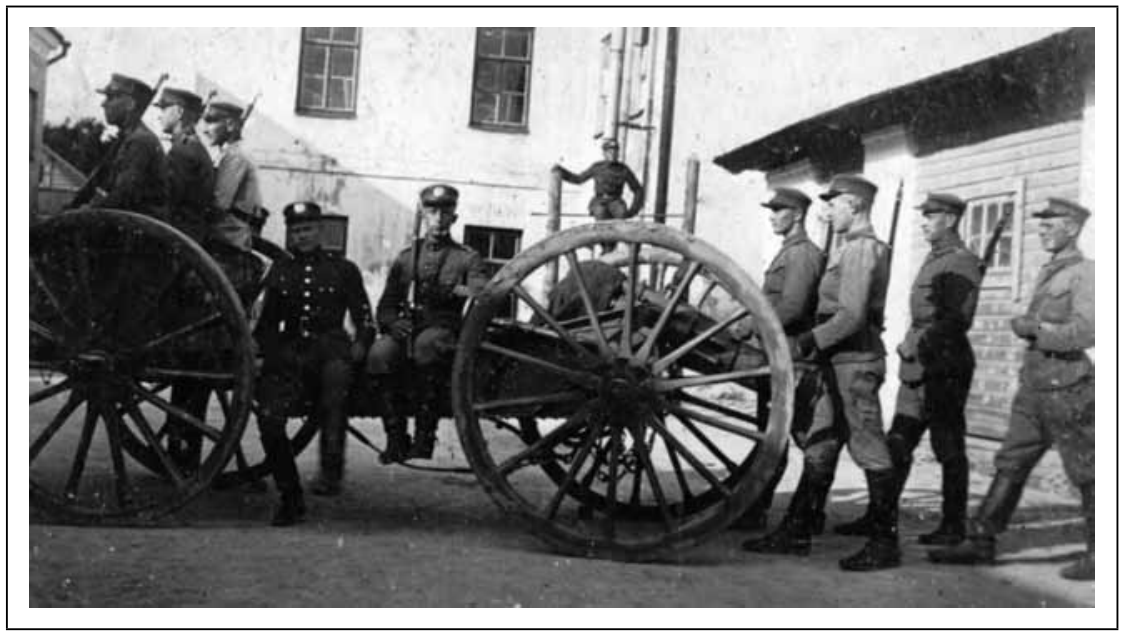

$127 \mathrm{~mm}$ haubica Vickers-Armstrong (D. Britanija) žygio padètyje su pirmagaliu (asmeninès Simono Turausko kolekcijos nuotrauka) 
1927-1928 m. Lietuvoje buvo svarstoma galimybè ginklų kariuomenei issigyti D. Britanijoje. Britų kompanija Vickers-Armstrong Ltd. konkuravo su čekais dèl 1500 lengvųjų kulkosvaidžių užsakymo. Lietuvos ekspertai, jauni karininkai, siūlè pirkti čekiškus ginklus, o politikai - Prezidentas Antanas Smetona, Ministras Pirmininkas Augustinas Voldemaras, krašto apsaugos ministras plk. Teodoras Daukantas - vadovavosi politiniais sumetimais ir buvo linkę tai daryti D. Britanijoje. Dilema išsisprendè poligone, kai sprogo britų kulkosvaidis ir sužalojo Lietuvos karị. Tad užsakymą tiekti kulkosvaidžius gavo čekai. Tačiau savo ruožtu firma Messrs Vickers-Amstrong užsitikrino $883,8 \mathrm{~mm}$ pabūklų užsakymą.

1928 m. Vickers kvietimu ì Londoną nuvyko dvi Lietuvos karininkų delegacijos, ginklų pirkimo klausimu šiame mieste lankèsi ir plk. T. Daukantas. Planuota įsigyti aviacijos kulkosvaidžių, priešlèktuvinių ginklų, lengvụjų tankų ir šarvuočių už 100000 svarų sterlingų ${ }^{106}$, apie $4,9 \mathrm{mln}$. $\mathrm{Lt}^{107}$. Tai vèliau ir buvo padaryta: Lietuva minètoje firmoje issigijo 32 lengvuosius tankus, $975 \mathrm{~mm}$ priešlèktuvinius pabūklus ir kt.

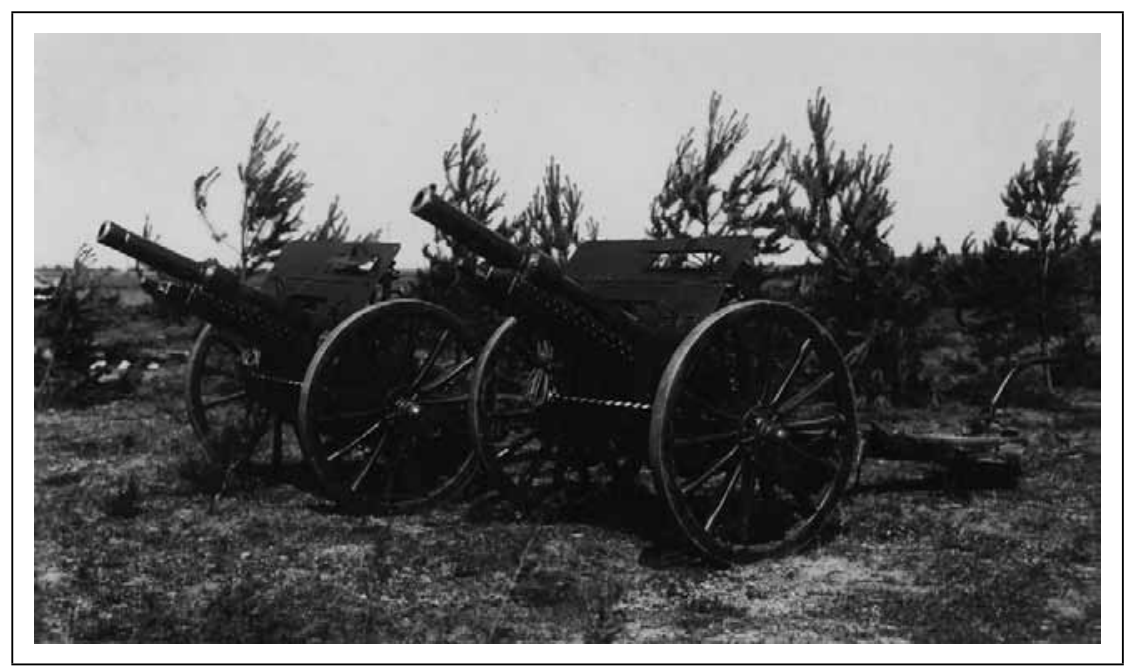

Dvi $84 \mathrm{~mm}$ patrankos Vickers MkIV (D. Britanija) poligone (asmeninés Algirdo Abaravičiaus kolekcijos nuotrauka)

106 Žalys V. Lietuvos diplomatijos istorija (1925-1940). T. 1. Vilnius, 2007, p. 449-450. ${ }^{107} 1928$ m. 1 D. Britanijos svaras sterlingas kainavo apie 49 Lt: Statistikos biuletenis. Kaunas, 1928, Nr. 12, p. 21. 
Greičiausiai ginklų pirkimas užtruko dèl pasaulinès krizès (1929-1933) ir vyko tik 1934-1935 m. Užsakyti angliški 83,8 mm Mk IV pabūklai 1929 m. gegužès mèn. jau buvo Lietuvoje, nes $7 \mathrm{~d}$. Artilerijos viršininkas nurode 4-ojo AP vadui iš Artilerijos tiekimo skyriaus paimti 4 naujus angliškus pabūklus ${ }^{108}$.

1929 m. sausio 1 d. kariuomenė turejjo šių kalibrų pabūklų: 26 77 mm, 10 - 105 mm vokiškų, 19 - 76,2 mm rusiškų, 12 - 127 mm, 4 83,8 mm Mk II. angliškas, 16 - 75 mm, 2 - 155 mm C.S. Mod. 1917 m. prancūziškas, 5 - 57 mm rusiškas ( 3 iš jų buvo Karo muziejuje) kaponierių patrankas, 2 - $37 \mathrm{~mm}$ zenitinius pabūklus ${ }^{109} .1929 \mathrm{~m}$. balandžio 1 d. ataskaitoje minimi 3 vokiški 77 mm 1896 m. pabūklai, todèl nurodytas $77 \mathrm{~mm}$ patrankų skaičius - 29 vnt. ${ }^{110} 1929 \mathrm{~m}$. liepos 1 d. užfiksuota $1283,8 \mathrm{~mm}$ patrankų ( 8 - naujos), 2 vokiškos $77 \mathrm{~mm}$ patrankos stovejo Karo muziejuje ${ }^{111}$. $1929 \mathrm{~m}$. liepos $1 \mathrm{~d}$. kariuomenès ginkluotèje buvo 31 minosvaidis: 10 - daliniuose (5-ajame, 9-ajame PP, Karo mokykloje ir Aukštuosiuose karininkų kursuose), 13 - tinkamų naudoti ir 8 - sugedę (sandèliuose) ${ }^{112}$. Iš viso kariuomenè turèjo 121 ịvairių rūšių artilerijos pabūklą, tačiau apie 15 netiko kautynems arba buvo menkos kovinès vertès. Artilerijos inspekcija konstatavo, kad 21 patrankos (12$76,2 \mathrm{~mm}, 6$ - $77 \mathrm{~mm} 1916 \mathrm{~m}$., 3 - $77 \mathrm{~mm} 1896 \mathrm{~m}$.) ir 5 haubicu (105 mm 1916 m.) vamzdžiai išdilę ir būtina juos keisti ${ }^{113}$. Karo atveju kariuomenei (3 PD) reikèjo 178 pabūklų (68 lauko patrankų, 32 haubicų, 12 sunkiųjų pabūklų, 12 zenitinių patrankų ir 54 péstininkų patrankų), o tuo metu

\footnotetext{
${ }^{108}$ Artilerijos viršininko 1929 m. gegužès 7 d. įsakymas. LCVA, f. 1373, ap. 1, b. 176, 1. 18. 109 Žinios apie ginklų skaičių Lietuvos kariuomenèje ir artilerijos sandèliuose (atsargoj) 1929 m. sausio 1 d. LCVA, f. 929, ap. 3, b. 655, 1. 72.

110 Žinios apie ginklų skaičių Lietuvos kariuomenèje ir artilerijos sandèliuose (atsargoj) 1929 m. balandžio 1 d. LCVA, f. 929, ap. 3, b. 655, 1. 77.

111 Žinios apie ginklų skaičių Lietuvos kariuomenèje ir artilerijos sandèliuose (atsargoj) 1929 m. liepos 1 d. LCVA, f. 929, ap. 3, b. 655, 1. 82.

$11277 \mathrm{~mm} 2$ tinkami ir 1 sugedęs sandèliuose, 5 daliniuose, $170 \mathrm{~mm} 8$ tinkami ir 7 sugedę sandèliuose, 4 daliniuose, $250 \mathrm{~mm} 3$ tinkami sandèliuose ir 1 Karo mokykloje. Žr.: Žinios apie minosvaidžių stovị 1929 m. liepos 8 d. LCVA, f. 929, ap. 3, b. 655, l. 57.

${ }^{113}$ Artilerijos inspekcija 1926 m. gegužès 10 d. tiekimo viršininkui. LCVA, f. 1373, ap. 1, b. $128,1.57$.
} 
daliniuose buvo 67 pabūklai114 (48 patrankos, 13 haubicų ir 6 pèstininkų patrankos) ir 173458 sviediniai (127 973 - lauko patrankų, 42035 - haubicų, 3450 - péstininkų pabūklų) ${ }^{115}$. Anot Algimanto Liekio, $1932 \mathrm{~m}$. Lietuva Prancūzijoje įsigijo $75 \mathrm{~mm}$ lauko pabūklų ir jų sviedinių ${ }^{116}$. Galima spèti, kad Lietuva tuo metu gavo 20 šių pabūklų, nors tai patvirtinančių archyvinių dokumentų mums aptikti nepavyko, o ši pabūklų skaičių gavome aritmetiniu būdu ${ }^{117}$.

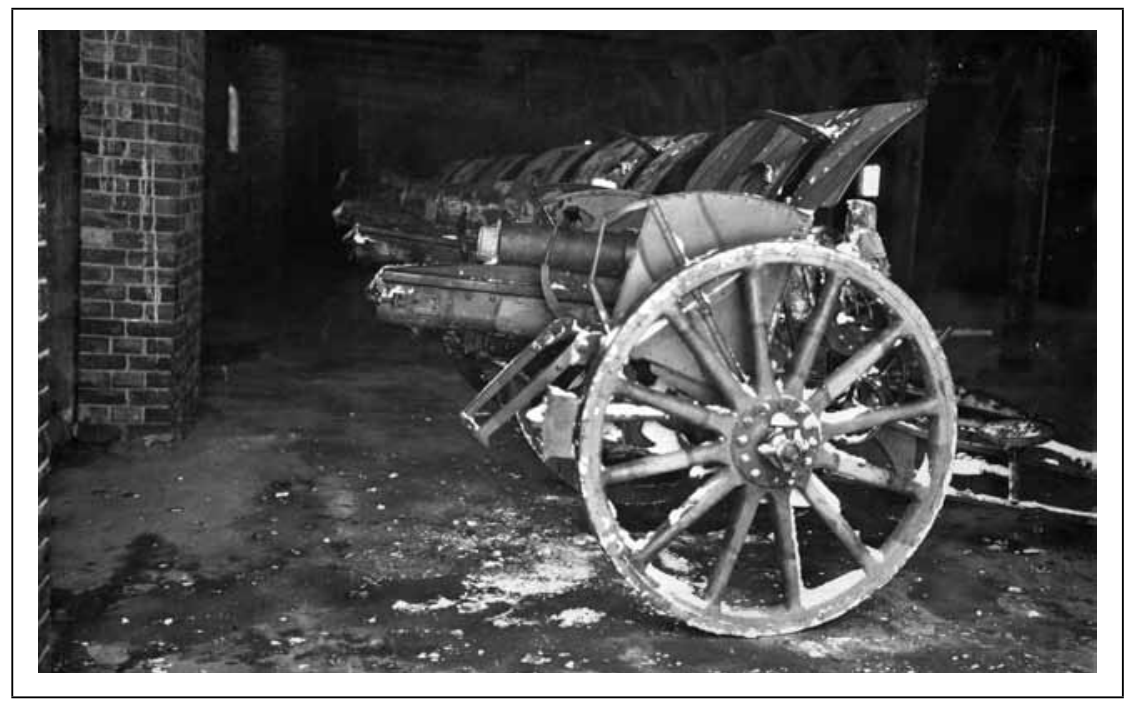

$105 \mathrm{~mm}$ 98/09 m. lauko haubicos (Vokietija), paimtos iš bermontininkų, artilerijos sandèlyje. $1920 \mathrm{~m}$. (VDKM)

\footnotetext{
${ }^{114}$ Lengvosios lauko patrankos: 14 - 75 mm 1897 m., 14 - 77 mm 16 m., 16 - 76,2 mm 1902 m., 4 - 83,8 mm 1904 m. Haubicos: 105 mm 1898/09 m., 127 mm 1895 m. Pèstininkų pabūklai: 6 - 77 mm minosvaidžiai. Žr.: Pirmaeilèms 3-ms divizijoms pabūklams ir sviediniams įsigyti, 1926 m. LCVA, f. 1373, ap. 1, b. 128, 1. 68.

${ }^{115}$ Siūlyta ịsigyti dar 111 pabūklų ir 118300 sviedinių už 46,781 mln. Lt. Žr.: Projektas ir planas artileriją apginkluoti, 1926 m. LCVA, f. 1373, ap. 1, b. 128, 1. 63-66.

${ }^{116}$ Liekis A. Lietuviu karyba ir ginkluotè (iki 1940 m.). Vilnius, 2002, p. 638. Galima spèti, kad minètas faktas paimtas iš jau aptarto S. Biručio straipsnio, kuriame teigiama, jog 1932 m. Lietuva ịsigijo kelias baterijas prancūziškų $75 \mathrm{~mm}$ lauko patrankų. Žr.: Birutis S. Lietuvos kariuomenès ginklavimasis // Karys, 1991, Nr. 5, p. 260.

${ }^{117} 1929 \mathrm{~m}$. Lietuvos kariuomenè turejjo $1675 \mathrm{~mm}$ patrankų, o $1934 \mathrm{~m}$. jau 36 (1 lentelè), taigi skirtumas - 20 vnt.
} 
1934 m. Lietuva primygtinai SSRS prašè parduoti ginklų, tačiau jos valdžia, numanydama, kad tokia prolietuviška laikysena gali tapti kliūtimi su Lenkija susitarti ir pasirašyti nepuolimo sutartị (1934 m. gegužès 5 d.) sprendimą vilkino ${ }^{118}$. Pats Antanas Smetona deklaravo interesą plètoti santykius su Sovietų Sąjunga ir tai ne kartą buvo pareiškęs sovietų pasiuntiniui Michailui Karskiui. Prezidentas pabrèžè, kad Lietuvai „reikalinga SSSR parama - politinè, ekonominè ir karinë“119. Buvęs Ginklavimo valdybos viršininko padejejjas inž. plk. Stasys Birutis pažymėjo, kad $1934 \mathrm{~m}$. buvo galimybė SSRS ịsigyti naujo modelio 76,2 mm lauko pabūklų, ir jis vyko ị Maskvą apžiūrèti ginklų, smulkiau sužinoti pirkimo sąlygų. Tačiau SSRS pabūklų gamyba ir brèžiniai buvo griežtai saugomos paslaptys, todèl juos rodyti atsisakyta bei pasiūlyta tiesiog pasitikèti ir nekeliant jokių sąlygų pageidaujamų ginklų ịsigyti. Po ilgų derybų buvo surengtas parodomasis pabūklų šaudymas poligone prie Leningrado, tačiau jị leido stebėti tik kelių šimtų metrų atstumu per restorano vagono

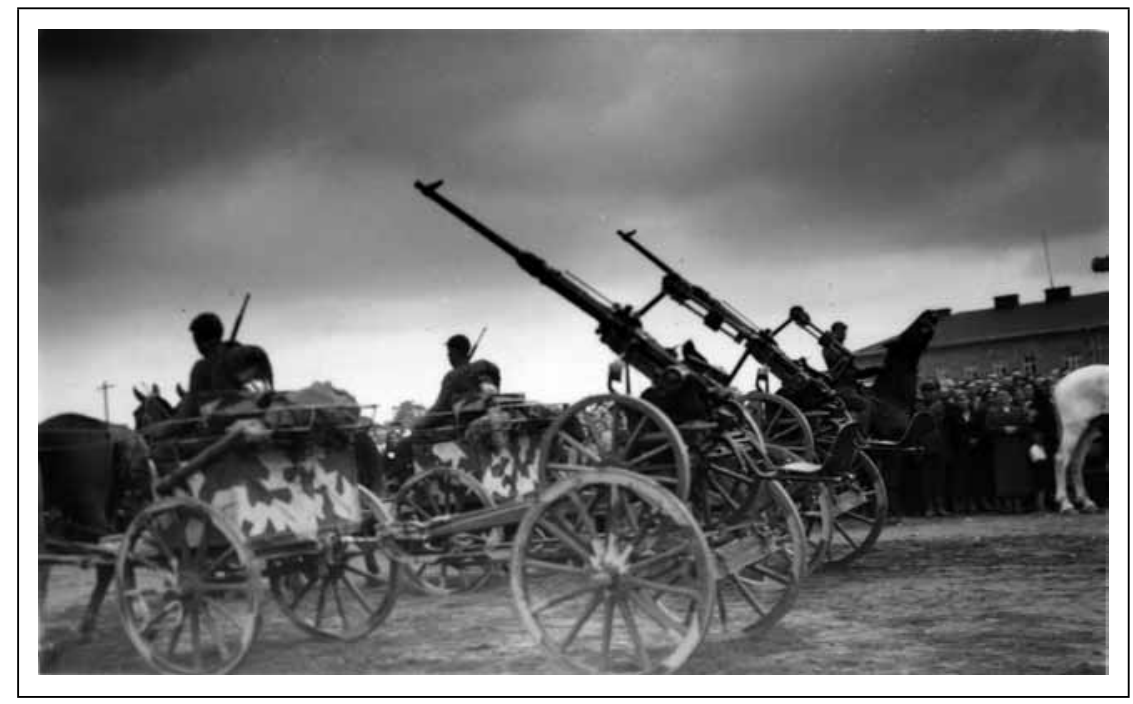

Lietuvos kariuomenès 1-ojo pėstininkų pulko Oerlikon automatinių pabūklų būrys parado metu. $1938 \mathrm{~m}$. Fotografas nenurodytas (LCVA)

${ }^{118}$ Zubkova J. Pabaltijys ir Kremlius 1940-1953. Vilnius, 2010, p. 29.

119 Ten pat, p. 34 . 


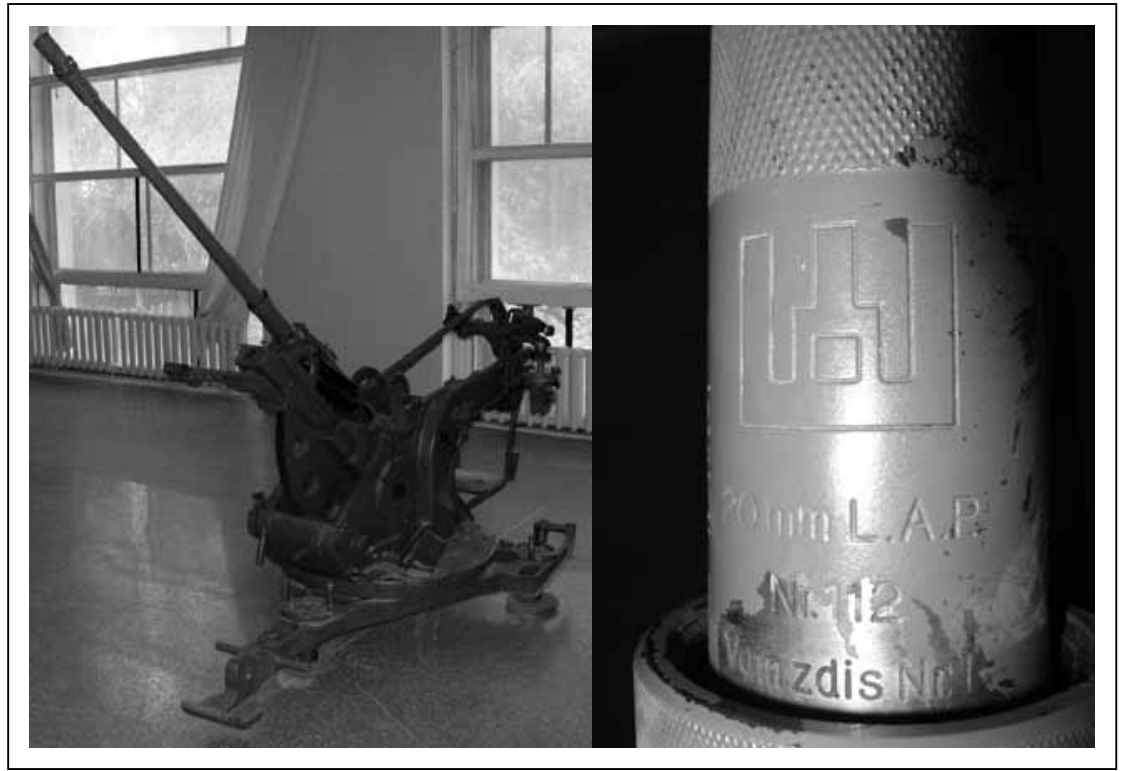

Lietuvos kariuomenès 20 mm LAP (Flak 30) pabūklas. RF Centrinis Ginkluotuju Pajegu muziejus (fot. Viktor Kolomijec)

langą. Dèl minètų priežasčių tuokart Lietuva atsisakè iš SSRS pirkti artilerijos pabūklų, tik užsakè 3000 kardų kavalerijai ${ }^{120}$. Plk. S. Biručio minimu laikotarpiu SSRS buvo gaminamos labai mažai nuo senųų 1902 m. patrankų besiskiriančios 1902/30 m. pavyzdžio patrankos, o naujųjų, ne itin vykusių 1933 m. pavyzdžio, patrankų buvo pagaminta vos $200^{121}$. Galbūt viena tokio SSRS pareigūnų elgesio priežasčių buvo ir tai, kad $1934 \mathrm{~m}$. jokių iš esmès naujo modelio 76,2 mm patrankų paprasčiausiai neturèta.

1934 m. birželio 16 d. Kaune buvo pasirašyta sutartis su Vickers-Armstrong Ltd. dèl $975 \mathrm{~mm}$ priešlèktuvinių pabūklų ir 27000 sviedinių pirkimo. Pirmoji baterija ị Klaipèdą turèjo būti pristatyta $1935 \mathrm{~m}$. sausio 2 d., antroji - iki vasario $17 \mathrm{~d}$., trečioji - balandžio 1d. ${ }^{122}$ Automatinius Oerlikon pabūklus Lietuvos kariuomenè ịsigyti nusprendè taip pat dar iki 1934 m.,

\footnotetext{
${ }^{120}$ Birutis S. Lietuvos kariuomenès ginklavimasis // Karys, 1991, Nr. 5, p. 260.

${ }^{121}$ Широкорад А. Энииклопедия отечественной артиллерии. Минск, 2006 c. $459-463$.

${ }^{122}$ Statkus V. Lietuvos ginkluotos pajégos 1918-1940 m. Chicago, 1986, p. 127-128.
} 
kai kariuomenei vadovavo gen. Itn. Petras Kubiliūnas ${ }^{123}$. Šveicarijos firmoje Werkzeugmaschinenfabrik Oerlikon Buehrle \& Co. Lietuva įsigijo $20 \mathrm{~mm}$ Oerlikon 1 II a S modelio pabūklų. Firmos duomenimis, 1934 m. birželio-gruodžio mèn. ị Lietuvą buvo pristatyti 156 pabūklai, 6 iš jų - skirti montuoti šarvuočiuose ${ }^{124}$. Tai patvirtina ir archyviniai dokumentai, tačiau minima, kad kariuomenè naudojo Oerlikon JLaS tipo pabūklus. Jų turèta 150: priešlèktuvinei apsaugai - 36, 96 - péstininkų pulkams (16 PP - po 6 pabūklus, kiekviename šaulių batalione - po 2), KP turèjo turèti po 2 pabūklus (iš viso 6), Karo mokykla - 2, mokomasis karo laivas Prezidentas Smetona - 2; šarvuotiesiems traukiniams apginkluoti buvo numatyta skirti po 2 - iš viso 4, Ginklavimo valdybai - taip pat $4^{125}$. Tačiau šarvuotieji traukiniai buvo išformuoti, matyt, net nespèję gauti Oerlikon pabūklų.

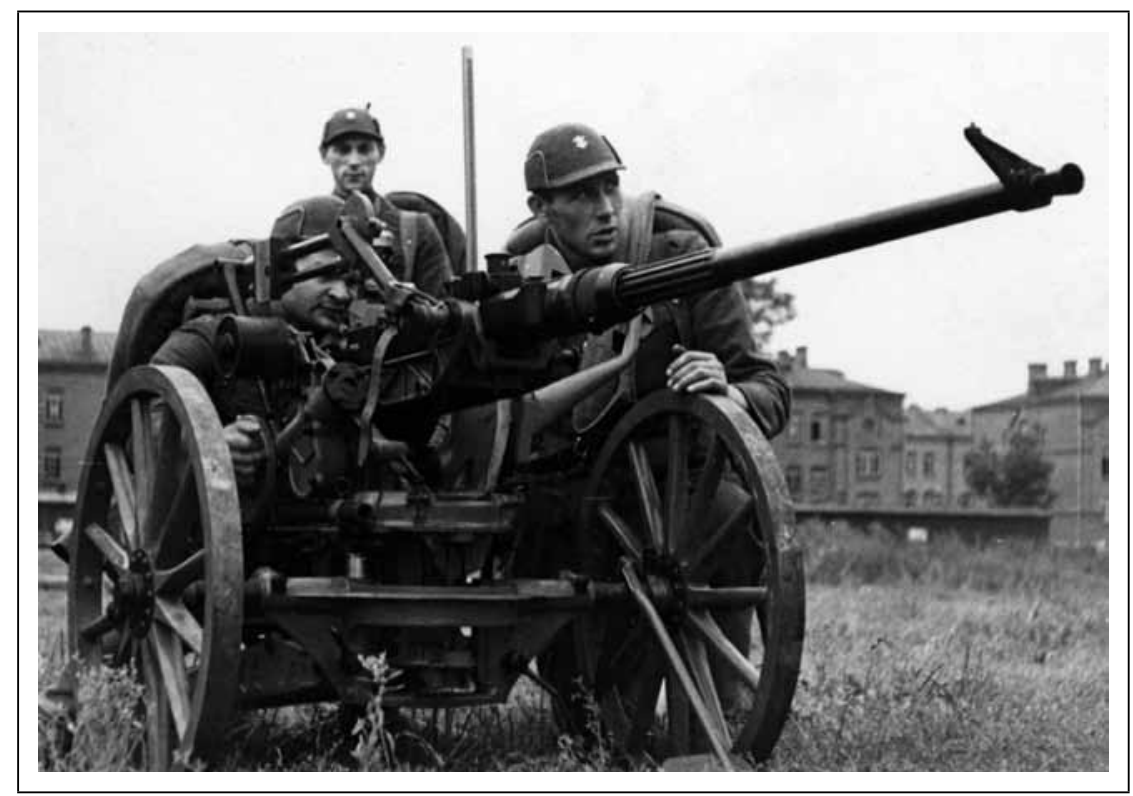

Lietuvos kariuomenès 6-ojo pėstininkų pulko kariai prie automatinio Oerlikon pabūklo. Fotografas Julius Miežlaiškis (LCVA)

${ }^{123}$ Raštikis S. Lietuvos likimo keliais. T. 4. Kaunas, 1996, p. 266.

${ }^{124}$ Statkus V. Lietuvos ginkluotos pajegos 1918-1940 m. Chicago, 1986, p. 534.

${ }^{125}$ Ginklavimo viršininko 1935 m. sausio 26 d. raportas. LCVA, f. 3, ap. 1, b. 262, 1. 29. 
$1934 \mathrm{~m}$. liepos $1 \mathrm{~d}$. Lietuvos kariuomenè turëjo ịvairių pabūklų: 19 - rusiškų 76,2 mm Putilov 1902 m., 22 - 77 mm 1916 m. vokiškas, 5 - 77 mm 1896 m., 36 - $75 \mathrm{~mm}$ Schneider $1897 \mathrm{~m}$. prancūziškas, 8 naujas, neseniai pirktas $83,8 \mathrm{~mm}$ Mk IV, 4 - senas $83,8 \mathrm{~mm}$ Mk II an-

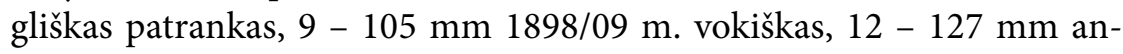
gliškų, 2 - $155 \mathrm{~mm}$ prancūziškas haubicas, $1-105 \mathrm{~mm}$ 10.K.17. vokišką patranką, 5 - $57 \mathrm{~mm}$ kaponierių, $3-37 \mathrm{~mm}$ zenitines, $3-37 \mathrm{~mm}$ tankų patrankas ${ }^{126}$. Be to, $1934 \mathrm{~m}$. spalio $25 \mathrm{~d}$. jau turejo 50 automatinių $20 \mathrm{~mm}$ Oerlikon pabūklų ir 26 senus minosvaidžius ${ }^{127}$. $1934 \mathrm{~m}$. iš viso Lietuvos kariuomenès artilerijos ginkluotę sudarè 205 ịvairių rūšių pabūklai.

Dalis artilerijos pabūklų buvo naudojami šarvuotiesiems traukiniams apginkluoti. $1923 \mathrm{~m}$. kovo 3 d. duomenimis, šarvuotasis traukinys Gediminas buvo ginkluotas 4 patrankomis: $2-75 \mathrm{~mm}$ ir $2-57 \mathrm{~mm}$, Kęstutis $277 \mathrm{~mm}$ patrankomis, Algirdas - $2105 \mathrm{~mm}$ haubicomis. Tačiau $1927 \mathrm{~m}$. rugsèjo 16 d., išformavus Šarvuotųjų traukinių batalioną, kariuomenèje liko tik vienas šarvuotasis traukinys Gediminas, $1935 \mathrm{~m}$. rugpjūčio $14 \mathrm{~d}$. ir jo buvo atsisakyta ${ }^{128}$.

1926 m. kovo 26 d. Artilerijos inspekcija konstatavo, kad būtina „remontuoti rusų patrankoms vamzdžius - pakeisti branduolio tūtas užsienyje“. Kiek truks ir kainuos remonto darbai, nežinota, bet nurodyta daliniams skirti kitus pabūklus ${ }^{129}$. Siūlyta derètis su Olandijos bendrove dèl 24 pabūklų vamzdžių remonto ${ }^{130}$. Kadangi turimų rusiškų $76,2 \mathrm{~mm}$ pabūklų vamzdžiai buvo labai susidèveję, o galimybiu pakeisti ginkluotę nebuvo, anot plk. S. Biručio, visi šie pabūklai buvo išsiųsti $\mathfrak{i}$ Bofors dirbtuves Švedijoje „pervamzdžiuoti“. Be to, jiems buvo sukonstruoti nauji sviediniai. Visa tai leido minètų pabūklų šūvio nuotolị padidinti iki $11 \mathrm{~km}^{131}$. Pastarojo fakto galutinai negalime nei patvirtinti, nei paneigti, tačiau $1927 \mathrm{~m}$. Artilerijos

\footnotetext{
126 Žinios 1934 m. liepos 1 d. LCVA, f. 929, ap. 3, b. 889, 1. 4.

${ }^{127}$ Kariuomenès apsiginklavimo stovis 1934 m. spalio 25 d. LCVA, f. 929, ap. 3, b. 889, 1. 3 .

${ }^{128}$ Pociūnas A. Šarvuoti traukiniai Lietuvos kariuomeneje // Karys, 1994, Nr. 5, p. 23.

${ }^{129}$ Artilerijos inspekcijos 1926 m. kovo 26 d. raportas Tiekimo viršininkui. LCVA, f. 1373, ap. 1, b. 128, 1. 53 .

${ }^{130}$ Artilerijos inspekcijos $1926 \mathrm{~m}$. gegužès $10 \mathrm{~d}$. raportas Tiekimo viršininkui. LCVA, f. 1373 , ap. 1, b. $128,1.57$.
}

${ }^{131}$ Birutis S. Lietuvos kariuomenès ginklavimasis // Karys, 1991, Nr. 5, p. 260. 
vadovèlyje ${ }^{132}$ duomenų apie 76,2 mm kalibro sviedinius, kuriais būtų galima šaudyti iki $11 \mathrm{~km}$ atstumu, nèra. $1939 \mathrm{~m}$. Artilerijos statute nurodyti „s“ tipo sviediniai, kuriais iš 76,2 mm $1902 \mathrm{~m}$. patrankos buvo galima šaudyti didžiausiu $11,3 \mathrm{~km}$ atstumu ir kurie savo forma gerokai skyrèsi nuo kitu $76,2 \mathrm{~mm}$ kalibro sviedinių ${ }^{133}$. Pažymètina, kad $1938 \mathrm{~m}$. vyko raitosios artilerijos, ginkluotos 76,2 mm pabūklais, mokymai poligone. Kavalerijos viršininkas savo raporte artilerijos inspektoriui rašè, kad: „1) šrapneliai nevaržoma ugnimi (karteče) šaudant veikia daugumoje blogai, šaudant oriniai labai didelè sklaida; 2) daugumos šrapnelių degtuvų žiedai sukasi nepaprastai sunkiai - vienas degtuvinis negali pasukti, o pavartojus jẻgą lūžta raktas; 3) granatų apie $40 \%$ visai nesprogsta." ${ }^{134}$ Taigi šaudymo poligone rezultatai nebuvo džiuginantys, o naujo pavyzdžio sviediniai visai neminimi.

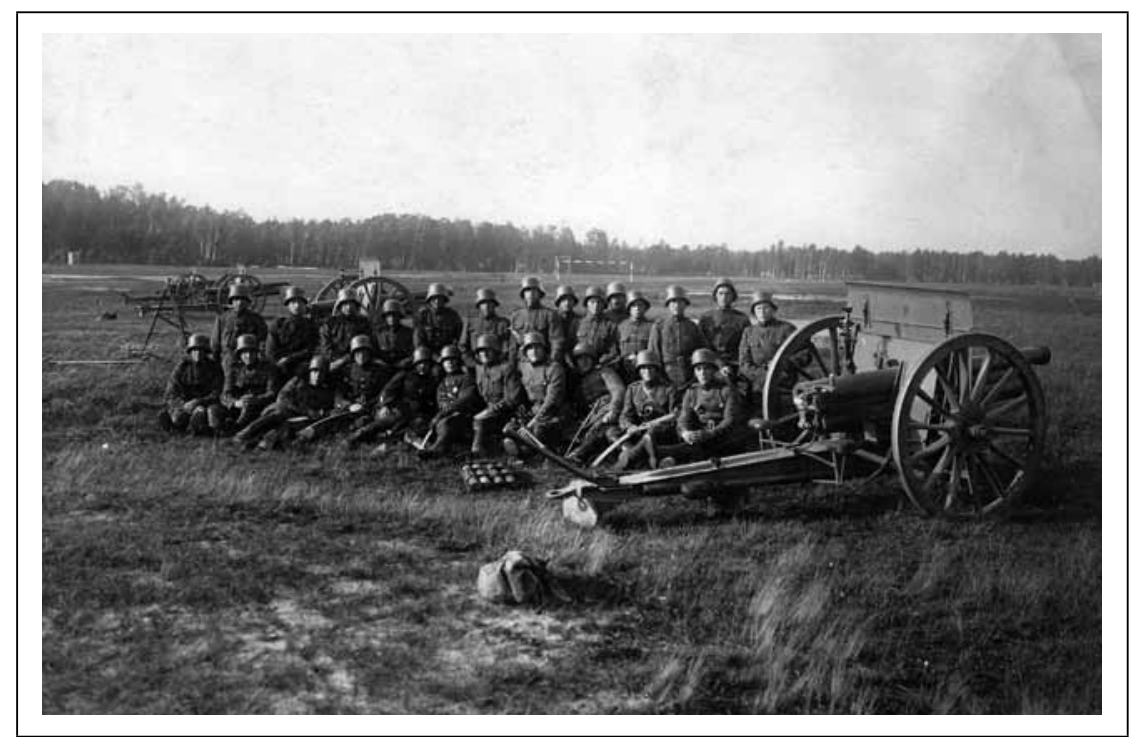

Lietuvos kariuomenès artileristai prie $76,2 \mathrm{~mm} 1902 \mathrm{~m}$. modelio rusiškos lauko patrankos (VDKM)

${ }^{132}$ Bytautas P. Artilerijos vadovèlis. II dalis. Kaunas, 1927, p. 103-104.

${ }^{133}$ Artilerijos statutas. IV dalis. Pabūklai ir šaudmenys. b) $76 \mathrm{~mm} 1902 \mathrm{~m}$. patranka. A-53b. Kaunas, 1939, p. 20, 21, 85, 86.

1341938 m. spalio 14 d. Kavalerijos viršininko raštas Artilerijos inspektoriui. LCVA, f.1373, ap. 1, b. $287,1.28$. 


\section{ARTILERIJOS ATNAUJINIMAS 1935-1940 M.}

$\mathrm{XX}$ a. ketvirtajame dešimtmetyje būtinybè atnaujinti ir praplèsti Lietuvos kariuomenės artilerijos parką buvo akivaizdi, nes nuolatinis ginkluotès stygius neleido išnaudoti viso valstybès mobilizacinio ir galios potencialo. Jau anksčiau minèjome, kad planų stiprinti Lietuvos kariuomenès artilerijos ginkluotę būta dar trečiajame dešimtmetyje, tačiau galimai dèl politinių aplinkybių ir pasaulyje prasidejjusios didžiosios ekonomikos krizès jie nebuvo igyvendinti. Ypatingą pagreitị kariuomenès apginklavimo procesas igavo, kai 1934 m. gen. št. plk. ltn. Stasys Raštikis tapo Lietuvos kariuomenès vadu, o 1935 m. sausio mèn. naujai sukurtoje Gynybos taryboje buvo priimtas Lietuvos kariuomenès reformų planas, kuriam igyvendinti buvo numatyta $175 \mathrm{mln}$. Lt nepaprastųjų išlaidų ${ }^{135}$ : ginkluotei įsigyti (1 diagrama) - 106,5 mln. Lt, daugiau kaip 60 \% skirtų lěšų, artilerijai (3 lentelè) - $52394845 \mathrm{Lt}$, planuojant pirkti 271 ịvairių tipų pabūklą (už 24, $233 \mathrm{mln}$. Lt) ir daugiau kaip 562000 jų sviedinių (už 28,162 mln. Lt) $)^{136}$.

1 diagrama Lietuvos kariuomenès apginklavimo planui igyvendinti skirtos lèšos (\%)

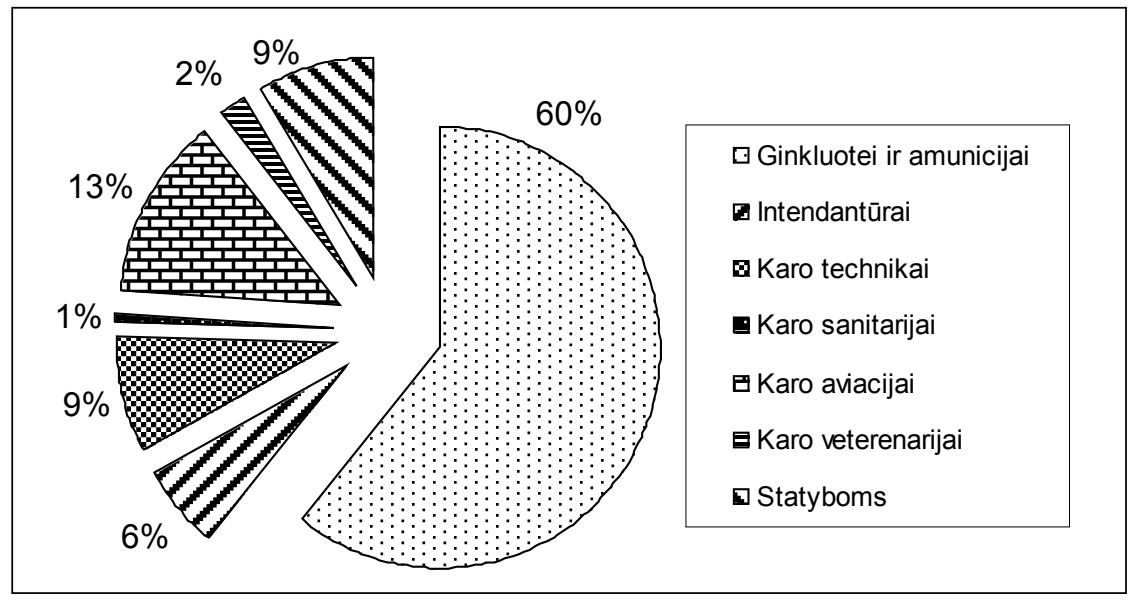

${ }^{135}$ Vaičenonis J. Lietuvos kariuomenès modernizacija (1926-1939) // Darbai ir dienos. T. 21. Kaunas, 2001, p. 157.

${ }^{136}$ 1935-1941 m. ginklavimo planas, 1936 m. kovas. LCVA, f. 929, ap. 9, b. 163, 1. 2-3. 
3 lentele 1935-1941 m. ginklavimo plane numatytų ịsigyti artilerijos pabūklų ir amunicijos sąrašas ${ }^{137}$

\begin{tabular}{|l|c|c|}
\hline \multicolumn{1}{|c|}{ Pavadinimas } & Kiekis & Kaina Lt \\
\hline Sunkiosios haubicos & 12 & 3000000 \\
\hline 75 mm patrankos & 66 & 3960000 \\
\hline Pėstininkų pabūklai (minosvaidžiai) & 100 & 1519845 \\
\hline Pakrančių jūriniai pabūklai & 2 & 1000000 \\
\hline Priešlekktuviniai pabūklai & 9 & 1800000 \\
\hline Sunkiosios patrankos & 12 & 270000 \\
\hline 105 mm lengvosios haubicos & 70 & 10253000 \\
\hline 75 mm priešlèktuviniai sviediniai & 9000 & 180000 \\
\hline 155 mm sunkiųjų haubicų sviediniai & 6000 & 180000 \\
\hline 20 mm sviediniai & 370000 & 7400000 \\
\hline 81,4 mm minosvaidžių minos & 60000 & 2100000 \\
\hline 75 mm artilerijos sviediniai & 80800 & 7272000 \\
\hline 105 mm haubicų sviediniai & 36600 & 5490000 \\
\hline Sunkiųjų patrankų sviediniai & - & 1500000 \\
\hline Pakrančių artilerijos sviediniai & - & 800000 \\
\hline
\end{tabular}

1938 m. gegužès 21 d. apginklavimo planas (galbūt dèl 1938 m. kovo $17 \mathrm{~d}$. Lenkijos pateikto ultimatumo) buvo pakoreguotas ir vien ginklams įsigyti buvo skirta ne anksčiau numatyta suma - 106,5 mln. Lt, o $123,7971 \mathrm{mln}$. Lt (t. y. 17,2971 mln. Lt daugiau). Artilerijos finansavimas pabūklams ir sviediniams pirkti gerokai padidejo, iki 75,4034 mln. Lt, kas sudarė $60,91 \%$ ginkluotei skirtų lèšų (4 lentelè) ${ }^{138}$. Kaip matome susipažinę su naujuoju planu, kariuomenès vadovybė itin susirūpino prieštankine artilerija ir planavo issigyti 310 pabūklų. Palyginę ši planą ir 1939-1940 m. ịsigytos ginkluotès duomenis įsitikinsime, kad jo aklai nesilaikyta: nupirkta 150 zenitinių $20 \mathrm{~mm}$ Flak. 30 pabūklų ir $24105 \mathrm{~mm}$ sunkiosios patrankos, kurių plane nebuvo. 1938 m. spalio 1 d. Karo tary-

137 Ten pat, 1. 2-3.

${ }^{138}$ Papildytas ginklavimo planas, 1938 m. gegužès 21 d. LCVA, f. 929, ap. 9, b. 163, 1. 18-19. 
boje buvo nutarta vietoj anksčiau planuotų 10 priešlèktuvinių $75 \mathrm{~mm}$ pabūklų ịsigyti 12, o prieštankiniams pabūklams pirkti skirti 22,7 mln. Lt $^{139}$.

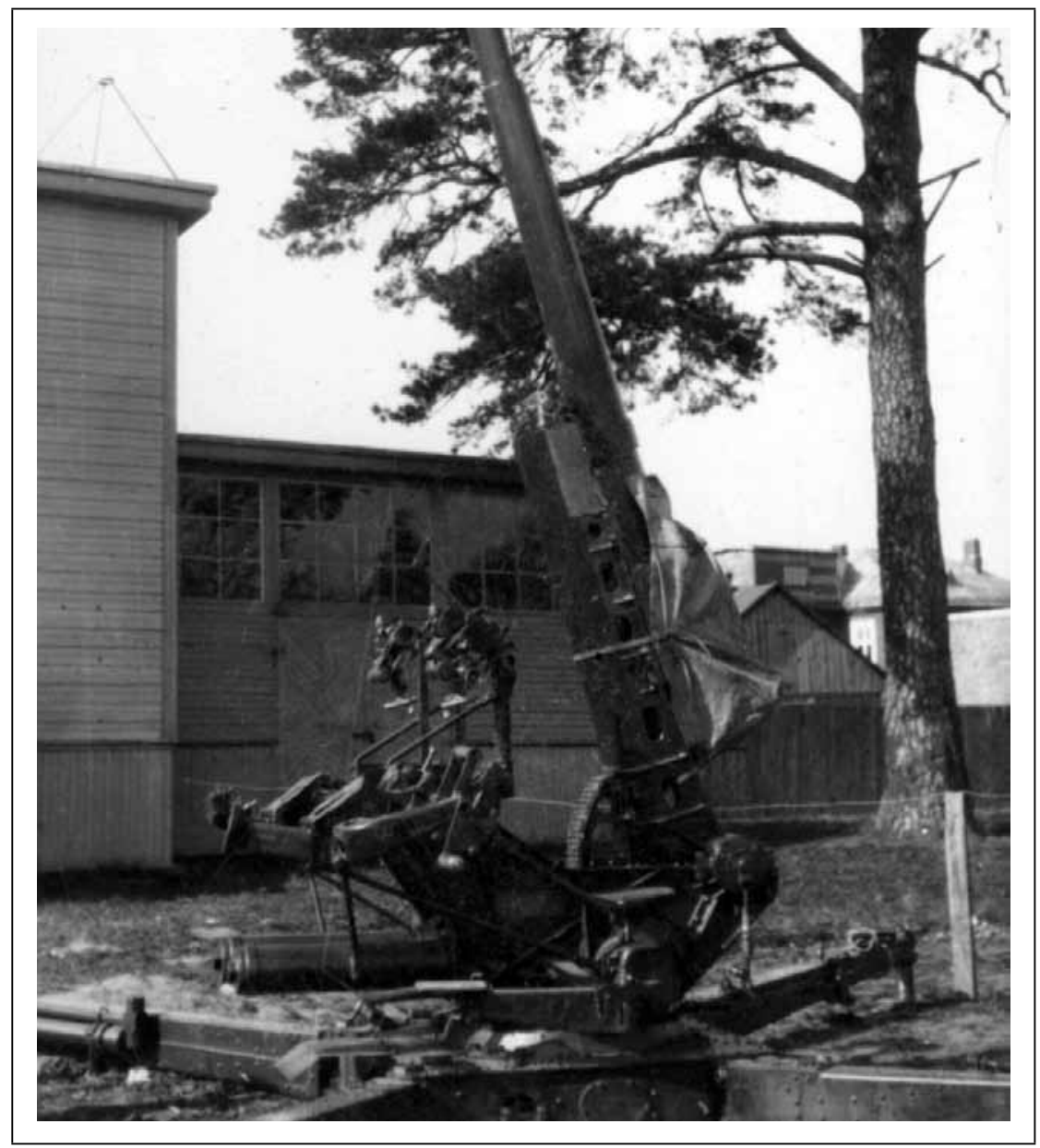

Lietuvos kariuomenès $75 \mathrm{~mm}$ priešlèktuvinis pabūklas

Vickers (D. Britanija) šaudymo pozicijoje. 1936-1937 m. (VDKM)

${ }^{139}$ Kariuomenès septynerių metų ginklavimo planas buvo papildytas skyrus 59,396 mln. Lt. 12 priešlèktuvinių pabūklų ir 3600 sviedinių įsigyti buvo skirta $0,54 \mathrm{mln}$. Lt, $20 \mathrm{~mm}$ šovinių gamybai 3 metams - 7,5 mln. Lt, $2 \mathrm{mln}$. Lt - $105 \mathrm{~mm}$ patrankoms motorizuoti. Žr.: Karo tarybos 1938 m. spalio 1 d. posèdžio protokolas. LCVA, f. 929, ap. 9, b. 163, l. 11-11 a. l. 
4 lentele Papildytame 1935-1941 m. ginklavimo plane numatytų įsigyti artilerijos pabūklų ir amunicijos sąrašas ${ }^{140}$

\begin{tabular}{|c|c|c|}
\hline Pavadinimas & Kiekis & Kaina Lt \\
\hline $20 \mathrm{~mm}$ prieštankiniai pabūklai & 230 & 6900000 \\
\hline $20 \mathrm{~mm}$ sviediniai & 460000 & 6900000 \\
\hline $47 \mathrm{~mm}$ prieštankiniai pabūklai & 80 & 4800000 \\
\hline $47 \mathrm{~mm}$ sviediniai & 48000 & 7600000 \\
\hline $75 \mathrm{~mm}$ patrankos & 36 & \multirow{2}{*}{9212000} \\
\hline $75 \mathrm{~mm}$ artilerijos sviediniai & 80800 & \\
\hline Priešlèktuviniai pabūklai & 10 & 2000000 \\
\hline $75 \mathrm{~mm}$ priešlèktuviniai sviediniai & 5000 & 1000000 \\
\hline $105 \mathrm{~mm}$ haubicos & 120 & \multirow{2}{*}{20250000} \\
\hline $105 \mathrm{~mm}$ haubicu sviediniai & 107600 & \\
\hline $20 \mathrm{~mm}$ sviediniai & 370000 & 7400000 \\
\hline $81,4 \mathrm{~mm}$ minosvaidžiai & 100 & \multirow{2}{*}{3620000} \\
\hline 81,4 mm minosvaidžių minos & 60000 & \\
\hline
\end{tabular}

1936 m. sausio $10 \mathrm{~d}$. Artilerijos inspekcija pasiūlè 12 angliškų 83,8 mm pabūklų išmainyti ị latvių, kurie tokio kalibro pabūklų daugiausiai turèjo, naudojamas rusiškas $76,2 \mathrm{~mm}$ arba vokiškas $77 \mathrm{~mm}$ patrankas, nes dèl pabūklų ịvairovès taikos metu buvo sunkiau mokyti karius, o per karą gaminti ir tiekti amuniciją. Be to, siūlyta $76,2 \mathrm{~mm}$ pabūklų kalibrą, kaip Lenkijoje, pakeisti i $75 \mathrm{~mm}$ ir tokiu būdu padidinti prancūziško kalibro patrankų skaičių. Angliškas $127 \mathrm{~mm}$ ir vokiškas $105 \mathrm{~mm}$ haubicas bei šaudmenis rekomenduota progai pasitaikius parduoti ir už gautus pinigus įsigyti prancūziškų $75 \mathrm{~mm}$ patrankų ${ }^{141}$.

\footnotetext{
${ }^{140}$ Papildytas ginklavimo planas, 1938 m. gegužès 21 d. LCVA, f. 929, ap. 9, b. 163, 1. 18-19. ${ }^{141}$ Artilerijos inspekcijos $1936 \mathrm{~m}$. sausio $10 \mathrm{~d}$. raportas kariuomenès vadui. LCVA, f. 1373 , ap. 1, b. $246,1.1$.
} 


\section{LIETUVOS RESPUBLIKOS KARIUOMENĖ 1918-1940 M.}

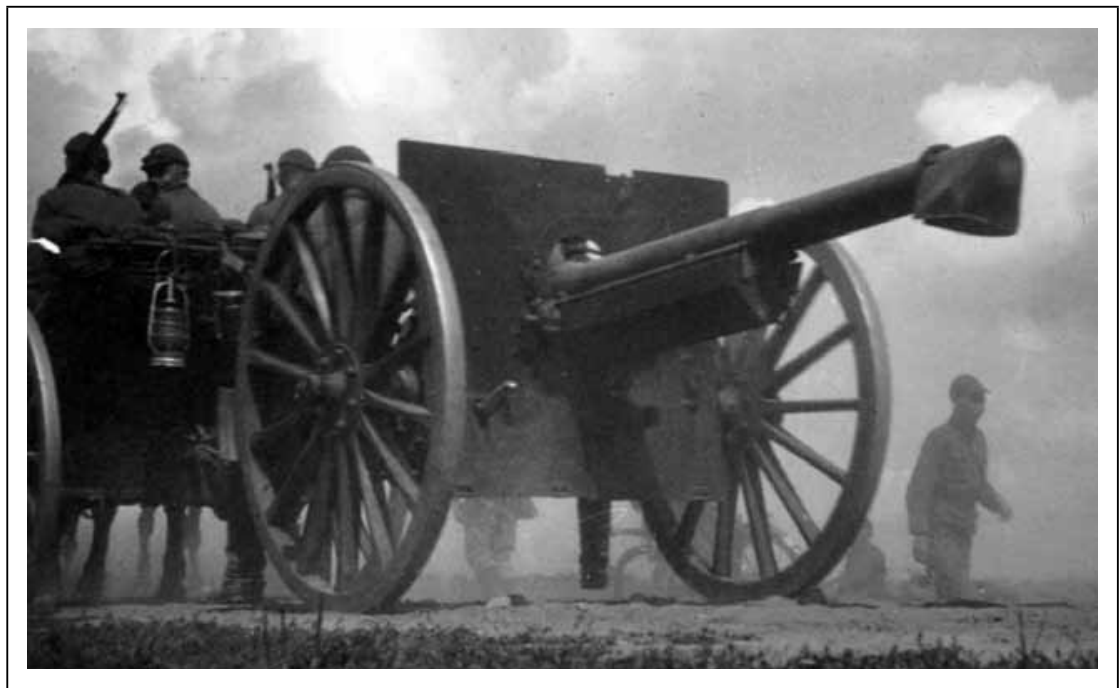

$75 \mathrm{~mm} 1897 \mathrm{~m}$. modelio Schneider patranka (Prancūzija)

Lietuvos kariuomenès parade Kaune. 1938 m. rugsejjo 8 d. (VDKM)

Planus keistis pabūklais su latviais bandyta igyvendinti jau tų pačių metų vasario $6 \mathrm{~d}$. Lietuvos karo atašè Baltijos šalyse gen. št. plk. Boleslovui Jakučiui buvo nurodyta Latvijos karo ministerijoje išsiaiškinti galimybes iškeisti minètus ginklus ${ }^{142}$. Tačiau žinant, kad šie angliški ir rusiški pabūklai kariuomenès ginkluotèje išliko iki pat $1940 \mathrm{~m}$., galima spèti, jog mainai su Latvija neįvyko. $1936 \mathrm{~m}$. pradžioje 1-ojo AP ginkluotę sudarè $75 \mathrm{~mm}$ patrankos ir $1155 \mathrm{~mm}_{\text {haubica }}{ }^{143}$, 2-ojo AP - $1976,2 \mathrm{~mm}$ patrankų ir $8127 \mathrm{~mm}$ haubicos ${ }^{144}, 3$-iasis AP buvo ginkluotas vokiško-

${ }^{142}$ Kariuomenès štabo 1936 m. vasario 6 d. įsakymas. LCVA, f. 1373, ap. 1, b. 246, 1. 10.

${ }^{143}$ 1-ojo AP I AG Ukmergeje ginkluotę sudarè $1175 \mathrm{~mm}$ patrankų (12-asis to paties kalibro pabūklas buvo artilerijos dirbtuvèse Kaune), II AG Panevėžyje - $475 \mathrm{~mm}$ patrankos ir $1155 \mathrm{~mm}$ haubica (antroji to paties kalibro sugadinta haubica buvo Centriniame artilerijos sandèlyje), III AG Kupiškyje - $475 \mathrm{~mm}$ patrankos (dar 4 sugadintos $75 \mathrm{~mm}$ patrankos buvo Karo muziejuje). Žr.: 1-ojo AP 1936 m. sausio 18 d. raportas. LCVA, f. 1373, ap. 1, b. 246, l. 5. ${ }^{144}$ I AG Kèdainiuose ginkluote: 1-oji baterija - $376,2 \mathrm{~mm}, 2$-oji - 4 76,2 $\mathrm{mm}$ patrankos, 3-ioji - $2127 \mathrm{~mm}$ haubicos; II AG Seredžiuje: 4-oji baterija - 4 76,2 mm, 5-oji - 2 76,2 mm patrankos, 6-oji - $3127 \mathrm{~mm}$ haubicos; III AG Raseiniuose: 7-oji baterija - 4 76,2 mm, 8-oji - 2 76,2 mm patrankos, 9-oji - 3127 mm haubicos. Žr.: 2-ojo AP $1936 \mathrm{~m}$. sausio 20 d. raportas. LCVA, f. 1373, ap. 1, b. 246, 1. 4. 
mis $77 \mathrm{~mm} 1916 \mathrm{~m}$. patrankomis ir $105 \mathrm{~mm}$ haubicomis ${ }^{145}$, 4-asis AP $1275 \mathrm{~mm}, 1283,8 \mathrm{~mm}$ patrankų ir $4127 \mathrm{~mm}$ haubicomis ${ }^{146}$.

1936 m., siekiant suvienodinti ginkluotę, 30 senų vokiškų artilerijos pabūklų vis dèlto buvo parduota ${ }^{147}$, tačiau tų pačių metų birželio $12 \mathrm{~d}$. kariuomenès štabas planavo ị Klaipèdą siųsti motorizuotą $277 \mathrm{~mm} 1896 \mathrm{~m}$. pabūklus turintị būrị $i^{148}$. Taigi akivaizdu, kad tuo metu sprendimas parduoti vokiškus pabūklus dar nebuvo priimtas. Tai ịvyko antroje metų puseje, kai $1936 \mathrm{~m}$. liepos $18 \mathrm{~d}$. prasidejo Ispanijos pilietinis karas ir atsirado galimybè skubiai ir pelningai juos realizuoti. 1936 m. lapkričio $1 \mathrm{~d}$. SSRS atstovas Lietuvoje Michailas Karskis ị Maskvą pranešè, kad „Lietuva pardavė Madrido vyriausybei ginklų per privačius asmenis. Išvežė norvegu laivas: artilerijos sviediniai ir angliški šautuvai. Ginklai seni ir prastos kokybès, tačiau kaina aukšta" ${ }^{149}$. Tai patvirtina ir ispaniški šaltiniai, kuriuose teigiama, kad norvegų laivas Linhaug, ị kurị buvo pakrautos $2277 \mathrm{~mm}$ 1916 m. Krupp patrankos ir 8105 mm 1898/09 m. Krupp haubicos, su SSRS konvojumi Y-8 išvyko $1936 \mathrm{~m}$. spalio $26 \mathrm{~d}$., o ị Ispaniją atvyko tụ pačių metų lapkričio $10 \mathrm{~d} .{ }^{150}$ Taigi galima teigti, kad ginklų pardavimo sandoris įvyko $1936 \mathrm{~m}$. rugpjūtį-spalị. Šią prielaidą patvirtina tai, kad 1936 m. rugsejjo $21 \mathrm{~d}$. angliški šautuvai ir amunicija buvo parduoti firmai A. Klaguine už 3164740,2 Lt, o Ginklavimo valdyba už šias lèšas norejo ịsigyti 25000 Mauser šautuvų ir $20 \mathrm{~mm}$ amunicijos ${ }^{151}$. A. Klaguine

145 3-iojo AP 1936 m. sausio 22 d. raportas. LCVA, f. 1373, ap. 1, b. 246, 1. 6.

146 Tauragès igulos I AG ginkluotè - $875 \mathrm{~mm}$ patrankos; Plungès igulos II AG - $283,8 \mathrm{Mk}$ IV ir 4 83,8 mm Mk II patrankos; Klaipèdos igulos II AG būrys - 283,8 mm Mk IV patrankos; Šiaulių igulos III AG - 4 83,8 mm Mk IV ir $475 \mathrm{~mm}$ patrankos, $4127 \mathrm{~mm}$ haubicos. Žr.: 4-ojo AP 1936 m. sausio 22 d. raportas. LCVA, f. 1373, ap. 1, b. 246, 1. 7. Klaipedoje buvusị artilerijos būrị sudarè 2 karininkai, 5 puskarininkiai, 43 kariai ir 35 arkliai. Žr.: Artilerijos inspekcijos 1936 m. balandžio mèn. raportas. LCVA, f. 1373, ap. 1, b. 246, 1. 17.

${ }^{147}$ Ginklavimo valdybos 1936 m. atlikto darbo apyskaita, 1937 m. sausio 9 d. LCVA, f. 1, ap. 1, b. $447,1.2$.

${ }^{148}$ Issakymas III PD vadui 1936 m. birželio 12 d. LCVA, f. 929, ap. 3, b. 887, 1. 38.

${ }^{149}$ Kasparavičius A. Lietuvos kariuomenè Maskvos politinèse ir diplomatinèse spekuliacijose (1920-1936) // Lietuvos nepriklausomybei - 80. Straipsniu rinkinys. Vilnius, 1999, p. 41 .

${ }^{150}$ Artilería para la República pro Artemio Mortyra Pérez, Revista de Historia Militar $\mathrm{n}^{\circ} 18$ Diciembre de 2001 [žiūrèta 201104 28]. Interneto prieiga: <http://www.sbhac.net/ Republica/Fuerzas/Armas/Artilleria/Artilleria.htm>

${ }^{151}$ Ginklavimo valdybos 1936 m. spalio 15 d. raportas. LCVA, f. 3, ap. 1, b. 360, 1. 44. 
firmai pagal $1936 \mathrm{~m}$. spalio $13 \mathrm{~d}$. sutartị Lietuva už 8,010 mln. Lt dar pardavė pabūklų, o vyriausybė sutiko iš šios sumos $2,38 \mathrm{mln}$. Lt skirti numatytiems pabūklams iš tos pačios firmos pirkti. $1936 \mathrm{~m}$. spalio $13 \mathrm{~d}$. Kariuomenès ginklavimo viršininkas I ir II PD vadams ịsaké pasirūpinti, kad artilerijos pulkai ị Centrinį artilerijos sandèlị skubiai grąžintų „visas vokiečių kalibro patrankas ir haubicas, kurias einant sutartimi su firma A. Klaguine yra parduodamos išvežimui iš Lietuvos" ${ }^{{ }_{152}}$. Buvo leista visas lèšas, gautas už parduotus šautuvus ir amuniciją, panaudoti numatytiems ginklams isigyti ${ }^{153}$. Beje, remiantis kitu dokumentu, A. Klaguine firma pagal dvi minètas sutartis Lietuvai $1936 \mathrm{~m}$. iš viso sumokejo 11648 824,80 Lt (iš jų 86 175,52 Lt už transportavimą, dėžes, darbininkams už darbą ir kitas su pirkimu ir gabenimu susijusias paslaugas) ${ }^{154}$.

Kita vertus, lieka neaiškus 5 vokiškų $77 \mathrm{~mm} 1896 \mathrm{~m}$. patrankų, $1105 \mathrm{~mm} \mathrm{1898/09} \mathrm{m}$. haubicos ir 12 angliškų $127 \mathrm{~mm}$ haubicų likimas. Tai, kad 1937 m. gruodžio 15 d. šių pabūklų kariuomenè jau nebeturèjo ${ }^{155}$ ir kad, tikètina, tais pačiai metais sudarytame likviduotino turto sąraše nurodoma sunaikinti 12 angliškų $127 \mathrm{~mm}, 1$ vokiškos $105 \mathrm{~mm}$ haubicos ir $577 \mathrm{~mm} 1896 \mathrm{~m}$. patrankų spynas ${ }^{156}$, leidžia spèti, jog šie 18 pabūklų dèl susidèvejjimo buvo ne parduoti, o tiesiog nurašyti ir utilizuoti. Keletas šiu pabūklų buvo perduoti Karo muziejui, o to meto nuotraukose matyti prie ịejjimo i̇ muziejų stovintys vokiški pabūklai. Painiava gali kilti dèl to, kad pagal $1937 \mathrm{~m}$. vasario 18 d. sutartị Lietuva A.B. Transbaltic (Helsinkyje) pardavè ginklų už 6639 661,45 Lt ir dar 24 673,55 Lt sumokèjo už darbą ir transportavimąa ${ }^{157}$. Taigi lieka neaišku, kokius ginklus Lietuva

\footnotetext{
${ }^{152}$ Kariuomenès ginklavimo viršininko 1936 m. spalio 13 d. įsakymas. LCVA, f. 929, ap. 9, b. 170, 1. 39 .

${ }^{153}$ Lietuvos Respublikos Vyriausybè. 1936 m. spalio 17 d. nuorašas. LCVA, f. 3, ap. 1, b. $360,1.45$.

${ }^{154}$ Firmai A. Klaguine ginklų pardavimo apskaita, 1938 m. gegužis. LCVA, f. 3, ap. 1, b. $417,1.24-25$.

155 Kariuomenès štabo žinios apie esamą ir numatomą apginklavimą $1937 \mathrm{~m}$. gruodžio 15 d. LCVA, f. 1, ap. 1, b. 385, 1. 37-38.

156 Centrinio ginklų sandèlio likviduotino turto sąrašas [be datos]. LCVA, f. 3, ap. 1, b. $472,1.11-16$.

${ }^{157}$ Firmai A. B. „Transbaltic“ ginklų pardavimo apyskaita, 1938 m. gegužis. LCVA, f. 3, ap. 1, b. $417,1.26-27$.
} 
galèjo parduoti. Nors ir nežinant tikslaus parduotų A. Klaguine firmai ginklų skaičiaus, galima iškelti keletą hipotezių: kad vokiški Pirmojo pasaulinio karo minosvaidžiai, dalis angliškų 7,71 mm Ross-Enfield šautuvų, nereikalinga amunicija, galbūt dalis ar visi mūsų minèti 18 pabūklų, kuriuos galimai ne visus ar nevisiškai utilizavo, tikètina, buvo ne viena prekè, o ịvairių ginklų ir amunicijos „rinkinys“.

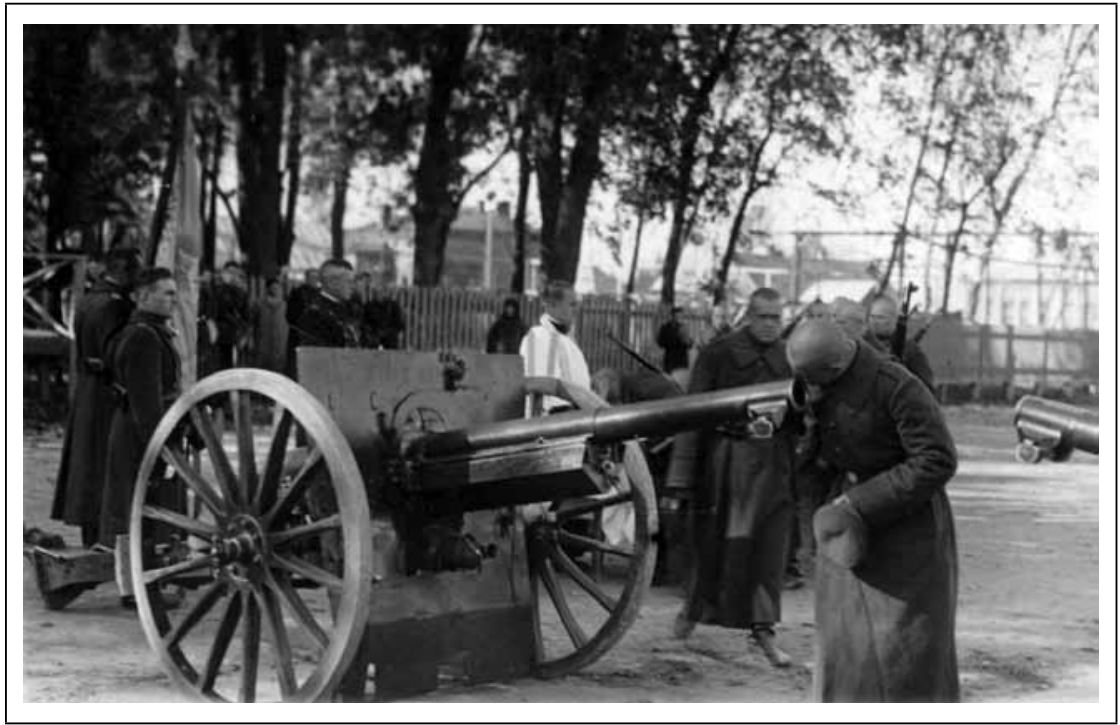

Lietuvos kariuomenės artileristų priesaika. Karys bučiuoja $75 \mathrm{~mm} 1897 \mathrm{~m}$. modelio Schneider (Prancūzija) vamzdị. Iš kairès 3-ias (gilumoje) stovi 1 pèst. pulko vadas plk. Itn. Leonas Gustaitis. Ukmergè, 1936 m. (VDKM)

Igyvendindama apginklavimo planą artilerijos pabūklus Lietuva pirko Prancūzijoje, Suomijoje, Šveicarijoje, Čekoslovakijoje ir Vokietijoje, 1940 m. dar kartą ginklų bandyta įsigyti ir SSRS. 1936 m., antraisiais reformų metais, buvo ịsigytos 36 prancūziškos $75 \mathrm{~mm} 1897 \mathrm{~m}$. modelio patrankos, 11000 sviedinių ir 22000 degtuvų ${ }^{158}$. Pirkinys Lietuvai kainavo

158 Žinios apie 1936 m. ịsigytą turtą, 1937 m. sausio 9 d. LCVA, f. 1, ap. 1, b. 447, 1. 4. 


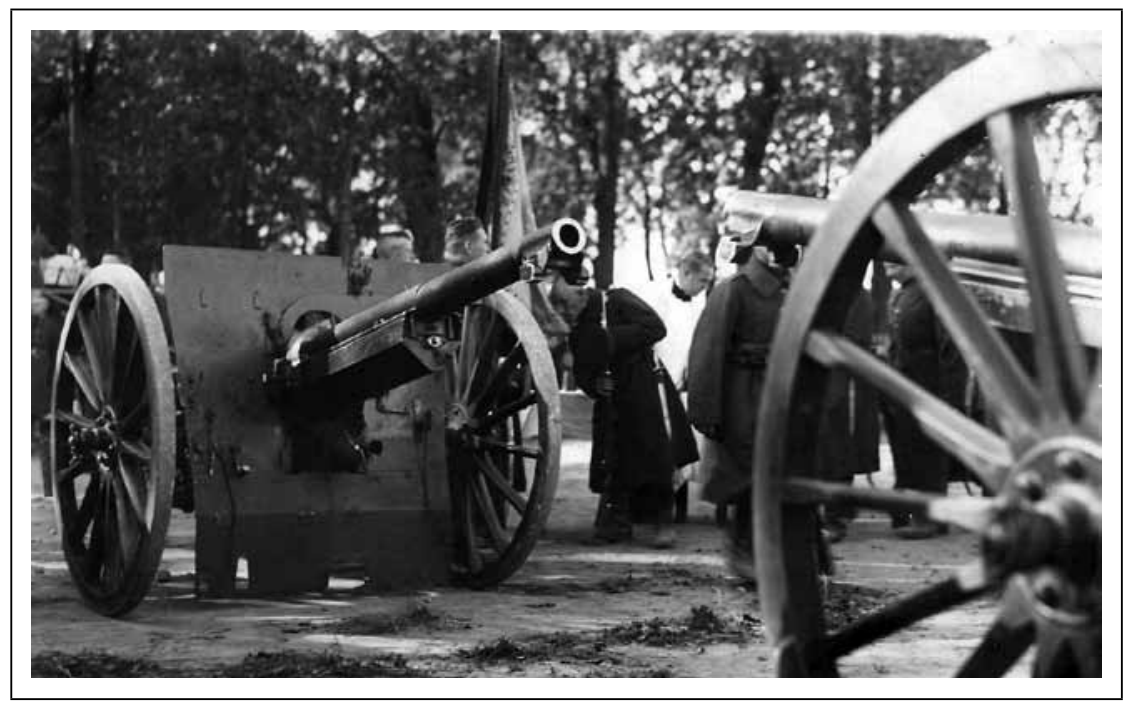

Lietuvos kariuomenès artileristų priesaika. $75 \mathrm{~mm}$

1897 m. Schneider patranka (Prancūzija). XX a. 4 dešimtmetis (VDKM)

7108564 frankus ${ }^{159}$, arba 2,918 mln. Lt. Tais pačiais metais Prancūzijos firmoje Schneider et Cie už 25430100 frankų (apie 9,964 mln. Lt ${ }^{160}$ ) buvo užsakyta $70105 \mathrm{~mm}$ haubicu, 1 pirmagalys ir 21000 sviedinių. 8 pabūklai turèjo būti gauti iki $1937 \mathrm{~m}$. sausio 20 d., 16 - iki vasario 15 d., 24 - iki balandžio 14 d., 22 - iki birželio 14 d. ${ }^{161}$ Tačiau $1937 \mathrm{~m}$. sulaukta tik $48105 \mathrm{~mm}$ pabūklų ${ }^{162}$. Pažymètina, kad Lietuvos kariuomenès ginklų prièmimo komisija konstatavo, jog daug haubicų kaučiukinių bandažų yra atšokę nuo metalinių armatūrų. Šie trūkumai buvo neesminiai, ir komisija pabūklus prièmè, tik prièmimo protokole užfiksavo defektus. Dèl to buvo priimtas sprendimas sulaikyti 21000 Lt už pabūklus mokètinos sumos. Pradejjus šiuos pabūklus naudoti daliniuose ir paaiškèjus, kad nustatyti trūkumai neturi ịtakos jų eksploatacijai ir daugiau ịtrūkių neatsirado, 1938 m. liepos 22 d. plk. ltn. Aloy-

${ }^{159}$ Ginklavimo valdybos 1936 m. užsakytų ir gautų ginklų ir amunicijos sąrašas, $1937 \mathrm{~m}$. sausio 8 d. LCVA, f. 1, ap. 1, b. 447, 1. 7.

${ }^{160} 100$ frankų 1936 m. kainavo 39,18 Lt. Žr.: Statistikos biuletenis. Kaunas, 1936, Nr. 12, p. 20.

${ }^{161}$ Ginklavimo valdybos $1936 \mathrm{~m}$. užsakytų ir gautų ginklų ir amunicijos sąrašas, $1937 \mathrm{~m}$. sausio 8 d. LCVA, f. 1, ap. 1, b. 447, 1. 7.

162 Žinios apie 1937 m. igytą turtą, 1938 m. sausio 18 d. LCVA, f. 1, ap. 1, b. 447, 1. 162. 
zas Banys pasiūlè sulaikytus pinigus išmokèti gamintojui ${ }^{163}$.

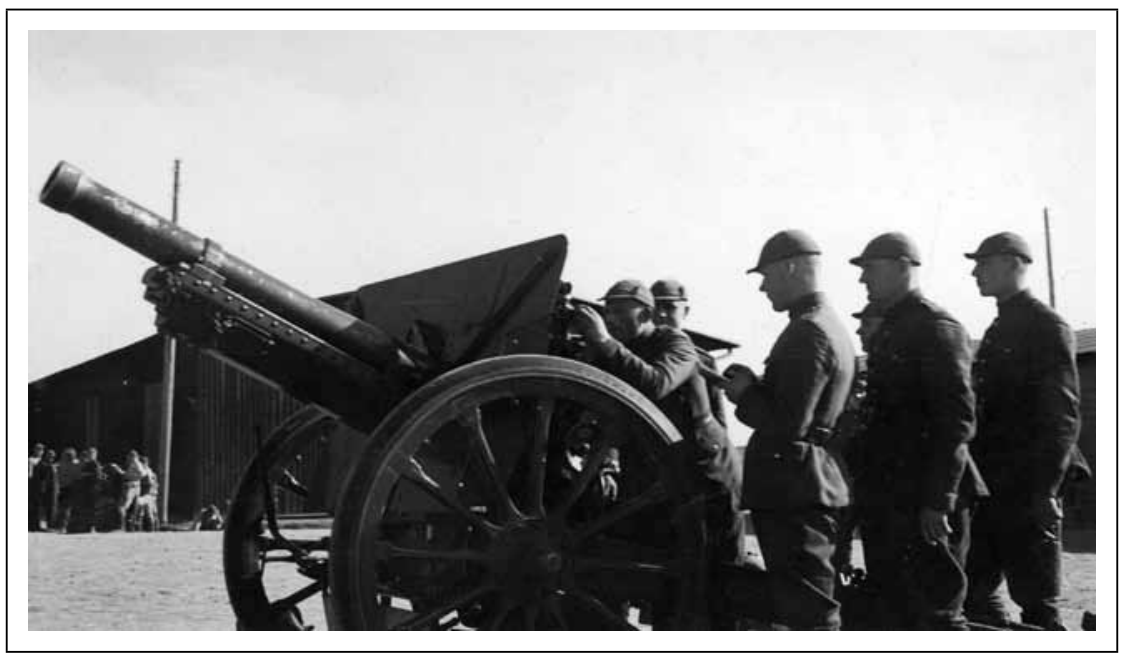

Lietuvos kariuomenès artileristai prie $105 \mathrm{~mm}$ prancūziškos haubicos Schneider-Creusot. 1938-1940 m. (VDKM)

1937 m. birželio 16 d. inž. plk. Stasiui Jurgučiui buvo pavesta vykti ì Prancūziją išsiaiškinti, kada bus galima gauti naują $5075 \mathrm{~mm}$ pabūklų partiją, $75 \mathrm{~mm}$ jūrinių pabūklų, $155 \mathrm{~mm}$ haubicų, 80 prieštankinių $47 \mathrm{~mm}$ pabūklų, $12105 \mathrm{~mm} 17 \mathrm{~km}$. pabūklų (pastaruosius prašyta pagaminti skubiai) ${ }^{164}$.

Kaip minejome, $1936 \mathrm{~m}$. Tammerford Linne-och-Jern Manufacture Aktieblog firmoje Suomijoje buvo nupirkta minosvaidžių ir minų. Pirkinys ${ }^{165}$ kainavo 51500 svarų sterlingų ${ }^{166}$, arba apie 1,52 $\mathrm{mln}$. $\mathrm{Lt}^{167}$.

${ }^{163} 1938 \mathrm{~m}$. liepos 22 d. l. e. Studijų skyriaus viršininko pareigas plk. ltn. A. Banio raportas Nr. 1333/s Ginklavimo viršininkui. LCVA, f. 3, ap. 1, b. 270, 1. 4.

${ }^{164}$ Ginklavimo valdybos viršininko $1937 \mathrm{~m}$. birželio 16 d. įsakymas plk. inž. Jurgučiui. LCVA, f. 3, ap. 1, b. 287, 1. 79.

${ }^{165} 10081,4 \mathrm{~mm}$ Brandt mod. $1934 \mathrm{~m}$. minosvaidžių ir $30000 \mathrm{minų.} \mathrm{Žr.:} \mathrm{Žinios} \mathrm{apie}$ 1936 m. ìsigytą turtą, 1937 m. sausio 9 d. LCVA, f. 1, ap. 1, b. 447, 1. 4.

${ }^{166}$ Ginklavimo valdybos $1936 \mathrm{~m}$. užsakytų ir gautų ginklų ir amunicijos sąrašas, $1937 \mathrm{~m}$. sausio 8 d. LCVA, f. 1, ap. 1, b. 447, 1. 7.

${ }^{167} 1936$ m. 1 D. Britanijos svaras sterlingų kainavo apie 29,5 Lt. Žr.: Statistikos biuletenis. Kaunas, 1936, Nr. 12, p. 20. 


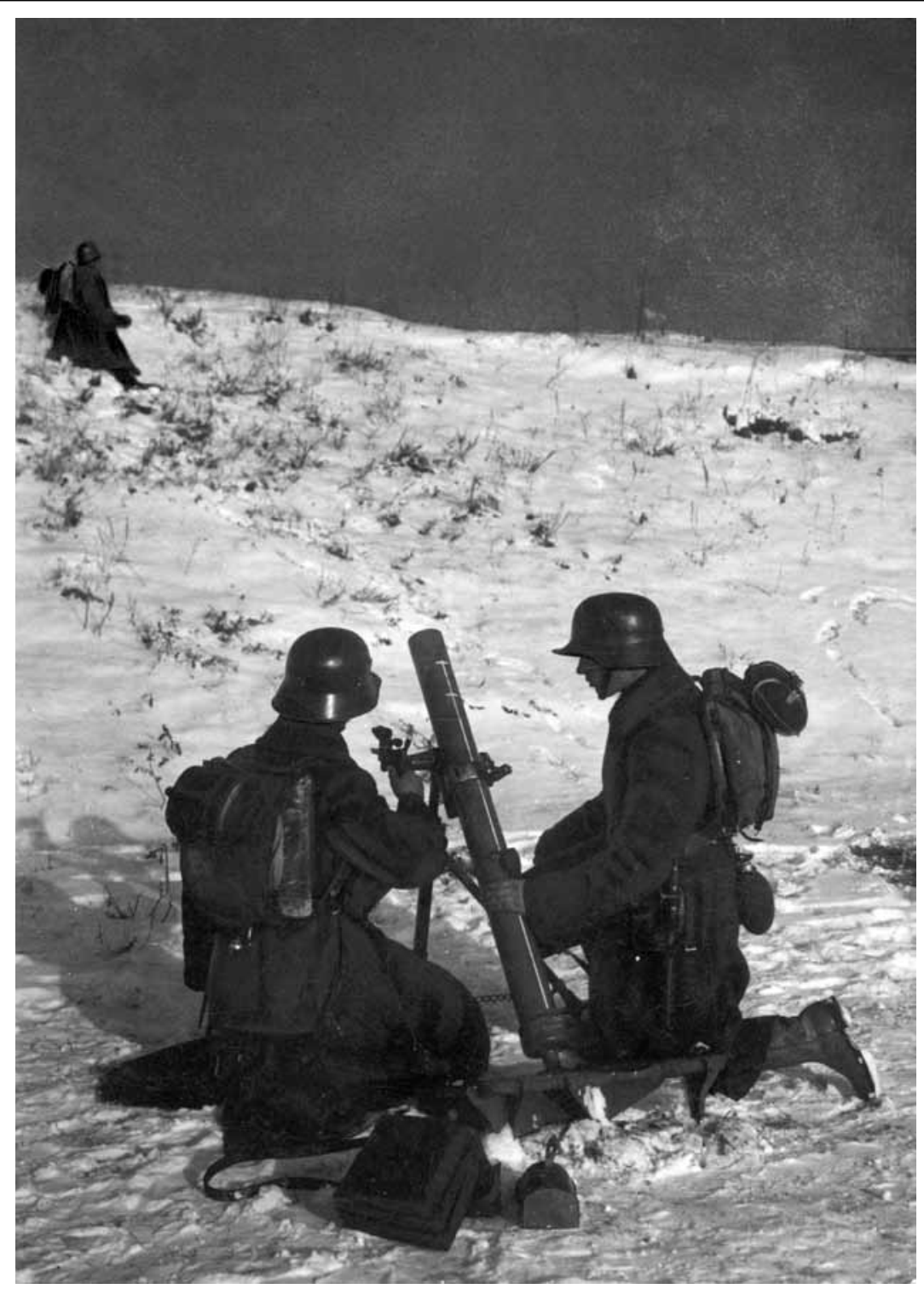

Lietuvos kariai prie $81 \mathrm{~mm}$ Brandt minosvaidžio $1934 \mathrm{~m}$. pozicijoje. 1937 m. Fotografas A. Pajaujis (LCVA) 
Minosvaidžių Stoks-Brand bandymai Lietuvoje vyko 1935 m. Jų metu $2500 \mathrm{~m}$ nuotoliu šaudęs $60 \mathrm{~kg}$ sveriantis ir į tris dalis lengvai išardomas pėstininkų lydimasis pabūklas buvo įvertintas teigiamai ${ }^{168}$. Dar $981,4 \mathrm{~mm}$ 1928 m. pavyzdžio minosvaidžius Lietuvos kariuomenè perèmé iš lenkų 1939 m. rugsèjo mèn., ginklai buvo išbandyti ir perduoti naudoti. 1937 m. su minèta Suomijos firma Lietuvos kariuomenè buvo sudariusi minosvaidžių minų tiekimo sutartị. $1938 \mathrm{~m}$. inž. plk. S. Birutis ir ltn. Bronius Blauzdžiūnas vyko ị Suomijos įmonę Tammerfors Linne-och-Jern Manufacture A.B. priimti ịsigytų $500081 \mathrm{~mm}$ minosvaidžių sviedinių ${ }^{169}$.

Apie 25000 ketinių 81,4 mm minosvaidžių minų kevalų gamybą Lietuvoje yra rašęs istorikas Arvydas Pociūnas ${ }^{170}$. Galima konstatuoti, kad 1938 m. pabaigoje prasidejo derybos su AB Metalas, kuri siūlè, jei būtų užsakyta 50000 vnt., minosvaidžio sviedinio kevalą pagaminti už 19,5 Lt ir buvo pasirengusi įsipareigoti po 4 ménesių nuo sutarties sudarymo dienos kas ménesi pristatyti po 1800 vnt. ${ }^{171}$ Po firmos atstovų asmeninio pokalbio su Lietuvos kariuomenès ginklavimo viršininku firma sutiko nuleisti vieno kevalo kainą iki 17,5 Lt, jei jų bus užsakyta ne mažiau kaip 25 000, ir laikytis anksčiau minètų terminų ${ }^{172}$. Vis dèlto tarptautinis pirkimo konkursas buvo surengtas, tačiau i jo rezultatus nebuvo atsižvelgta. Prancūzijos bendrovès Etablissements Edgar Brandt S.A. pasiūlyta vieno kevalo kaina siekè 4,10 JAV dolerio (24,56 Lt). Suomijos firma Tammerfors Linne-ochJern Manufacture A.B. tokius pat minosvaidžių sviedinių kevalus siūlè pirkti pigiau - po 15,05 Lt už vienetą, o minèta Lietuvos bendrovè - po 17,5 Lt. Tačiau komisija pasirinko AB Metalas, kad karo atveju Lietuvoje būtų įmonè, gaminanti šią produkciją. Be to, vietos gamintojas užsakymą galèjo ịvykdyti per trumpesnị laiką - 4 ménesius. Ir dar vienas privalumas - taip būtų paremta sava pramonè ir lèšos liktų Lietuvoje. Iš viso buvo planuojama pirkti 40000 iš atsparaus ketaus pagamintų kevalų ${ }^{173} .1939$ m. gegužès $23 \mathrm{~d}$. Lietuvos vyriausybé pritare 25000 vnt. $81 \mathrm{~mm}$ Brandt trumpujų minų sviedinių

\footnotetext{
${ }^{168}$ V. Vitkausko 1935 m. birželio 15 d. raportas. LCVA, f. 929, ap. 3, b. 854, 1. 54.

${ }^{169}$ Ginklavimo valdybos 1938 m. spalio 15 d. raportas. LCVA, f. 3, ap. 1, b. 396, 1. 174.

${ }^{170}$ Pociūnas A. Lietuvos kariuomenès ginkluotè ir karinè pramonè 1939-1940 m. // Mokslas ir technika, 1993, Nr. 4, p. 31.

${ }^{171} \mathrm{AB}$,Metalas“ ginklavimo viršininkui, 1938 m. lapkričio 21 d. LCVA, f. 3, ap. 2, b. 237, 1. 78.

${ }^{172} \mathrm{AB}$ „Metalas“ ginklavimo viršininkui, 1939 m. sausio 11 d. LCVA, f. 3, ap. 2, b. 237, 1. 80.

${ }^{173}$ Rungtynių protokolas, 1939 m. sausio 28 d. LCVA, f. 3, ap. 2, b. 237, 1. 10. Kariuomenès tiekimo pirkimų dalies 1939 m. balandžio 14 d. raportas. LCVA, f. 3, ap. 2, b. 237, 1. 3 .
} 
kevalų už 437500 Lt AB Metalas pirkimuii ${ }^{174}$. Buvo apskaičiuota, kad vieno $81 \mathrm{~mm}$ kevalo su „uodegèle“ gamyba kainuoja 10,1 Lt, o įskaitant $25 \%$ pelną, pasiruošimo gamybai ir išlaidas dèl galimo broko - $16,4 \mathrm{Lt}^{175}$.

$1940 \mathrm{~m}$. vasario $18 \mathrm{~d}$. Kaune AB Metalas išliejo pirmąją $81 \mathrm{~mm}$ minų kevalų partiją - 1800 vnt. O dẻl teiginio, kad tai padejo taupyti KAM lèšas ${ }^{176}$, galima ir suabejoti žinant, jog Suomijos firma siūlèsi pigiau atlikti užsakymą. Tačiau neabejotinai svarbu paminèti, kad argumentai, lėmę vietinès firmos pasiūlymo, nors ir šiek tiek brangesnio, pasirinkimą buvo svarūs ir nenuginčijami.

1937 m. kariuomenè iš specialiųjų lèšu ịsigijo $1420 \mathrm{~mm}$ Hispano-Suiza S-7 lèktuvų pabūklų ${ }^{177}$ ir 8400 jų sviedinių už $0,524 \mathrm{mln}$. $\mathrm{Lt}^{178}$. Šiais pagal Oerlikon licenciją pagamintais pabūklais buvo apginkluoti 1937 m. įsigyti 14 Dewoitine D.501L naikintuvų ${ }^{179}$. Pabūklai, kainavę 1868322 Prancūzijos frankus, ị Lietuvą turèjo būti pristatyti iki $1937 \mathrm{~m}$. gegužès $17 \mathrm{~d} .{ }^{180}$

$1937 \mathrm{~m}$. spali kariuomene įsigijo $3675 \mathrm{~mm}$ patrankas, 21600 granatų ir 39487 jų degtuvus ${ }^{181}$. Šie ginklai buvo ịsigyti ne pagal apginklavimo planą, o iš specialiụjų lèšų. Pabūklai ir 36000 sviedinių kainavo 3,6 mln. Lt. Be to, buvo nupirkta 5000 minosvaidžių minų už $0,573 \mathrm{mln}$. Lt, $6000020 \mathrm{~mm}$ sviedinių už $0,95 \mathrm{mln}$. Lt ir 100000 šių sviedinių degtuvų už $0,3 \mathrm{mln}$. $\mathrm{Lt}^{182}$.

1937 m. karo atveju Lietuva planavo mobilizuoti 4 PD, 2 PB ir kt. dalinius. Taip pat norèta turèti $8 \mathrm{AP}$ ir raitąją AG, iš viso 258 patrankas ir haubicas, tačiau disponavo tik 211 pabūklų (5 lentelè). Dèl to realiai galejo mobilizuoti 53, o ne 64 baterijas, kaip buvo numatyta, ir užtikrinti, kad visi planuoti karo meto $16 \mathrm{PP}$ mūšyje būtų remiami $1 \mathrm{GA}$, o $3 \mathrm{KP}$ turètų po raitosios artilerijos bateriją. Taigi didelio atotrūkio tarp turètos

\footnotetext{
${ }^{174}$ LR Ministrų Taryba, 1939 m. gegužès 24 d. LCVA, f. 3, ap. 2, b. 237, 1. 1.

${ }^{175} 81 \mathrm{~mm}$ sviedinių kevalams lieti liejyklos duomenys. LCVA, f. 3, ap. 2, b. 237, 1. 26-30.

${ }^{176}$ Pociūnas A. Lietuvos kariuomenès minosvaidžiai 1921-1940 metais // Kardas, 2003, Nr. 2, p. 37.

177 Žinios apie 1937 m. igytą turtą, 1938 m. sausio 18 d. LCVA, f. 1, ap. 1, b. 447, 1. 162.

${ }^{178}$ İsigyta už specialias lèšas. LCVA, f. 929, ap. 9, b. 163, 1. 23.

${ }^{179}$ Rezmer W. Litewskie lotnictwo wojskowe 1919-1940. Toruń, 1999, s. 206-208.

${ }^{180}$ Ginklavimo valdybos $1936 \mathrm{~m}$. užsakytų ir gautų ginklų bei amunicijos sąrašas $1937 \mathrm{~m}$. sausio 8 d. LCVA, f. 1, ap. 1, b. 447, 1. 7.

${ }^{181}$ Žinios apie ginklavimo turtą 1937 m. spalio mèn. LCVA, f. 1, ap. 1, b. 447, 1. 108.

${ }^{182}$ İsigyta už specialias lèšas. LCVA, f. 929, ap. 9, b. 163, 1. 23.
} 
artilerijos ir mobilizacijos planų iš esmès nebuvo.

5 lentele Lietuvos kariuomenès artilerijos pabūklų paskirstymo 1937 m. pulkuose planas ${ }^{183}$

\begin{tabular}{|c|c|c|c|c|c|c|c|c|c|c|c|c|c|}
\hline $\begin{array}{l}\text { Pabūklo } \\
\text { modelis }\end{array}$ & 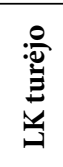 & $\sum$ & $\sum_{2}^{2}$ & $\sum_{n}^{2}$ & $\sum_{4}^{2}$ & $\sum_{i}^{0}$ & $\sum_{0}^{2}$ & $\begin{array}{l}\dot{z} \\
\dot{\infty} \\
\dot{\alpha}\end{array}$ & 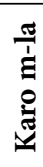 & كُ & 灾 & 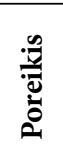 & 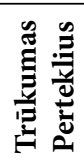 \\
\hline $\begin{array}{l}75 \mathrm{~mm} \\
\text { patrankos }\end{array}$ & 108 & 24 & 24 & 24 & 26 & 16 & 16 & 14 & 4 & & & 148 & -40 \\
\hline $\begin{array}{l}76,2 \mathrm{~mm} \\
\text { patrankos }\end{array}$ & 19 & & & & & & & & & 12 & & 12 & +7 \\
\hline $\begin{array}{l}84 \mathrm{~mm} \\
\text { patrankos }\end{array}$ & 12 & & & & & & & & & & & 0 & +12 \\
\hline $\begin{array}{l}105 \mathrm{~mm} \\
\text { haubicos }\end{array}$ & $70^{\star}$ & 12 & 12 & 12 & 12 & 8 & 8 & 4 & 2 & & & 70 & 0 \\
\hline $\begin{array}{l}105 \mathrm{~mm} \\
\text { patrankos }\end{array}$ & 0 & & & & & & & 2 & & & 12 & 14 & -14 \\
\hline $\begin{array}{l}155 \mathrm{~mm} \\
\text { haubicos }\end{array}$ & 2 & & & & & & & 2 & & & 12 & 14 & -12 \\
\hline Iš viso & 211 & 36 & 36 & 36 & 38 & 24 & 24 & 22 & 6 & 12 & 24 & 258 & $\begin{array}{c}-66 / \\
+19 \\
\end{array}$ \\
\hline
\end{tabular}

* $1937 \mathrm{~m}$. Lietuvos kariuomenè turejo tik $48105 \mathrm{~mm}$ haubicas, likusias nupirktas 22 gavo $1938 \mathrm{~m}$.

Tačiau tais pačiais $1937 \mathrm{~m}$. artilerijos inspektorius numatè, kad ateityje karo atveju mobilizavus kariuomenę bus ne 4 , o $5 \mathrm{PD}$, todèl reikètų turèti $10875 \mathrm{~mm}, 1976,2 \mathrm{~mm}, 1283,8 \mathrm{~mm}, 36105 \mathrm{~mm}$ ir $4155 \mathrm{~mm}$ patrankas, $110105 \mathrm{~mm}$ ir $24155 \mathrm{~mm}$ haubicas ir visa tai paskirstyti 9 AP, raitosios artilerijos ir pakrančių apsaugos grupėms. Ateityje siūlyta AP divizijoms skirti ne po 24 patrankas ir 12 haubicų, o po 16 patrankų ir 20 haubicų, nes pastarųjų: 1) sviedinių galia buvo trigubai didesnè; 2) sviediniai dèl aukštos lèkimo trajektorijos pasiekia taikinius už ir aukštesnių priedangų; 3) dèl iškiliosios šūvio trajektorijos haubicų pozicijas lengva

${ }^{183}$ Kariuomenès ginklavimo viršininko 1937 m. gruodžio 15 d. raportas. LCVA, f. 929, ap. 9, b. 163, ap. 1. 9 . 
i̇rengti už priedangų, miškingoje vietovèje. Pažymèta, kad Vokietija padidino savo PD $105 \mathrm{~mm}$ haubicų skaičių, o lietuvių naudotos $75 \mathrm{~mm}$ patrankos, nors ir puikus ginklas, šaudant didesniu kaip $5 \mathrm{~km}$ atstumu turèjo būti gerai ịtvirtintos, todèl jų noragams reikèjo kasti gilius griovius, o žiemą, esant ịšalui, tai padaryti buvo sunku. Be to, šių patrankų ugniavietėms miškuose buvo nelengva rasti tinkamą vietą. Taip pat paaiškejjo, kad Prancūzija prekiavo gerokai padèvètomis $75 \mathrm{~mm} 1897 \mathrm{~m}$. patrankomis. Todèl pasiūlyta, užuot bandžius ịsigyti trūkstamų 40 šio kalibro patrankų, ateityje nupirkti 40 naujų $105 \mathrm{~mm}$ haubicų (6 lentelè) ${ }^{184} .1938 \mathrm{~m}$. pakoreguotame kariuomenès apginklavimo plane, ị šiuos pasiūlymus atsižvelgus, kaip minejjome, nurodyta įsigyti tik $3675 \mathrm{~mm}$ patrankas (visos jau buvo nupirktos) ir $120105 \mathrm{~mm}$ haubicų (70 buvo nupirkta).

6 lentele 1937 m. artilerijos pabūklų poreikio ir siūlomų issigyti priemonių duomenų suvestiné $\dot{1}^{185}$

\begin{tabular}{|c|c|c|c|c|c|c|c|}
\hline \multirow[b]{2}{*}{ Daliniai } & \multicolumn{5}{|c|}{ Patrankos } & \multicolumn{2}{|c|}{ Haubicos } \\
\hline & $\begin{array}{c}75 \\
\mathrm{~mm}\end{array}$ & $\begin{array}{l}76,2 \\
\mathrm{~mm}\end{array}$ & $\begin{array}{l}83,8 \\
\mathrm{~mm}\end{array}$ & $\begin{array}{l}105 \\
\mathrm{~mm}\end{array}$ & $\begin{array}{l}155 \\
\mathrm{~mm}\end{array}$ & $\begin{array}{l}105 \\
\mathrm{~mm}\end{array}$ & $\begin{array}{l}155 \\
\mathrm{~mm}\end{array}$ \\
\hline 5 divizijų AP * & 80 & - & - & - & - & 100 & - \\
\hline $\mathrm{RAG}^{\star *}$ & 12 & - & - & - & - & - & - \\
\hline $\mathrm{KAP}^{\star * *}$ & 8 & 8 & 8 & - & - & - & - \\
\hline Atsargos AP & 8 & 11 & 4 & - & - & 10 & - \\
\hline $2 \mathrm{SAP}^{\star * \star *}$ & - & - & - & 36 & - & - & 24 \\
\hline Pakrančių AG & - & - & - & - & 4 & - & - \\
\hline Iš viso siūlyta turèti & 108 & 19 & 12 & 36 & 4 & 110 & 24 \\
\hline Buvo & 108 & 19 & 12 & - & - & 70 & 2 \\
\hline Siūlyta ịsigyti & - & - & - & 36 & 4 & 40 & 22 \\
\hline
\end{tabular}

*Siūlyta turèti 5 divizijų AP: kiekviename po $1675 \mathrm{~mm}$ patrankų ir $20105 \mathrm{~mm}$ haubicų.

${ }^{*}$ Raitosios artilerijos grupé -3 baterijos po 4 patrankas.

${ }^{* * *}$ Kariuomenès lengvosios artilerijos pulkas -3 grupès po 2 baterijas.

$* * * * 2$ sunkiosios artilerijos pulkai (SAP) -5 grupès.

Iki $1938 \mathrm{~m}$. gegužès $21 \mathrm{~d}$. pagal planą buvo įsigyta ginklų ir amu-

${ }^{184}$ Artilerijos inspekcijos 1937 m. rugsèjo mèn. siūlymas kariuomenès vadui dèl artilerijos apginklavimo. LCVA, f. 1373, ap. 1, b. 260, 1. 8-11.

185 Ten pat, 1. 8-11. 
nicijos už $61,906 \mathrm{mln}$. Lt, tačiau iš tikrųjų išleista $57,733 \mathrm{mln}$. Lt - dar 4,175 mln. Lt liko nesumokèta prancūzų firmai už $105 \mathrm{~mm}$ haubicas, tai padaryti ketinta 1939-1941 m. Kariuomenè nusipirko $70105 \mathrm{~mm}$ haubicų (36 000 sviedinių) už 12,514 mln. Lt, $3675 \mathrm{~mm}$ patrankas (11 000 sviedinių) už 2,918 mln. Lt ir $10281,4 \mathrm{~mm}$ minosvaidžius (30 $000 \mathrm{minų}$ ) už 1,536 mln. Lt $^{186}$.

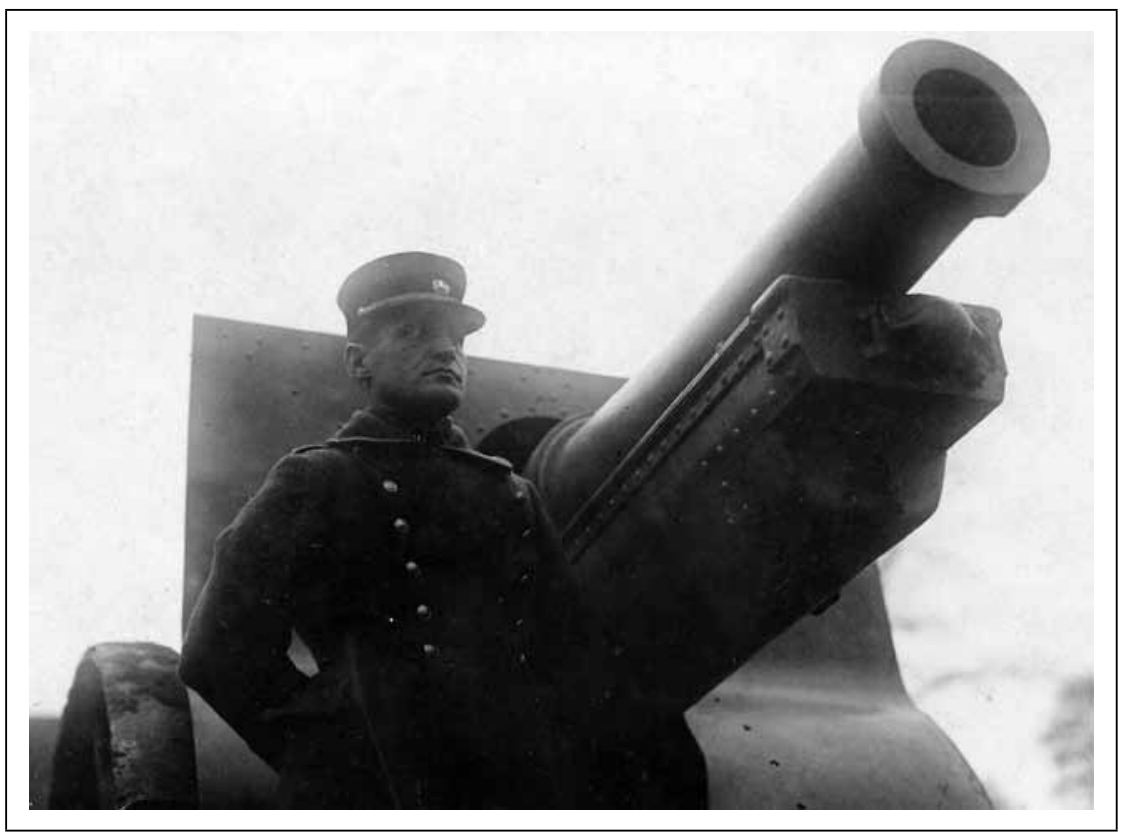

$155 \mathrm{~mm}$ haubica Schneider (Prancūzija) ir prie jos stovintis karininkas (asmeninés Simono Turausko kolekcijos nuotrauka)

1938 m. rugpjūčio 18 d. Lietuva su Škoda firma sudarè $24105 \mathrm{~mm}$ hruby kanon vz.35 patrankų ${ }^{187}$, kurias Lietuva turejjo gauti iki $1940 \mathrm{~m}$. rugpjūčio mèn., pirkimo sutartị ${ }^{188}$. Vèliau konstatuota, kad pirmoji partija (2 baterijos) užsakovą turètų pasiekti $1940 \mathrm{~m}$. balandžio mẻn., taip

${ }^{186}$ Vykdant ginklavimo planą ịsigyta, 1938 m. gegužès 21 d. LCVA, f. 929, ap. 9, b. 163, 1. 20-21.

${ }^{187}$ Etablissements Škodas a Plzeń 1939 m. rugpjūčio 5 d. LCVA, f. 3, ap. 2, b. 232, 1. 11.

${ }^{188}$ Ginklavimo valdyba 1939 m. rugpjūčio 30 d. LCVA, f. 3, ap. 2, b. 232, ap. 1. 6. 
pat jog dèl lèšų stokos šie pabūklai nebus motorizuoti, kaip planuota anksčiau ${ }^{189} .24$ pabūklams (6 baterijoms) motorizuoti būtų prireikę apie $3,8755 \mathrm{mln}$. $\mathrm{Lt}^{190}$. Užsakyti pabūklai kainavo apie 3,3 mln. Lt.

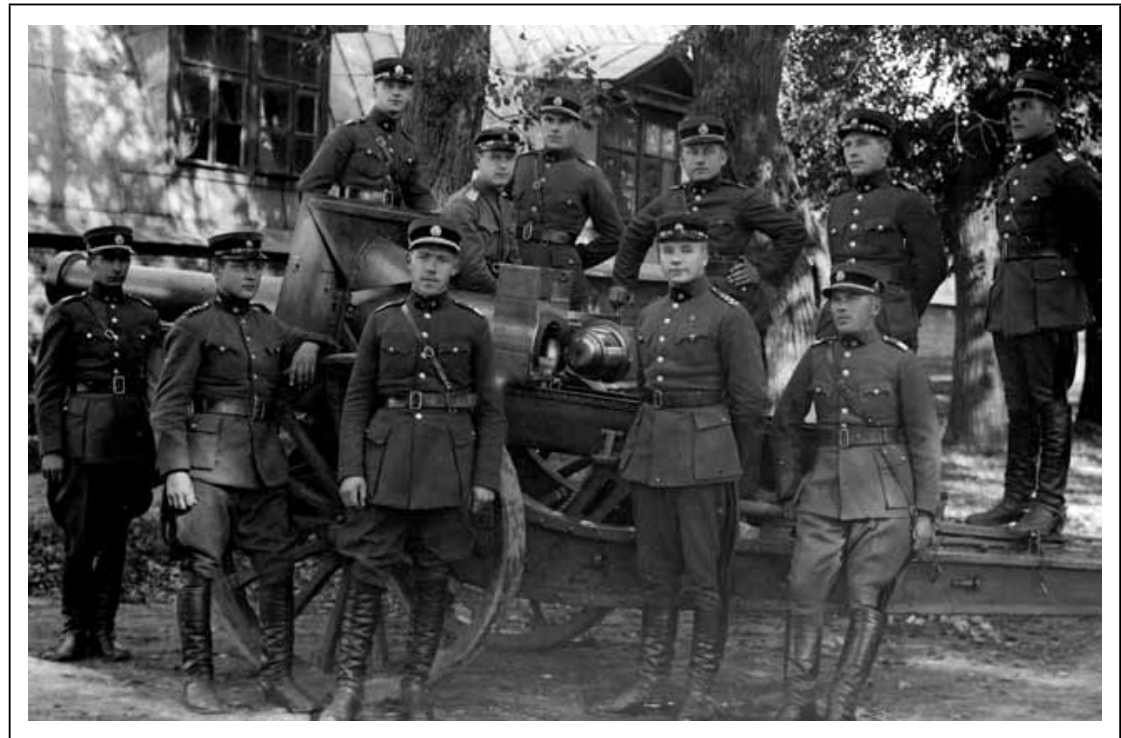

155 mm haubica Schneider (Prancūzija) ir grupè karininkų (asmeninés Simono Turausko kolekcijos nuotrauka)

1940 m. pradžioje Lietuva gavo pirmuosius 4 čekiškus pabūklus, dar 8 patrankos tų pačių metų birželio mèn. vokiečių buvo sulaikytos Eitkūnų geležinkelio stotyje, tad Lietuvos nepasiekè ${ }^{191}$. Šiais pabūklais buvo planuojama apginkluoti 21-ąj sunkiosios artilerijos pulką, kurị būtų sudariusios 3 AG, kiekviena po 2 baterijas ${ }^{192}$. Tačiau $1940 \mathrm{~m}$. birželio pradžioje naujo AP dislokacijos, organizacijos ir transportavimo klausimai dar tik buvo svars-

${ }^{189}$ Ginklavimo valdybos 1939 m. lapkričio 17 d. raportas. LCVA, f. 3, ap. 2, b. 232, 1. 4.

190 Tyrimų komisijos 1939 m. rugsejjo 15 d. posèdžio protokolas. LCVA, f. 3, ap. 2, b. 232, 1. 8 . ${ }^{191}$ Pociūnas A. Lietuvos kariuomenès ginkluotè ir karinè pramonė 1939-1940 m. // Mokslas ir technika, 1993, Nr. 4, p. 30.

${ }^{192}$ Artilerijos inspekcijos 1939 m. rugsèjo 13 d. raportas. LCVA, f. 3, ap. 2, b. 232, 1. 10; Artilerijos inspektoriaus $1940 \mathrm{~m}$. birželio $1 \mathrm{~d}$. raportas kariuomenès vadui. LCVA, f. 1373, ap. 1, b. $311,1.105$. 
tomi. Tačiau motorizuotų artilerijos padalinių kariuomenėje buvo, nes jau anksčiau mėginta traukti pritaikyti $75 \mathrm{~mm} 1897 \mathrm{~m}$. patrankas, bandant ìvairių firmų ištisinius ratus su pneumatinėmis padangomis ${ }^{193} .1938 \mathrm{~m}$. kovo $5 \mathrm{~d}$. buvo suformuotas 4-ojo AP motorizuotasis artilerijos būrys ${ }^{194}$, vèliau toks būrys sukurtas ir prie Karo mokyklos Mokomosios grupès ${ }^{195}$.

1939 m. sausio mèn. Lietuva iš Šveicarijos firmos Werkzeugmaschinenfabrik Oerlikon Buehrle \& Co pagal 1938 m. birželio 1 d. sutartị ${ }^{196}$ gavo $2520 \mathrm{~mm}$ Oerlikon $1 S$ tipo tankų pabūklus ${ }^{197}$. Šis pirkinys Lietuvai atsiejjo 626388,75 Šveicarijos franko ${ }^{198}$, arba sutarties dienos kursu 854 707,50 Lt ${ }^{199}$. Vienas pabūklas kainavo 16680 frankų. Likusi sumos dalis buvo sumokèta už priedus ir atsargines dalis ${ }^{200}$. Krovinys per Antverpeną ị Klaipèdą buvo atplukdytas laivu Utena ${ }^{201}$. Pabūklai buvo pritaikyti montuoti tankuose. Reikia manyti, kad jie buvo skirti naujiems Čekoslovakijoje pagamintiems LTL tankams. Tačiau jie Lietuvos nepasiekè, o kitur pabūklai naudoti netiko, nes neturèjo lafetų. Nepavyko nustatyti, kokiu tikslu 1939 m. buvo ịsigytas dar

1931939 m. balandžio 19 d. Artilerijos inspektoriaus raštas Ginklavimo viršininkui apie iš JAV firmos „Martin-Parry corp.“ gautą vieną guminių ratų 1897 m. patrankoms komplektą ir numatytus važinejjimo ir šaudymo bandymus. Žr.: LCVA, f. 3, ap.1, b. 270, 1. 2; 1938 m. kovo 3 d. raportas Ginklavimo viršininkui Nr. 16 dèl firmos „Englebert et. Co“ ratų, ten pat, 1. 21; Firmos „Englebert et. Co“ pasiūlymas prancūzų kalba, su nuotraukomis, ten pat, 1. 22-26.

1941938 m. kovo 5 d. 4-ojo artilerijos pulko vado gen. št. plk. J. Juodišiaus slaptas raportas III pèstininkų divizijos vadui. LCVA, f. 1373, ap. 1, b. 287, 1. 3.

${ }^{195}$ Karo mokyklos mot. artilerijos būrys nurodytas ir Karo aviacijos štabo 1939-09-18 Pietų ir rytų sienai saugoti direktyvoje Nr. 1325, slaptas-operatyvinis. LCVA, f. 1323, ap. 1, b. $556,1.48$.

196 Werkzeugmaschinenfabrik Oerlikon Buehrle \& Co. 1939 m. kovo 10 d. LCVA, f. 3, ap. 2, b. $186,1.10$.

1971939 m. vasario 28 d. protokolas. LCVA, f. 3, ap. 2, b. 186, 1. 12.

${ }^{198}$ Ginklavimo valdybos 1938 m. birželio 10 d. raštas Finansų ministerijai. LCVA, f. 3, ap. 2, b. 186, 1. 122.

${ }^{199}$ Lietuvos pasiuntinybė Šveicarijoje 1938 m. birželio 10 d. LCVA, f. 3, ap. 2, b. 186, 1. 124. Remiantis kitu dokumentu $2520 \mathrm{~mm}$ Oerlikon $1 S$ automatiniai tankuose montuojami pabūklai Lietuvai kainavo 626 388,75 Šveicarijos franko, arba 864105 Lt. Žr.: KAM raštas ministrui pirmininkui $1938 \mathrm{~m}$. kovo 17 d. LCVA, f. 3, ap. 2, b. 185, 1. 2.

${ }^{200}$ Sutartis Nr. 141, 1938 m. birželio 1 d. LCVA, f. 3, ap. 2, b. 186, 1, 143.

${ }^{201}$ Prancūzijos pasiuntinybei 1939 m. balandžio 26 d. LCVA, f. 3, ap. 2, b. 186, 1. 1. 
vienas $20 \mathrm{~mm}$ SLaS modelio Oerlikon pabūklas ${ }^{202}$.

Aptariamuoju laikotarpiu $20 \mathrm{~mm}$ priešlèktuvinis šovinys Belgijoje kainavo 15,50 Belgijos franko (apie 15,83 Lt), jų 1937 m. Lietuva Fabrique Nationale d'Armes de Guerre S.A. buvo užsakiusi 60000 iš viso už 930000 frankų. Bet pateikta amunicija buvo nekokybiška, todèl firma pasiūlè pirkti prieštankinių šovinių, kurių vienas kainavo 12 frankų $(12,25 \mathrm{Lt})$. Tokios pat rūšies šovinio firmoje Oerlikon kaina siekè 27,62 Lt. Pakeitus sutartị, Lietuva turèjo gauti 72360 prieštankinių ir priešlèktuvinių $20 \mathrm{~mm}$ šovinių ${ }^{203}$. Naudojant pabūklus prieš tankus ir kitą šarvuotąją techniką $300 \mathrm{~m}$ atstumu jie galejo pramušti $40 \mathrm{~mm}, 500 \mathrm{~m}-30 \mathrm{~mm}$, $1000 \mathrm{~m}-20 \mathrm{~mm}$, o $1200 \mathrm{~m}$ - $15 \mathrm{~mm}$ šarvą ${ }^{204}$.

1938 m. Karo taryboje apsvarsčius Oerlikon pabūklų keitimo klausimą buvo nutarta turimus ginklus pakeisti ị modernesnius $20 \mathrm{~mm} B S W$ firmos automatinius pabūklus, o senuosius Oerlikon parduoti, kai bus gauta ne mažiau kaip 100 naujų pabūklų ir užsakyta amunicija. Be to, nuspręsta kuo skubiau issigyti 45 prieštankinius $47 \mathrm{~mm}$ pabūklus ${ }^{205}$. Nors dar $1936 \mathrm{~m}$. Karo taryba konstatavo, kad „kol santykiai su vokiečiais nesunormuoti, pirkimas vokiškose firmose turi būti vykdomas su dideliu atsargumu" ${ }^{\text {"206, }}$, vis dèlto $1939 \mathrm{~m}$. buvo ịsigyta $1502 \mathrm{~cm}$ Flak 30 pabūklų, nes vykdant ginklavimosi planą buvo nutarta iš Vokietijos firmos Barlin-Suhler Waffen-und Fahrzeugwerke pirkti

${ }^{202}$ Ginklavimo viršininkui apginklavimo žinios 1939.IX.1 LCVA, f. 3, ap. 1, b. 256, 1. 7.

${ }^{203}$ Ministrui Pirmininkui, 1939 m. gegužès 20 d. Nr. 3924. LCVA, f. 384, ap. 2, b. 1069, 1. $131-131$ a. 1.

${ }^{204}$ Statkus V. Lietuvos ginkluotos pajegos 1918-1940 m. Chicago, 1986, p. 534. Pabūklas žygio metu su pirmagaliu svèrè $850 \mathrm{~kg}$, pozicijose su ratais $-310 \mathrm{~kg}$, ant trikojo - $278 \mathrm{~kg}$, greitašauda - apie 200 šūvių per min. It oro taikinius buvo galima šaudyti iki $2000 \mathrm{~m}$ aukščio, ị tankus - iki $500 \mathrm{~m}$, o ị gyvus taikinius horizontali veiksminga ugnis siekè iki $3700 \mathrm{~m}$. Iš $500 \mathrm{~m}$ atstumo pabūklas galejjo pramušti $20 \mathrm{~mm}$ šarvą. Šaudyti pabūklą buvo galima parengti per 45 sekundes. Žr.: Péstininku statutas. Kautynès. II dalis. Kaunas, 1939, p. 33.

${ }^{205}$ Karo tarybos posedyje dalyvavę nariai: tarybos pirmininkas, krašto apsaugos ministras brg. gen. Stasys Dirmantas, kariuomenès vadas brg. gen. Stasys Raštikis, štabo viršininkas brg. gen. Jonas Černius, tiekimo viršininkas brg. gen. Zenonas Gerulaitis ir II PD vadas div. gen. Edvardas Adamkavičius; kviestiniai asmenys: pėstininkų inspektorius brg. gen. V. Vitkauskas, priešlèktuvinès rinktinès viršininkas plk. Povilas Babickas, ginklavimo viršininko pavaduotojas plk. Juozas Vèbra. Žr.: Karo tarybos 1938 m. vasario 26 d. posèdžio protokolo Nr. 35 nuorašas. LCVA, f. 3, ap. 1, b. 275, 1. 3.

${ }^{206}$ Karo tarybos 1936 m. gruodžio 30 d. posėdžio protokolo nuorašas. LCVA, f. 3, ap. 1, b. $275,1.3$. 
150 priešlèktuvinių automatinių $20 \mathrm{~mm}$ pabūklų, 81000 jų šovinių ir sprogstamųų šovinių gamybos licenciją. Šis pirkinys kainavo apie 8,5323 mln. $\mathrm{Lt}^{207}$.

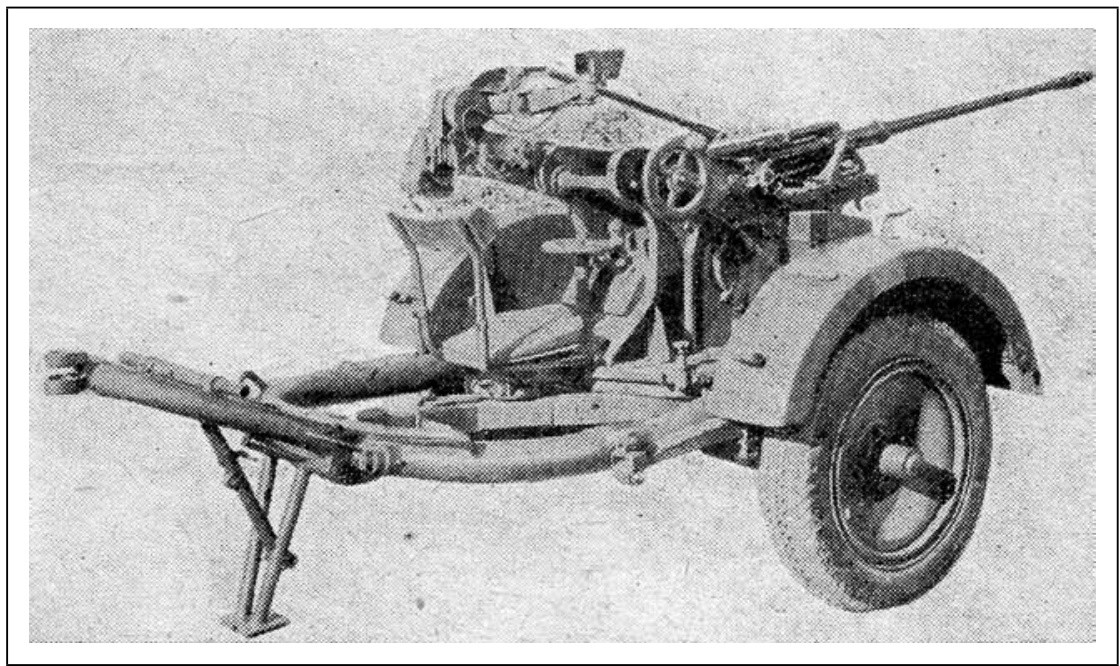

BSW, arba LAP (lekktuvinis automatinis pabūklas), $2 \mathrm{~cm}$ Flak 30 automatinis pabūklas parengtas šaudyti nuo važiuoklès. Technika. P. 85. Kaunas, 1940

Tai buvo labai panašūs ị Oerlikon pabūklai ${ }^{208}$. Pirmieji 120 pabūklų ir amunicija Lietuvą turejo pasiekti 1939 m., likusieji 30 - iki 1940 m. vasario $28 \mathrm{~d} .{ }^{209}$ Lietuvos kariuomenès dokumentuose šie pabūklai vadinami BSW arba LAP (lèktuviniais automatiniais pabūklais). $2 \mathrm{~cm}$ Flak 30 ir šio pabūklo modifikacijos buvo itin sèkmingai naudojamos Antrajame pasauliniame kare pritaikius motorizuotai traukai ir sumontavus modernų automatini firmos Zeiss taikiklį. Lietuvos kariuomenèje LAP pabūklais buvo ginkluotos motorizuotosios priešlèktuvinès kuopos, vèliau turèjo būti apginkluoti ir kiti daliniai, planuota juos naudoti ir prieštankinei gynybai ${ }^{210}$.

Priešlèktuvinès motorizuotosios kuopos 1939 m. rugsèjo $15 \mathrm{~d}$. buvo pradètos formuoti: 1-oji kuopa (skirta I PD) - Panevėžyje, 2-oji (II PD) - Kaune

\footnotetext{
${ }^{207}$ Ministrui pirmininkui 1939 m. sausio 7 d. LCVA, f. 384, b. 1069, 1. 2.

${ }^{208}$ Statkus V. Lietuvos ginkluotos pajegos 1918-1940 m., Chicago, 1986, p. 539.

${ }^{209}$ Ministrui pirmininkui 1939 m. sausio 19 d. LCVA, f. 384, b. 1069, 1. 15.

${ }^{210}$ LAP dalinių mokymo darbotvarkè, Kaunas, 1940, Kariuomenès štabas, Spaudos ir švietimo skyrius, p. 10.
} 


\section{LIETUVOS RESPUBLIKOS KARIUOMENĖ 1918-1940 M.}

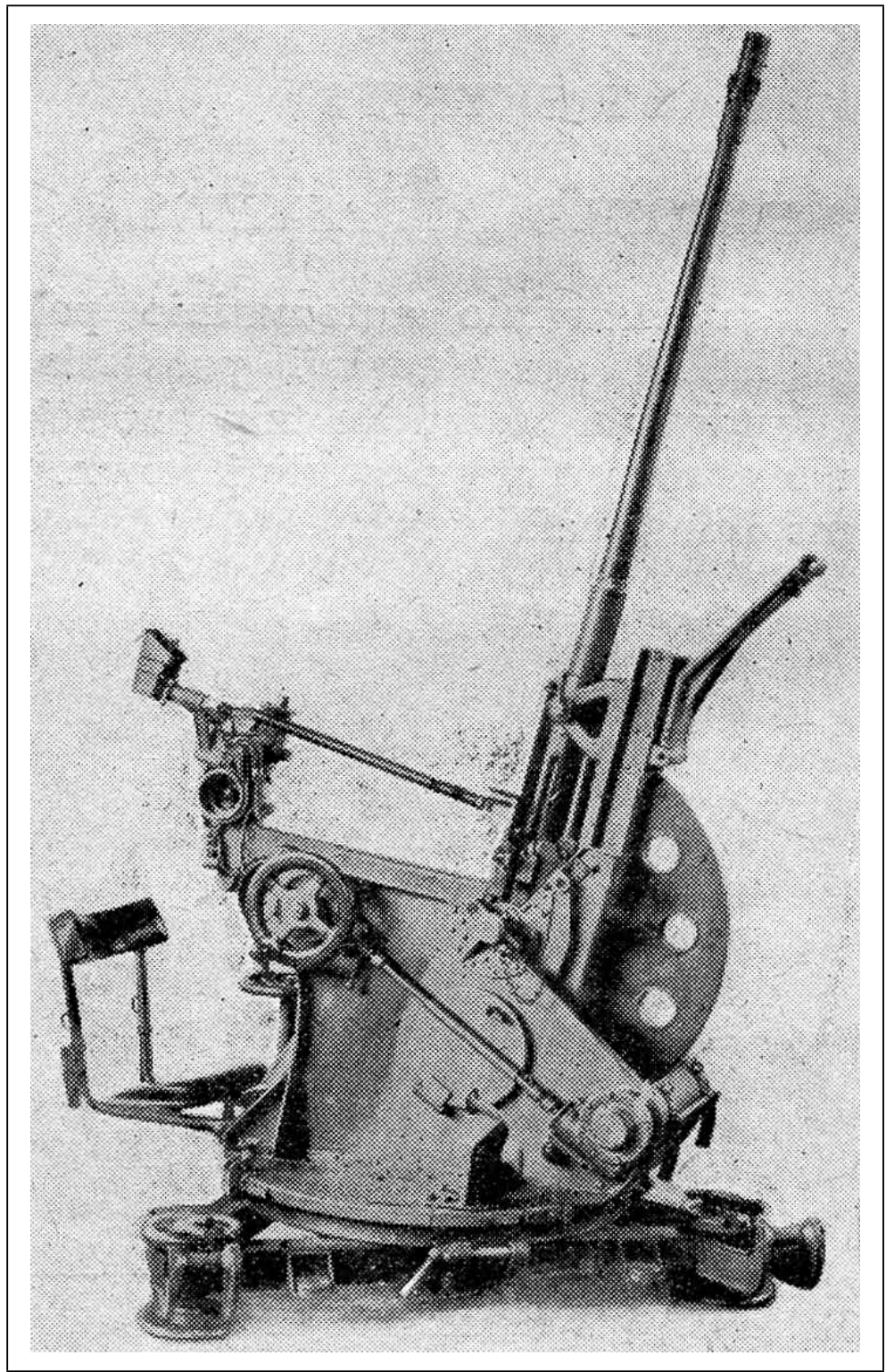

BSW, arba LAP (lekktuvinis automatinis pabūklas), $2 \mathrm{~cm}$ Flak 30 automatinis pabūklas parengtas šaudyti nuo stovo. Technika. P-85. Kaunas, 1940 
(Šančiuose), 3-ioji (III PD) - Šiauliuose, 4-oji (3-iajam PP) - Kèdainiuose, 5-oji (Šarvuočių rinktinei) - Radviliškyje ${ }^{211} .1939$ m. suformuotos LAP kuopos $1940 \mathrm{~m}$. kovo pabaigoje dar nebuvo galutinai sukomplektuotos, joms trūko vairuotojų. Esamus kuopų etatus buvo siūloma pertvarkyti - taikos metu formuoti po 2 būrius (kiekvienam skirti po $320 \mathrm{~mm}$ LAP), karo atveju - 4 analogiškus būrius ${ }^{212}$. Konstatuota, kad kariuomenèje yra apie 40 nepaskirstytų LAP pabūklų. PAR turèjo $640 \mathrm{~mm}$ Bofors priešlèktuvinius pabūklus, Centriniame artilerijos sandèlyje buvo daugiau kaip 20 nenaudojamų Hotchkiss kulkosvaidžių, todèl siūlyta formuoti atskirą priešlèktuvinès apsaugos batalioną ${ }^{213} .1940 \mathrm{~m}$. birželio $14 \mathrm{~d}$. buvo nurodyta vietoj Vilniaus komendantūros apsaugos bataliono suformuoti priešlèktuvinès apsaugos batalioną. Jị turèjo sudaryti 1 LAP kuopa (4 būriai po $320 \mathrm{~mm}$ BSW pabūklus), 1 baterija, ginkluota $640 \mathrm{~mm}$ Bofors pabūklais, ir sunkiųjų kulkosvaidžių kuopa ${ }^{214}$.

Iš internuotų lenkų karių buvo paimtos $575 \mathrm{~mm}$ patrankos. Jas nutarta perduoti daliniams, nes, suformavus 5 AP ir MAG atsargos AP, liko tik 2 haubicos, todèl 1-ąji AP rengtasi perginkluoti: I AG 2 baterijas $75 \mathrm{~mm}$ patrankomis, 1 bateriją - $105 \mathrm{~mm}$ haubicomis, II AG 2 baterijas - 76,2 mm patrankomis (atliekamų buvo tik 7), 1 bateriją - $105 \mathrm{~mm}$ haubicomis, o III AG visas 3 baterijas $-83,8 \mathrm{~mm}$ patrankomis ${ }^{215}$.

${ }^{211}$ İsakymas kariuomenei Nr. 14, 1939 m. rugsèjo 14 d. LCVA, f. 981, ap. 1, b. 4, 1. 1.

212 Pèstininkų inspekcijos 1940 m. kovo 29 d. raportas. LCVA, f. 929, ap. 5, b. 602, 1. 11.

${ }^{213}$ Batalioną galèjo sudaryti 3 LAP kuopos po 4 būrius (36 pabūklai), zenitinès artilerijos baterija (2 būriai po $340 \mathrm{~mm}$ Bofors pabūklus, iš viso 6), 1 sunkiųjų kulkosvaidžių kuopa (3 būriai po 6 Hotchkis kulkosvaidžius, iš viso 18). Likusius 4 - 5 LAP siūlyta palikti rezerve Linkaičiuose, juos karo atveju prižiūrètų ginklų dirbtuvių personalas. Žr.: Priešlèktuvinès apsaugos bataliono reikalu, 1940 m. birželio 13 d. LCVA, f. 929, ap. 5, b. 602, 1. 20-20 ap. 1.

${ }^{214}$ Kariuomenès štabas $1940 \mathrm{~m}$. birželio $14 \mathrm{~d}$. Vilniaus komendantui. LCVA, f. 929, ap. 5, b. $602,1.22$.

${ }^{215} 1940$ m. vyko artilerijos perdislokavimas: 1-asis AP karo atveju priklause V PD: I AG Ukmergèje, II AG Panevėžyje, III AG Kupiškyje. 2-asis AP priklausė IV PD: grupių dislokacijos vietos Kèdainiuose, Raseiniuose ir Seredžiuje nepakito. 3-iasis AP kilus karui turejjo sudaryti trijų AG pulką II PD sudètyje. 3-iojo AP I AG stovèjo Kaune, arkliai buvo pakeisti autotransportu, karo atveju planuota suformuoti motorizuotąją artilerijos grupę (MAG) iš $12105 \mathrm{~mm}$ haubicų, sudarančių kariuomenès artileriją. II AG Marijampolèje, III AG Kaune karo atveju iš mokomosios AG turejo būti suformuota 3-iojo AP I AG. 4-asis AP priklausė III PD, I AG Taurageje, II AG Plungeje, III AG Varniuose, IV AG Šiauliuose, kilus karui, turejo sudaryti 2 patrankų ir 1 haubicų $(2-155 \mathrm{~mm}$ haubicos $)$ bateriją. 5-asis AP karo atveju priklausè I PD, turejo būti formuojamas Vilniuje iš trijų 
Bendrai 1939 m. iš internuotų lenkų Lietuvos kariuomenè paème் $575 \mathrm{~mm}$ patrankas, $640 \mathrm{~mm}$ Bofors $1936 \mathrm{~m}$. pavyzdžio Lenkijoje pagamintus zenitinius automatinius pabūklus, kurių vienas (Nr. 633) buvo be spynos ir vamzdžio (vèliau gautas atsarginis vamzdis) ir dar vienas (Nr. 3556) - be spynos ir atsargos sparnelio, $981 \mathrm{~mm}$ w.z. 28 minosvaidžius, pagamintus 1928 m. (pastarieji - prastos techninès būklès ir aprūdiję) $)^{216}$.

Nepavyko išsiaiškinti vieno $120 \mathrm{~mm}$ ir dviejų $81,4 \mathrm{~mm} \mathrm{Brandt} \mathrm{minos-}$ vaidžių ịsigijimo 1939 m. ${ }^{217}$ aplinkybių. Gali būti, kad šie minosvaidžiai po demonstracinių ar kariuomenès bandymų buvo grąžinti juos pateikusioms firmoms, nes vèlesniuose sąrašuose jie neminimi.

$1940 \mathrm{~m}$. buvo suformuotas 5-ojo AP štabas Vilniuje, nors pulkas AG taikos metu neturèjo. Sostinèje buvo ịsikūrusi 1-ojo AP I AG. Štabas ateityje planavo karo atveju kurti 5 AP po 3 AG (iš viso 180 pabūklų), atsargos AP - 2 AG, taip pat motorizuotają AG (MAG) (12 pabūklų). Taigi būtų 18 AG, ginkluotų 216 pabūklų ${ }^{218}$. Nors būta minčių, kad ateityje 4-ajji AP sudarytų 4 AG. Štabas konstatavo, kad atsargos AP neturima ginkluotès, todèl buvo siūloma skubiai rusiškus ir angliškus pabūklus iškeisti i prancūziškus ir papildomai įsigyti dar $2575 \mathrm{~mm}$ patrankas ${ }^{219} .1940 \mathrm{~m}$. Lietuvos kariuomenę turëjo sudaryti 6 AP (1-asis, 2-asis, 3-iasis, 4-asis, 5-asis ir 11-asis - atsargos), Karo mokyklos AG ir 3 raitosios artilerijos baterijos ${ }^{220}$.

AG. Žr.: Artilerijos perorganizavimas, 1940 m. LCVA, f. 929, ap. 5, b. 591, 1. 3-3 ap. 1.

${ }^{216} 575$ mm patrankų Nr.: 23501, 24452, 3766, 24467 ir 22739; 640 mm Bofors pabūklų, pagamintų 1937 m. Nr.: 575, 578, 590, 591, 633, 1939 m. pagaminto pabūklo Nr. 3556; 81 mm w.z. 28 minosvaidžių Nr.: 238, 550, 249, 341, 478, 435, 487, 354, 502. Žr.: Internuotụjų ginklų apžiūrèjimo aktas, 1940 m. balandis. LCVA, f. 3, ap. 1, b. 433, 1. 3-15.

${ }^{217}$ Ginklavimo viršininkui apginklavimo žinios 1939.IX.1 LCVA, f. 3, ap. 1, b. 256, 1. 7.

${ }^{218} 1940 \mathrm{~m}$. Lietuva turejjo 219 lauko artilerijos patrankų ir haubicų: 111 - $75 \mathrm{~mm}, 19$ $76,2 \mathrm{~mm}, 12-83,8 \mathrm{~mm}, 4-105 \mathrm{~mm}$ čekiškų patrankų, 1 - $105 \mathrm{~mm}$ vokišką patranką, $70-105 \mathrm{~mm}$ ir $2-155 \mathrm{~mm}$ haubicas.

${ }^{219}$ Artilerijos perorganizavimas, 1940 m. LCVA, f. 929, ap. 5, b. 591, 1. 3-3 ap. 1.

${ }^{220} 1$-asis ir 2-asis AP turèjo po $2475 \mathrm{~mm}$ ir $12105 \mathrm{~mm}$ pabūklų, 3-iasis AP - $2075 \mathrm{~mm}$ ir 16 $105 \mathrm{~mm}, 4$-asis AP - $2475 \mathrm{~mm}, 883,4 \mathrm{~mm}, 12105 \mathrm{~mm}$ ir $2155 \mathrm{~mm}$ pabūklus (pulką turèjo sudaryti 4 AG, 3 po 12 pabūklų ir 1 iš 10 pabūklų), 5-asis AP - $1975 \mathrm{~mm}, 12105 \mathrm{~mm}$; 11 asis (atsargos) AP - 4 83,4 mm ir 2105 mm, Karo mokyklos AG - 7 76,2 mm ir 4105 mm, raitoji AG - $1276,2 \mathrm{~mm}$ pabūklų, Ginklavimo valdyboje liko $375 \mathrm{~mm}$ pabūklai, kurie netiko kautynėms. Iš viso buvo pabūklų: 114 - 75 mm (3 netiko kautynėms, 3, paimti iš lenkų, buvo perduoti 5-ojo AP mokomajai AG Vilniuje), 70 - 105 mm, 19 - 76,2 mm, 12 - 83,4 mm, 2 155 mm. Žr.: Pabūklų suskirstymo lentele, 1940 m. LCVA, f. 1373, ap. 1, b. 311, l. 101. 
1935-1940 m. perginkluojant ir plečiant Lietuvos kariuomenès artilerijos parką buvo padaryta milžiniška pažanga: lauko artilerijos pabūklų skaičius padidejo nuo 1181934 m. iki 2191940 m., jau nekalbant apie kokybinị šuolị - apie 1/3 pabūklų buvo visiškai naujo modelio haubicos. Ivairių pabūklų (pèstininkų, zenitinių, lauko artilerijos) bendras skaičius padidejo daugiau nei tris kartus - nuo 205 iki 645.

\section{ARTILERIJOS PABŪKLŲ POREIKIS IR ATEITIES VIZIJOS}

Septyneriu mety (1935-1941 m.) Lietuvos kariuomenès apginklavimo plano pirminiame variante buvo numatyta ginkluotès išteklius papildyti 271 artilerijos pabūklu. Iki $1940 \mathrm{~m}$. buvo ịsigytos $3675 \mathrm{~mm}$ ir $4105 \mathrm{~mm}$ patrankos, $70105 \mathrm{~mm}$ haubicų, 100 81,4 mm minosvaidžių. Taigi buvo igyvendinta apie $77,5 \%$ plano (gauta 210 iš 271 planuotų artilerijos pabūklų). 1937-1938 m. planai buvo patikslinti: įsigyta ne 40 trūkstamų $75 \mathrm{~mm}$ patrankų, o $50105 \mathrm{~mm}$ haubicu, ne 14, o $48155 \mathrm{~mm}$ haubicos, ne 14, o $24105 \mathrm{~mm}$ patrankos. Samprotauta, kad kariuomenei reiketų 380 (turèta 150, kariškiai pageidavo dar 230) $20 \mathrm{~mm}$ ir $8047 \mathrm{~mm}$ prieštankinių pabūklų 221. Šių prieštankinių pabūklų pirkimo galimybèmis domètasi Prancūzijoje (Schneider), Austrijoje (Böhler) ir Švedijoje (Bofors) ${ }^{222}$. Kariuomenès vadovybẻ pageidavo užsienyje ịsigyti $8047 \mathrm{~mm}$ prieštankinių pabūklų, bet, nepavykus to padaryti, planavo iš Prancūzijos firmos Schneider \& Cie už 790680 Lt pirkti licenciją ir juos gaminti Linkaičių ginklų dirbtuvése ${ }^{223}$. 1938 m. pabaigoje plk. ltn. Kazys Ambraziejus ir inž. Antanas Babilius net ruošèsi vykti ị Prancūziją rengti su firma Schneider \& Cie sutarties dèl licencijos gaminti $47 \mathrm{~mm}$ prieštankinius pabūklus ${ }^{224}$. Tačiau tolesnès licencijos pirkimo istorijos eigos mums atsekti nepavyko. Bet kokiu atveju aišku, kad iki okupacijos jų gamybos Lietuvoje pradèti nepavyko. 1939 m. Lietuvos ka-

${ }^{221}$ Kariuomenès ginklavimo viršininko 1937 m. gruodžio 15 d. raportas. LCVA, f. 929, ap. 9, b. 163, ap. 1. 9-10.

${ }^{222}$ Ginklavimo viršininko 1937 m. birželio 9 d. raportas. LCVA, f. 3, ap. 1, b. 287, 1. 70.

${ }^{223}$ Ministrui pirmininkui 1939 m. vasario 22 d. Nr. 1374. LCVA, f. 384, ap. 2, b. 1069 , 1. $120-121$.

${ }^{224}$ Ginklavimo valdybos 1938 m. gruodžio 1 d. raportas. LCVA, f. 3, ap. 1, b. 396, 1. 220. 
riuomeneje buvo parengti $47 \mathrm{~mm}$ ir $60 \mathrm{~mm}$ minosvaidžių brèžiniai, pabūklai pagaminti ir $1939 \mathrm{~m}$. lapkričio $11 \mathrm{~d}$. išbandyti ${ }^{225}$. KAM buvo numačiusi pagal Brandt licenciją pradèti gaminti $47 \mathrm{~mm}$ minosvaidžius Lietuvoje ${ }^{226}$.

Pagal Kariuomenès štabo planus ateityje karo sudèties PP turèjo sudaryti 13 prieštankinių pabūklų ( $4-47 \mathrm{~mm}$ ir $9-20 \mathrm{~mm}$ ), kiekvienas batalionas turèti 2 minosvaidžius ir 14 sunkiųjų kulkosvaidžių. Planuotas ginkluotès poreikis: karo meto kariuomenei, orientuojantis ị Vokietijos dalinių lygit, apginkluoti reikètú $17020 \mathrm{~mm}$ ir 204 37-47 mm prieštankinių pabūklų, o priešlèktuvinei gynybai - 242 pabūklų $(180-20 \mathrm{~mm}$, $26-40 \mathrm{~mm}$ ir $36-75 \mathrm{~mm})^{227}$.

1939-1941 m. buvo planuojama ịsigyti ịvairių ginklų ir amunicijos už $74,964 \mathrm{mln}$. Lt: $50105 \mathrm{~mm}$ haubicų už $5 \mathrm{mln}$. Lt ir 71600 jų sviedinių už $8,49 \mathrm{mln}$. Lt, 69800 sviedinių $75 \mathrm{~mm}$ patrankoms už $6,282 \mathrm{mln}$. Lt, $1075 \mathrm{~mm}$ priešlèktuvinių pabūklų ${ }^{228}$ už $2 \mathrm{mln}$. Lt ir 5000 sviedinių už

${ }^{225}$ Pociūnas A. Lietuvos kariuomenès minosvaidžiai 1921-1940 metais // Kardas, 2003, Nr. 2, p. 37.

${ }^{226}$ Pociūnas A. Lietuvos kariuomenès ginkluotè ir karinè pramonė 1939-1940 m. // Mokslas ir technika, 1993, Nr. 4, p. 31.

${ }^{227}$ Pèstininkų priemonių organizavimo klausimu. 1940 m. LCVA, f. 929, ap. 5, b. 591, 1. 11-12.

${ }^{228} 1938$ m. pabaigoje buvo svarstomos galimybès pirkti naujų vidutinio kalibro pabūklų. Rugsejjo 6-21 d. specialiai sudaryta komisija vertino 6 firmų pasiūlymus (Fried Krupp AG - Flak. 7,5 cm L/60 ir Flak. 8,8 cm L/56; Rheinmetall-Borsig AG - Flak. 7,5 cm L/59; Bofors - $80 \mathrm{~mm} \mathrm{L/50;} \mathrm{Škoda} \mathrm{-} \mathrm{CA} \mathrm{de} 75 \mathrm{~mm}$; Vickers-Armstrongs Ltd. - C.A. $75 \mathrm{~mm}$ ir Ansaldo - C.A. $75 \mathrm{~mm}$ ). Geriausiai buvo įvertinti vokiški pabūklai: 8,8 cm L/56 gavo 146 balus, 7,5 cm L/60 - 117, o 7,5 cm L/59 - 115 balų, kiti trys konkurentai pasirodė kur kas prasčiau ir negavo net po 100 balų. Visos firmos užsakymą siūlè atlikti per panašų laikotarpi (pusantrų-dvejus metus), palankiausia buvo Škoda firmos kaina, brangesni - vokiečių firmų pasiūlymai, didžiausia buvo Krupp nustatyta kaina- už $128,8 \mathrm{~cm}$ L/56 pabūklụ ir 3600 sviedinių - 4100808,48 Lt, o už 21 pabūklą ir 6300 sviedinių - 6820 599,24 Lt. Buvo siūloma ịsigyti 21 pabūklą. Žr.: Aktas, 1938 m. rugsèjo 6-21 d. LCVA, f. 3, ap. 1, b. 418, 1. 39-42. Iš parengtų sutarties projektų galime spèti, kad buvo nuspręsta įsigyti 12 $75 \mathrm{~mm}$ L/59 pabūklų (4 baterijas po 3 pabūklus) ir 3600 sviedinių, už pabūklą mokant po 92000 reichsmarkių (RM), už sviedinị - 113 RM, sandorio vertė - 1510800 RM (arba 3613834 Lt). Pirmoji partija - 3 pabūklai ir 900 sviedinių - turejo pasiekti Lietuvą iki 1940 m. rugsẻjo 1 d., antra, dvigubai didesnè, - iki tų pačių metų spalio 1 d., o trečioji - iki lapkričio 1 d. Žr.: Sutarties projektas 1938 m. LCVA, f. 3, ap. 1, b. 418, 1. 92-103. Rheinmetall-Borsig firma pirminiame pasiūlyme buvo nurodžiusi vieno pabūklo kainą 100000 RM (239200 Lt), sviedinio tokią pat - 113 RM (270,3 Lt), už 12 pabūklų ir 3600 
$1 \mathrm{mln}$. Lt, $8047 \mathrm{~mm}$ prieštankinių pabūklų už $4,8 \mathrm{mln}$. Lt ir 48000 sviedinių už 7,6 mln. Lt, $23020 \mathrm{~mm}$ prieštankinių pabūklų už $6,9 \mathrm{mln}$. Lt ir 460000 sviedinių už $6,9 \mathrm{mln}$. Lt, $31000020 \mathrm{~mm}$ Oerlikon pabūklų sviedinių už $6,5 \mathrm{mln}$. Lt, 60000 minosvaidžių minų už $2,1 \mathrm{mln}$. $\mathrm{Lt}^{229}$. Iš specialiųjų lèšų minètu laikotarpiu buvo numatyta įsigyti $1420 \mathrm{~mm}$ aviacijos pabūklų už $0,376 \mathrm{mln}$. Lt, $275 \mathrm{~mm}$ laivo pabūklus už $0,14 \mathrm{mln}$. Lt, $5,821 \mathrm{mln}$. Lt ketinta skirti prieštankinei artilerijai apginkluoti ${ }^{230} .1939 \mathrm{~m}$. D. Britanijoje norèta ịsigyti 10 priešlèktuvinių $75 \mathrm{~mm}$ pabūklų ir atitinkamos amunicijos ${ }^{231}$. Ši sprendimą, kuris skyrèsi nuo $1938 \mathrm{~m}$. deklaruoto nusistatymo pirkti vokiškų zenitinių pabūklų, galbūt lèmé politinès aplinkybès.

$1940 \mathrm{~m}$. sausio $27 \mathrm{~d}$. datuotame Maskvoje sudarytame dokumente nurodoma, kad Lietuva, remdamasi 1939 m. spalio $10 \mathrm{~d}$. savitarpio pagalbos sutarties 3 straipsniu, SSRS prašo parduoti $2575 \mathrm{~mm}$ patrankas, $40150 \mathrm{~mm}$ haubicų ir 32000 jų sviedinių, $15081 \mathrm{~mm}$ minosvaidžių ir $75000 \mathrm{minų,} 18037 \mathrm{~mm}$ arba $45 \mathrm{~mm}$ prieštankinių pabūklų ir 140000 jų sviedinių, $50045 \mathrm{~mm}$ granatsvaidžių ir 20000 granatų, 500 7,92 mm sunkiųjų ir tiek pat lengvųjų kulkosvaidžių, zenitinès artilerijos (76,2 mm) divizioną ir 14000 sviedinių. Taip pat ieškota galimybių turètas 76,2 mm ir $83,8 \mathrm{~mm}$ patrankas iškeisti ị prancūziškas $75 \mathrm{~mm} 1897 \mathrm{~m}$. patrankas ${ }^{232}$. Be to, aiškejja, kad 1940 m. Lietuva pirkti ginklų, paimtų iš Lenkijos kariuomenès, siekè ne tik SSRS, bet ir Vokietijoje. Buvo tikimasi gauti: $16037 \mathrm{~mm}$ prieštankinių pabūklų (norèta 225-250) ir 75000 sviedinių, 75 Brandt minosvaidžius ir 53000 minų (norèta 150-200), $25046 \mathrm{~mm}$

sviedinių norejo gauti $3843480 \mathrm{Lt}$, taigi padarè apie $6 \%$ nuolaidą. Žr.: Aktas, $1938 \mathrm{~m}$. rugsèjo 6-21 d. LCVA, f. 3, ap. 1, b. 418, 1. 39-42.

${ }^{229}$ Per likusị plano trimetị reikalinga įsigyti, 1938 m. gegužès 21 d. LCVA, f. 929, ap. 9, b. $163,1.22$.

${ }^{230}$ Numatoma įsigyti už specialias lèšas, 1938 m. gegužès 21 d. LCVA, f. 929, ap. 9, b. 163, 1. 24.

${ }^{231}$ Raportaskariuomenės tiekimoviršininkui, 1939 m.liepos 5 d.LCVA, f. 384, ap. 2.b, 1069, 1. 153-154.

${ }^{232}$ Be artilerijos, prašyta ir kitos ginkluotès: 32 T-26 tankų, 10 autocisternų ( $3 \mathrm{t}$ ), $100 \mathrm{ZIS}$ 3-4 t triašių sunkvežimių, 2000 lauko telefono aparatų, $11000 \mathrm{~km}$ telefono kabelio, 30 I-16 naikintuvų, 12 bombonešių, 16 aviacinių variklių (1100 AJ) ir propelerių, 70 aviacijos kulkosvaidžių, 150 lauko virtuvių ir kitų reikalingų kariuomenei priemonių. Žr.: Заявка, 27 января 1940 г. Москва. LCVA, f. 929, ap. 2, b. 1087, 1. 6. 
granatsvaidžių (norèta 500-600) ir 90000 granatų, apie 500 sunkiųjų kulkosvaidžių, 140 sunkvežimių, 20 tankų, 12 lèktuvų ir $3775 \mathrm{~mm}$ patrankas, iš viso už $17,058 \mathrm{mln}$. $\mathrm{Lt}^{233} .1940 \mathrm{~m}$. balandžio $30 \mathrm{~d}$. Lietuvos vyriausybé nutare skirti $21 \mathrm{mln}$. Lt, mokant 3 metus iki $1942 \mathrm{~m}$. po $7 \mathrm{mln}$. Lt, ginklams ir kitam kariniam turtui SSRS pirkti ${ }^{234}$.

Pažvelgę i kaimyninių mažujų valstybių artilerijos ginkluotès duomenis matome (7 lentelè), kad Lietuva pirmavo prieštankinių ir zenitinių pabūklų skaičiumi, lengvųjų haubicų turèjo daugiau nei Latvija ir Estija ir tiek pat, kiek Suomija, minosvaidžių skaičiumi lenkẻ kitas dvi Baltijos šalis, nors suomiai, patys šios ginkluotès gamintojai, jų turejjo daugiau nei tris kartus. Tačiau minèta persvara sumažètų arba net ištirptų, jei pabūklų skaičių ịvertintume atsižvelgdami ị šalių dydị (gyventojų skaičių). Žinoma, Lietuva pagal lauko ir sunkiosios artilerijos ginklų skaičių, bet, matyt, ne pagal jų kokybę, buvo autsaiderè.

Galima teigti, kad iki $1941 \mathrm{~m}$. pabaigos Lietuvos kariuomenè siekè issigyti nemažai artilerijos, planavo turèti gerokai per tūkstantị ịvairių sistemų pabūklų. Be to, nežinia, kiek būtų pagaminta $47 \mathrm{~mm}$ minosvaidžių. Planuoto patrankų ir haubicų skaičiaus turèjo užtekti mažiausiai 9 artilerijos pulkams, sudarytiems iš 3 artilerijos grupių, apginkluoti.

\section{IŠVADOS}

Galima išskirti keturis Lietuvos kariuomenès artilerijos ginkluotès raidos etapus: 1) 1919-1920 m. Nepriklausomybès kovų, kai artilerijos pabūklai buvo gauti iš Vokietijos ir $\mathrm{D}$. Britanijos arba paimti kaip karo grobis; 2) 1921-1928 m., kai buvo apsiribota Nepriklausomybès kovų metu įsigyta artilerija, o naujos ginkluotes pirkti dar tik planuota; 3) 1929-1934 m., kai buvo pradèti pirkti nauji artilerijos pabūklai; 4) 1935-1940 m. - kariuomenés artilerijos parko esminio atnaujinimo ir plètros igyvendinant septyneriu metu apginklavimo plana laikotarpis.

Trečiajame XX a. dešimtmetyje Lietuvos kariuomenei labai trūko artilerijos ginkluotès, turimi pabūklai neretai buvo susidèveję ir prastos kokybès. Ketvirtajame dešimtmetyje padètis kardinaliai pasikeite, ypač priešlèktuvinès ir prieštankinès artilerijos srityse, lauko artilerijos parkas, nors

\footnotetext{
${ }^{233}$ Kariuomenès vado pro memoria, 1940 m. balandžio 1 d. LCVA, f. 1, ap. 1, b. 541, 1. 64 . ${ }^{234}$ Kariuomenès tiekimo viršininko pro memoria, 1940 m. LCVA, f. 1, ap. 1, b. 541, 1. 69.
} 
ir atnaujintas, buvo ribotas - stokota pabūklų, ypač sunkiųjų. Akivaizdu, kad su turima artilerija, apie 18 lauko artilerijos grupių (1940 m. norèta mobilizuoti 18 péstininkų pulkų), buvo galima remti planuotų 5 péstininkų divizijų veiksmus ir iš dalies apsaugoti 3-4 stambesnius objektus (Kauną, Radviliškị, Linkaičius ir Vilnių), keletą tiltų ir slaptų aerodromų nuo priešo karo aviacijos atakų. Išskirtinis dėmesys priešlèktuvinei ir prieštankinei artilerijai atitiko tarpukariu plètotų karybos teorijų nuostatas: D. Britanijos gen. mjr. Johno Fredericko Charleso Fullerio - dèl tankų ir Italijos gen. Giulio Douheto - dèl oro pajègų dominavimo, nors, remiantis pastarąja, reikèjo sustiprinti vidutinę zenitinę artileriją, nes generolas siūlè taikyti masinio priešo objektų bombardavimo strategiją. O Vokietijos kariuomenès laimèjimai buvo pagrịsti glaudžiu oro ir sausumos pajėgų bendradarbiavimu, siekiant sutelktomis jègomis suduoti tikslius smūgius aviacijai, iš nedidelio aukščio tiesiogiai remiančiai savo puolančius dalinius.

Tai, kad Lietuvos kariuomenè turejo palyginti daug universalių $20 \mathrm{~mm}$ automatinių pabūklų, leidžia daryti prielaidą, kad eventualiai ji buvo viena iš geriausiai pasirengusių priešintis Blitzkrieg strategija besiremiančiai Vokietijos kariuomenei, kurios tankų divizijų veržimąsi rèmė pikiruojamieji bombonešiai, pajègų.

XX a. ketvirtajame dešimtmetyje pagrindinès artilerijos ginkluotès Lietuvai tiekejjos buvo Prancūzijos, Šveicarijos, Suomijos, D. Britanijos, Čekoslovakijos ir Vokietijos firmos, o lauko artilerijoje vyravo prancūzų gamybos pabūklai. Žinant, jog kaimyninëje Vokietijoje buvo įsigyta tik $20 \mathrm{~mm}$ priešlèktuvinių automatinių pabūklų, galima teigti, kad artilerijos priemonių pasirinkimą lèmè ne tik kariniai, techniniai argumentai, bet ir geopolitinès aplinkybès. Pabūklai (arba amunicija) buvo perkami iš tų gamintojų, iš kurių jų būtų galima gauti net ir karo su pagrindiniu priešu - Vokietija - atveju.

Lietuvos kariuomenès štabas suprato artilerijos karo metu svarbą ir ateityje planavo stiprinti sunkiąją lauko, ypač prieštankinę, ir priešlèktuvinę artileriją. Aiškejja, kad laikytasi naujausių tarpukario tendencijų, atsisakyta didinti lengvųjų lauko patrankų skaičių prioritetą teikiant haubicoms. Kovos su tankais ir priešo karo aviacija aktualumas ir problemiškumas ypač išryškèjo Lenkijos karinès kampanijos 1939 m. rugsèji metu. Susiklosčius sudètingai tarptautinei situacijai buvo bandoma ne tik papildomai issigyti artilerijos pabūklų Vokietijoje ir SSRS, bet ir organizuoti péstininkų 
lydimosios artilerijos priemonių gamybą Lietuvoje (Linkaičių dirbtuvėse).

\section{PRIEDAI}

1 lentelè Lietuvos kariuomenès artilerijos ginkluotė 1920-1940 m.

\begin{tabular}{|c|c|c|c|c|c|c|c|c|}
\hline $\begin{array}{l}\text { Pabūklo } \\
\text { modelis }\end{array}$ & 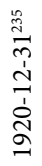 & 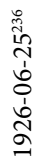 & 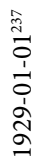 & 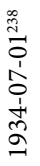 & 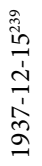 & 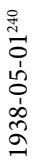 & 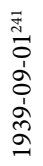 & 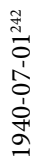 \\
\hline $\begin{array}{l}77 \mathrm{~mm} 1896 \mathrm{~m} . \\
\text { patrankos }\end{array}$ & 8 & \multirow{2}{*}{26} & \multirow{2}{*}{29} & 5 & - & - & - & - \\
\hline $\begin{array}{l}77 \mathrm{~mm} 1916 \mathrm{~m} . \\
\text { patrankos }\end{array}$ & 23 & & & 22 & - & - & - & - \\
\hline 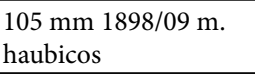 & 9 & 9 & 10 & 9 & - & - & - & - \\
\hline $\begin{array}{l}105 \mathrm{~mm} 10 \mathrm{~cm} \mathrm{~K} 17 \\
\text { patrankos }\end{array}$ & - & 1 & - & 1 & - & - & 1 & 1 \\
\hline $\begin{array}{l}57 \mathrm{~mm} \text { Nordenfelt } \\
\text { kaponieriu patrankos }\end{array}$ & 6 & 2 & 5 & 5 & - & - & - & - \\
\hline
\end{tabular}

${ }^{235}$ Liubinas V. Mūsų ginklai 1919-1920 metais // Mūsų žinynas, 1938, T. 35, Nr. 11-12, p. 777.

${ }^{236}$ Vyriausiojo štabo artilerijos inspekcijos $1926 \mathrm{~m}$. birželio 25 d. raportas. LCVA, f. 929, ap. 3, b. 536, 1. 77-80; Žinios apie minosvaidžių stovị 1929 m. liepos 8 d. LCVA, f. 929, ap. 3, b. $655,1.57$.

237 Žinios apie ginklų skaičių Lietuvos kariuomenejje ir artilerijos sandèliuose (atsargoj) 1929 m. sausio 1 d. LCVA, f. 929, ap. 3, b. 655, 1. 72; Žinios apie ginklų skaičių Lietuvos kariuomeneje ir artilerijos sandèliuose (atsargoj) 1929 m. balandžio 1 d. LCVA, f. 929, ap. 3, b. 655, 1. 77; Žinios apie ginklų skaičių Lietuvos kariuomenejje ir artilerijos sandèliuose (atsargoj) 1929 m. liepos 1 d. LCVA, f. 929, ap. 3, b. 655, 1. 82.

238 Žinios 1934 m. liepos 1 d. LCVA, f. 929, ap. 3, b. 889, 1. 4; Kariuomenès apsiginklavimo stovis 1934 m. spalio 25 d. LCVA, f. 929, ap. 3, b. 889, 1. 3.

${ }^{239}$ Kariuomenès štabo žinios apie esamą ir numatomą apginklavimą $1937 \mathrm{~m}$. gruodžio 15 d. LCVA, f. 1, ap. 1, b. 385, 1. 37-38.

240 Žinios apie ginklų bei amunicijos stovị 1938 m. gegužès 1 d. LCVA, f. 929, ap. 9, b. 163, 1. 25 .

${ }^{241}$ Ginklavimo viršininkui apginklavimo žinios 1939 m. rugsejjo 1 d. LCVA, f. 3, ap. 1, b. $256,1.7$.

${ }^{242}$ Ginklavimo turto stovio žinios 1940 m. liepos 1 d. LCVA, f. 3, ap. 1, b. 256, 1. 11. 
Lietuvos kariuomenès artilerijos pabūklai 1919-1940 m.

\begin{tabular}{|c|c|c|c|c|c|c|c|c|}
\hline $\begin{array}{l}37 \mathrm{~mm} \text { Krupp zenitinès } \\
\text { patrankos }\end{array}$ & 2 & 2 & 2 & 3 & - & - & - & - \\
\hline $37 \mathrm{~mm}$ tankų patrankos & - & - & - & 3 & - & - & - & - \\
\hline $\begin{array}{l}105 \mathrm{~mm} \text { Škoda } \\
\text { patrankos }\end{array}$ & - & & - & - & - & - & - & 4 \\
\hline $\begin{array}{l}76,2 \mathrm{~mm} 1902 \mathrm{~m} . \\
\text { patrankos }\end{array}$ & 21 & 18 & 19 & 19 & 19 & 19 & 19 & 19 \\
\hline Rusiška 48 linijų & 1 & & & & & & & \\
\hline $\begin{array}{l}75 \mathrm{~mm} \text { Schneider } \\
1897 \mathrm{~m} . \text { patrankos }\end{array}$ & 16 & 14 & 16 & 36 & 108 & 108 & 108 & 111 \\
\hline $\begin{array}{l}83,8 \mathrm{~mm} \text { II Mk } \\
\text { patrankos }\end{array}$ & 4 & 4 & 4 & 4 & 4 & 4 & 4 & 4 \\
\hline $\begin{array}{l}83,8 \mathrm{~mm} \text { IV Mk } \\
\text { patrankos }\end{array}$ & - & - & 8 & 8 & 8 & 8 & 8 & 8 \\
\hline $\begin{array}{l}105 \mathrm{~mm} 1934 \mathrm{~m} . \\
\text { haubicos }\end{array}$ & - & - & - & - & 48 & 70 & 70 & 70 \\
\hline $\begin{array}{l}155 \mathrm{~mm} \text { Schneider } \\
1917 \mathrm{~m} . \text { haubicos }\end{array}$ & 2 & 2 & 2 & 2 & 2 & 2 & 2 & 2 \\
\hline $\begin{array}{l}127 \mathrm{~mm} \text { Vickers- } \\
\text { Armstrong haubicos }\end{array}$ & 12 & 12 & 12 & 12 & - & - & - & - \\
\hline $\begin{array}{l}75 \mathrm{~mm} \text { Vickers- } \\
\text { Armstrong zenitinès } \\
\text { patrankos }\end{array}$ & - & - & - & - & 9 & 9 & 9 & 9 \\
\hline Sviediniai & 170156 & 170008 & - & - & 129800 & 172600 & 188305 & 217080 \\
\hline $20 \mathrm{~mm}$ Oerlikon & - & - & - & 50 & 150 & 150 & 151 & 151 \\
\hline $2 \mathrm{~cm}$ Flak 30 & - & - & - & - & - & - & 75 & 150 \\
\hline $20 \mathrm{~mm}$ sviediniai & - & - & - & & 100000 & 100000 & 187635 & 203763 \\
\hline $\begin{array}{l}40 \mathrm{~mm} w z .36 \text { Bofors } \\
\text { zenitinès patrankos }\end{array}$ & - & - & - & - & - & - & - & $5(6)^{243}$ \\
\hline $40 \mathrm{~mm}$ sviediniai & - & - & - & - & - & - & - & 2120 \\
\hline Minosvaidžiai & & & & & & & & \\
\hline $81,4 \mathrm{~mm}$ Brandt $1934 \mathrm{~m}$. & - & - & - & - & 100 & 100 & 102 & 110 \\
\hline $\begin{array}{l}75,8 \mathrm{~mm} \text { lengvieji } \\
\text { minosvaidžiai }\end{array}$ & \multirow{3}{*}{26} & 8 & & \multirow{3}{*}{26} & - & - & - & - \\
\hline $\begin{array}{l}170 \mathrm{~mm} \text { vidutiniai } \\
\text { minosvaidžiai }\end{array}$ & & 19 & & & - & - & - & - \\
\hline $\begin{array}{l}250 \text { mm sunkieji } \\
\text { minosvaidžiai }\end{array}$ & & 4 & & & - & - & - & - \\
\hline Minosvaidžių minos & 36084 & 3450 & & & & 29396 & 33295 & 32458 \\
\hline Iš viso pabūklų & 130 & 121 & $\begin{array}{c}\mathbf{1 0 7} \\
(133)\end{array}$ & 205 & 448 & 470 & 549 & 645 \\
\hline
\end{tabular}

${ }^{243}$ Priešlèktuvinès apsaugos bataliono reikalu, 1940 m. birželio 13 d. LCVA, f. 929, ap. 5, b. $602,1.20$. 
2 lentele 1919-1940 m. Lietuvos kariuomenès naudotų artilerijos pabūklų techniniai duomenys ${ }^{244}$

\begin{tabular}{|c|c|c|c|c|c|c|c|c|c|}
\hline$\frac{n}{\tilde{\pi}}$ & 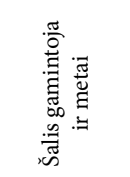 & 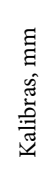 & 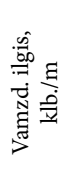 & 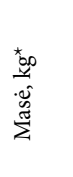 & 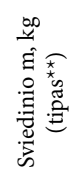 & 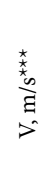 & 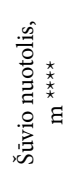 & 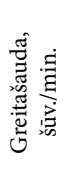 & 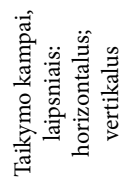 \\
\hline $\begin{array}{l}105 \mathrm{~mm} \\
\text { patranka Škoda }\end{array}$ & $\begin{array}{l}\text { Čekoslo- } \\
\text { vakija, } \\
1935\end{array}$ & 105 & $\begin{array}{l}48 / \\
5,04\end{array}$ & $\begin{array}{l}4950 / \\
5425\end{array}$ & $\begin{array}{c}16,5-17 \\
G\end{array}$ & 850 & 20000 & 5 & $50^{\circ} 0^{\prime} ; 45^{\circ} 0^{\prime}$ \\
\hline $\begin{array}{l}76,2 \mathrm{~mm} 1902 \mathrm{~m} . \\
\text { patranka }\end{array}$ & $\begin{array}{c}\text { Rusija, } \\
1902\end{array}$ & 76,2 & $\begin{array}{c}30 / \\
1,79\end{array}$ & $\begin{array}{l}1100 / \\
1949\end{array}$ & $\begin{array}{l}\text { 6,2-6,5 } \\
\text { G, }, \breve{S}\end{array}$ & 588 & 11300 & 10 & $\begin{array}{l}5^{\circ} 30^{\prime} ; \\
16^{\circ} 40^{\prime}\end{array}$ \\
\hline $\begin{array}{l}84 \mathrm{~mm} \text { Vickers } \\
\text { Mk II patranka }\end{array}$ & $\begin{array}{c}\text { D. Britanija, } \\
1904\end{array}$ & 83,8 & $\begin{array}{l}19,4 / \\
2,038\end{array}$ & $\begin{array}{l}1280 / \\
2055\end{array}$ & $\begin{array}{l}8,4 \\
\mathrm{G}, \check{S}\end{array}$ & 550 & 5950 & 8 & $8^{\circ} 0^{\prime} ; 37^{\circ} 30^{\prime}$ \\
\hline $\begin{array}{l}84 \mathrm{~mm} \text { Vickers } \\
M k I V \\
\text { patranka }\end{array}$ & D. Britanija & 83,8 & $\begin{array}{l}19,4 / \\
2,038\end{array}$ & $\begin{array}{l}1454 / \\
2180\end{array}$ & $\begin{array}{l}8,4 \\
\mathrm{G}, \check{S}\end{array}$ & 550 & 9600 & 8 & $8^{\circ} 0^{\prime} ; 37^{\circ} 30^{\prime}$ \\
\hline $\begin{array}{l}75 \mathrm{~mm} 1897 \mathrm{~m} . \\
\text { patranka }\end{array}$ & $\begin{array}{c}\text { Prancūzija, } \\
1897\end{array}$ & 75 & $\begin{array}{c}30 / \\
2,230\end{array}$ & $\begin{array}{l}1140 / \\
1942\end{array}$ & $\begin{array}{c}5,4-7,2 \\
G, \breve{S}\end{array}$ & 559 & 10800 & 10 & $6^{\circ} 0^{\prime} ; 18^{\circ} 0^{\prime}$ \\
\hline $\begin{array}{l}105 \mathrm{~mm} 1934 \mathrm{~m} . \\
\text { haubica }\end{array}$ & $\begin{array}{c}\text { Prancūzija, } \\
1934\end{array}$ & 105 & $\begin{array}{l}15,3 / \\
1,614\end{array}$ & $\begin{array}{l}1755 / \\
2546\end{array}$ & $\begin{array}{c}15,3- \\
15,6 \\
G\end{array}$ & 465 & 11000 & 5 & $40^{\circ} 0^{\prime} ; 43^{\circ} 0^{\prime}$ \\
\hline
\end{tabular}

244 Štabų žinynas. Kaunas, 1938, p. 44-49, 157; Žinios apie Ginklavimo valdybos tiekiamų pabūklų, pirmagalių, šovinių dèžių ir kitus duomenis 1939 m. balandžio 20 d. LCVA, f. 3, ap. 1, b. 478, 1. 182; Das Feldgeschutze 96 N/A. Mašinraštis [data nenurodyta]. LCVA, f. 3, ap. 1, b. 472, 1. 35-36; Artilerijos statutas. IV dalis. Pabūklai ir šaudmenys: b) $76 \mathrm{~mm}$ 1902 m. patranka. Kaunas, 1939, p. 8-10; Clarce D. British Artillery 1914-1919. Field Army Artillery. Oxford, 2004, P. 33-36, 39; Artilerijos statutas A-53. IV dalis: a) $75 \mathrm{~mm}$ 1897 m. patranka. Kaunas, 1938, p. 8-10; Vauvillier F. Lartillerie de campagne divisionnaire en 1940 // Tank Zone, 2008, No. 1, p. 65; Bytautas P. Artilerijos vadovélis. II dalis. Kaunas, 1927, p. 102-105, 111-113, 119; 77 mm. 1916 metu lauko patranka. I dalis. Liemuo. Kaunas, 1928, p. 41; 77 mm. 1916 metu lauko patranka. II dalis. Lafetas. Kaunas, 1929, p. 89; Šių laikų artilerija ir jos vartojimas manevrų kare // Mūsų žinynas, 1922, Nr. 1, p. 7-8, 18; Engelmann J. German Light Field Artillery 1935-1945. Atglen, 1995, P. 5; Широкорад А. Энииклопедия отечественной артиллерии. Минск, 2006, с. 245-250; $81 \mathrm{~mm}$ minosvaidis. Technika. P-84. Kaunas, 1939, p. 20; $81 \mathrm{~mm}$ minosvaidžiu mokymo statutas. Kaunas, 1940, p. 105-106; Minosvaidžiu vadovèlis. Kaunas, 1924, p. 6-7, 89-90; Rozwadowski P. Polskie armaty przeciwlotnicze $75 \mathrm{~mm}$ wz.36/37 oraz $40 \mathrm{~mm}$ „Bofors“ // Typy Broni i Uzbrojenia, No. 183, Warszawa, 1998, s. 25, 28, 32; Péstininku statutas. Kautynes. II dalis. Kaunas, 1939, p. 33; 20 mm automatine patranka „Oerlikon“. Laikinoji instrukcija. Kaunas, 1935, p. 22-23; 20 mm lèktuvinis automatinis pabūklas (LAP). Kaunas, 1940, p. 227-228. 
Lietuvos kariuomenès artilerijos pabūklai 1919-1940 m.

\begin{tabular}{|c|c|c|c|c|c|c|c|c|c|}
\hline $\begin{array}{l}155 \mathrm{~mm} 1917 \mathrm{~m} . \\
\text { haubica }\end{array}$ & \begin{tabular}{|c|} 
Prancūzija, \\
1917 \\
\end{tabular} & 155 & $\begin{array}{c}15 / \\
2,23 \\
\end{array}$ & $\begin{array}{l}3300 / \\
3715 \\
\end{array}$ & 43,5 & 450 & 11900 & 4 & $6^{\circ} ; 0+42^{\circ}$ \\
\hline $\begin{array}{l}127 \mathrm{~mm} \\
\text { Armstrong } \\
\text { haubica }\end{array}$ & $\begin{array}{c}\text { D. Britanija, } \\
1898\end{array}$ & 127 & $\begin{array}{l}8,4 / \\
1,07\end{array}$ & 1370 & $\begin{array}{c}22,7 \\
18,1\end{array}$ & 240 & $\begin{array}{l}4400- \\
5900\end{array}$ & 4 & $8^{\circ} ;-5+45^{\circ}$ \\
\hline $\begin{array}{l}77 \mathrm{~mm} 1896 \mathrm{~m} . \\
\text { (N/A) patranka }\end{array}$ & $\begin{array}{c}\text { Vokietija, } \\
1896\end{array}$ & 77 & $2,08 \mathrm{~m}$ & $\begin{array}{l}1020 / \\
1910\end{array}$ & 6,85 & 465 & $\begin{array}{l}5000- \\
7800\end{array}$ & $10-16$ & $7^{\circ} ;-10+16^{\circ}$ \\
\hline $\begin{array}{l}77 \mathrm{~mm} 16 \mathrm{~m} . \\
\text { lauko patranka }\end{array}$ & $\begin{array}{c}\text { Vokietija, } \\
1916\end{array}$ & 77 & $\begin{array}{c}35 \mathrm{klb} / \\
2695\end{array}$ & $1325 /$ & $\begin{array}{c}5,85- \\
7,2 \\
\end{array}$ & $\begin{array}{l}430- \\
602 \\
\end{array}$ & $\begin{array}{l}6000- \\
10700\end{array}$ & $\begin{array}{c}6 \\
120 / \mathrm{h}\end{array}$ & $4^{\circ} ;-10+38^{\circ}$ \\
\hline $\begin{array}{l}105 \mathrm{~mm} \mathrm{98/09} \\
\text { metų haubica }\end{array}$ & $\begin{array}{c}\text { Vokietija, } \\
1909\end{array}$ & 105 & $\begin{array}{l}22,5 / \\
1,625\end{array}$ & $\begin{array}{l}1225 / \\
2260\end{array}$ & 16 & 330 & 7000 & 2 & $4^{\circ} ;-9+42^{\circ}$ \\
\hline $\begin{array}{l}105 \mathrm{~mm} \\
16 \mathrm{~m} . \text { haubica }\end{array}$ & $\begin{array}{l}\text { Vokietija, } \\
1916\end{array}$ & 105 & $/ 2.29$ & $\begin{array}{l}1525 / \\
2870\end{array}$ & 16 & 395 & 9225 & 2 & $4^{\circ} ;-9+44^{\circ}$ \\
\hline $\begin{array}{l}10 \mathrm{~cm} \mathrm{K17} \\
\text { patranka }\end{array}$ & $\begin{array}{c}\text { Vokietija, } \\
1917\end{array}$ & 105 & $\begin{array}{c}45 / \\
2,036\end{array}$ & 3300 & 18,75 & 650 & 16500 & 1 & $6^{\circ} ;-2+45^{\circ}$ \\
\hline $\begin{array}{l}57 \mathrm{~mm} \\
\text { Nordenfeld } \\
\text { kaponieriaus } \\
\text { patranka }\end{array}$ & Rusija, 1892 & 57 & $\begin{array}{l}26,4 / \\
1,504\end{array}$ & 196,5 & $\begin{array}{c}0,17 \\
\mathrm{G}, \check{S}, \mathrm{~K}\end{array}$ & 384 & $900(\check{S})$ & $12-16$ & \\
\hline $\begin{array}{l}81 \mathrm{~mm} \text { Brandt } \\
1934 \mathrm{~m} .\end{array}$ & $\begin{array}{c}\text { Suomija, } \\
1935\end{array}$ & 81,4 & 1263,5 & 60,2 & $\begin{array}{c}3,43 \\
6,5\end{array}$ & & $\begin{array}{l}3000 \\
1100\end{array}$ & $18-30$ & \\
\hline $\begin{array}{l}7,58 \mathrm{~cm} \text { leMW } \\
\text { a.A }\end{array}$ & $\begin{array}{c}\text { Vokietija, } \\
1914\end{array}$ & 75,8 & $\begin{array}{c}3,1 / \\
0,235\end{array}$ & 147 & 4,56 & 90 & $\begin{array}{l}300- \\
1300\end{array}$ & 6 & $7^{\circ} ;+45+78^{\circ}$ \\
\hline $\begin{array}{l}7,58 \mathrm{~cm} \text { leMW } \\
\text { n.A }\end{array}$ & $\begin{array}{c}\text { Vokietija, } \\
1916\end{array}$ & 75,85 & $/ 0,445$ & $\begin{array}{c}215 / \\
275\end{array}$ & 4,6 & $\begin{array}{c}100- \\
120\end{array}$ & $\begin{array}{l}1300 ; \\
2400\end{array}$ & $4-20$ & $\begin{array}{c}360^{\circ} \mathrm{su} \\
\text { platforma }\end{array}$ \\
\hline $17 \mathrm{~cm} \mathrm{mMW} \mathrm{a.A}$ & $\begin{array}{c}\text { Vokietija, } \\
1913\end{array}$ & 170 & $\begin{array}{c}4,5 / \\
0,765\end{array}$ & 483 & $50-55$ & 200 & $\begin{array}{l}300- \\
1600\end{array}$ & 20 & $\begin{array}{c}25^{\circ} \\
+45+90^{\circ}\end{array}$ \\
\hline $17 \mathrm{~cm} \mathrm{mMW} \mathrm{n.A}$ & $\begin{array}{l}\text { Vokietija, } \\
1916\end{array}$ & 170 & $\begin{array}{c}\text { / } \\
0,772\end{array}$ & $\begin{array}{c}585 / \\
880\end{array}$ & $50-55$ & 75 & $\begin{array}{l}1170 \\
1600\end{array}$ & $\begin{array}{l}1-3 \\
\text { š. } / 2 \\
\mathrm{~min}\end{array}$ & $25^{\circ}$ \\
\hline $25 \mathrm{~cm} \mathrm{sMW} \mathrm{n.A}$ & $\begin{array}{c}\text { Vokietija, } \\
1916\end{array}$ & 250 & 5 & $\begin{array}{l}780 / \\
1077\end{array}$ & 95 & 50 & $190-970$ & $\begin{array}{c}1-2 \\
\check{s} / 3 \mathrm{~min}\end{array}$ & \\
\hline $25 \mathrm{~cm}$ sMW a.A & Vokietija, & 250 & 3 & 628 & 92 & 50 & 563 & $20 \mathrm{š} / \mathrm{h}$ & \\
\hline $\begin{array}{l}75 \mathrm{~mm} \text { Vickers- } \\
\text { Armstrong }\end{array}$ & D. Britanija & 75 & $40 /$ & 3000 & 6,6 & 750 & $\begin{array}{l}10350 / \\
15000\end{array}$ & 30 & $\begin{array}{c}360^{\circ} ; \\
-10+90^{\circ}\end{array}$ \\
\hline $\begin{array}{l}40 \mathrm{~mm} \text { wz. } 36 \\
\text { Bofors }\end{array}$ & $\begin{array}{c}\text { Lenkija, } \\
1936\end{array}$ & 40 & $\begin{array}{r}56 / \\
2,24\end{array}$ & $\begin{array}{l}1730 / \\
2320 \\
\end{array}$ & $\begin{array}{c}0,91- \\
0,95 \\
\end{array}$ & $\begin{array}{r}823- \\
875 \\
\end{array}$ & $\begin{array}{l}4500 / \\
9500\end{array}$ & $\begin{array}{c}100- \\
120 \\
\end{array}$ & $\begin{aligned} & 360^{\circ} ; \\
&-6^{\circ}+90^{\circ}\end{aligned}$ \\
\hline $20 \mathrm{~mm}$ Oerlikon & $\begin{array}{c}\text { Šveicarija, } \\
1934\end{array}$ & 20 & $\begin{array}{l}65 / \\
1,3\end{array}$ & $\begin{array}{c}310 / \\
850\end{array}$ & $\begin{array}{c}0,244- \\
0,257\end{array}$ & 830 & $\begin{array}{c}2000 / \\
4000\end{array}$ & $\begin{array}{c}200- \\
280\end{array}$ & $360^{\circ} ;+90^{\circ}$ \\
\hline $\begin{array}{l}20 \mathrm{~mm} L A P \\
(B S W)^{* * * * *}\end{array}$ & $\begin{array}{c}\text { Vokietija, } \\
1939\end{array}$ & 20 & $\begin{array}{l}65 / \\
1,3\end{array}$ & $\begin{array}{l}450 / \\
750\end{array}$ & $\begin{array}{c}0,318- \\
0,337\end{array}$ & $\begin{array}{c}815- \\
835\end{array}$ & $\begin{array}{c}3700 / \\
5000\end{array}$ & $\begin{array}{c}280- \\
300\end{array}$ & $360^{\circ} ; 10+90^{\circ}$ \\
\hline $3,7 \mathrm{~cm}$ SockelFlak & Vokietija & 37 & 14,5 & & 0,45 & 350 & 2200 & 120 & $360^{\circ} ;+90^{\circ}$ \\
\hline
\end{tabular}

* Kovos/žygio

${ }^{* *} \mathrm{G}$ - granata, $\check{S}$ - šrapnelis, $\mathrm{K}$ - kartečè

${ }^{* * *}$ Pradinis sviedinio greitis

**** Zenitinių pabūklų vertikalus/horizontalus šaudymo nuotolis

***** Vokietijos kariuomenejje pabūklai, vadinti $2 \mathrm{~cm}$ Flak 30 
3 lentelè Baltijos šalių ir Suomijos sausumos pajegų artilerijos pabūklai $1939-1940 \mathrm{~m}$.

\begin{tabular}{lllll} 
& \multicolumn{1}{c}{ Lietuva } & \multicolumn{1}{c}{ Latvija $^{245}$} & Estija $^{246}$ & Suomija \\
Minosvaidžiai & $102(+9)$ & 66 & 34 & 360 \\
Zenitiniai pabūklai & $84(+81)$ & $38(+6)$ & 47 & $122^{*}$ \\
$\begin{array}{l}\text { Prieštankiniai pabūklai } \\
70 \text { mm péstininkų pabūklai }\end{array}$ & 151 & 116 & 63 & 112 \\
$\begin{array}{l}75-83,8 \text { mm lengvosios } \\
\text { patrankos }\end{array}$ & $139(+3(5))^{* *}$ & $199(228)^{* * *}$ & $174^{* * * *}$ & 293 \\
$\begin{array}{l}105-114,3 \text { mm lengvosios } \\
\text { haubicos }\end{array}$ & 70 & $52(+12)$ & 28 & 70 \\
$\begin{array}{l}105-114,3 \text { mm sunkiosios } \\
\text { patrankos }\end{array}$ & $1(+4)$ & 25 & 24 & 11 \\
$\begin{array}{l}150-155 \text { mm sunkiosios } \\
\text { haubicos }\end{array}$ & 2 & 17 & 42 & 32
\end{tabular}

* $34-20 \mathrm{~mm}, 52-40 \mathrm{~mm}$ Bofors ir $36-76 \mathrm{~mm}$ priešlèktuviniai pabūklai

** $1939 \mathrm{~m}$. iš internuotų Lenkijos pajègų buvo paimtos $575 \mathrm{~mm}$ patrankos, tačiau tik 3 buvo tinkamos naudoti

*** $199-83,8$ mm patrankos, $27-76,2 \mathrm{~mm}$ šarvuotųjų traukinių patrankos ir $2-75 \mathrm{~mm}$ kalnų patrankos

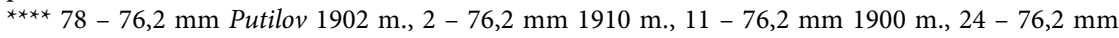
1897 m., 59 - 83,8 mm Mk. I 1904 m. patrankos

Iteikta $2011 \mathrm{~m}$. spalio $17 \mathrm{~d}$.

${ }^{245}$ Latvijos kariuomenè aptariamuoju laikotarpiu turèjo $6681,4 \mathrm{~mm}$ Stokc-Brandt $1930 \mathrm{~m}$. minosvaidžius, 6 - 76,2 mm $1931 \mathrm{~m}$. sovietinius, $24-76,2 \mathrm{~mm} 1915 \mathrm{~m}$., 18 $40 \mathrm{~mm}$ Bofors, 2 - $40 \mathrm{~mm}$ Vickers-Armstrong zenitinius pabūklus, $116-47 \mathrm{~mm}$ Böhler prieštankinių pabūklų, $24-70 \mathrm{~mm}$ Škoda M28 péstininkų patrankas, $27-75 \mathrm{~mm}$ patrankas (traukiniuose), 2 - $75 \mathrm{~mm}$ kalnų patrankas, 199 - 83,8 mm angliškas patrankas, 8 - $105 \mathrm{~mm}$ Krupp, $12-105 \mathrm{~mm}$ Reinmetall ir $44-114,3 \mathrm{~mm}$ lengvąsias haubicas; 19 - $107 \mathrm{~mm} 1910 \mathrm{~m}$. ir 6 - 114,3 mm sunkiąsias patrankas, 9 - 6“ (152,4 $\mathrm{mm})$ rusiškas Vickers, 3 - 6“ (152,4 mm) rusiškas Schneider ir 5 - 150 mm 1916 m. vokiškas Krupp sunkiąsias haubicas; 9 - 152,4 mm Canet ir 2 - $130 \mathrm{~mm} / 55$ Vickers jūrinius pabūklus, 9 - 80 mm laivyno pabūklus. Istoriografijoje teigiama, kad Latvija 1939-1940 m. ịsigijo $86105 \mathrm{~mm}$ Škoda haubicas, tačiau iki okupacijos šie pabūklai Latvijos nepasiekè. Žr.: Vaičenonis J. Lietuvos kariuomenès modernizacija (1926-1939) // Darbai ir dienos. T. 21. Kaunas, 2001, p. 146; Кудряшов И. Ю. Вооруженные силь Латвийской Республики в 1940 году. Москва, 1991 (рукопись); Nõmm T. Eesti suurtükivägi 1918-1940. Relvastus ja ülesehitus // Laidoneri muuseumi aastaraamat. Nr. 4. Tallinn, 2005, 1. 189, 204-205; 
Salo U. Eesti kaitseväe valmisolek sõjaks ja vastupanuvõimalused 1939. aastal. Magistro baigiamasis darbas. Tartu, 2005 [PDF.]. Tartu, 2005, p. 298; Pētersons A. Krustugnis. 60 gadus no tautas slēptais 1940-1945. Rīga: Madonas pligrāfists, 2007, p. 122; 3ccepтc M. Железнодорожная артиллерия Латвии // Baltfort, Рига, 2010, Nr. 3 (12), с. 42.

${ }^{246}$ Estijos kariuomenè turèjo 34 minosvaidžius, 44 - $37 \mathrm{~mm}$ Rheinmetall, $4-47 \mathrm{~mm}$ Böhler, 15 - 20 mm prieštankinių pabūklų, 47 - zenitinius pabūklus; 78 - 76,2 mm Putilov 1902 m., 2 - 76,2 mm 1910 m., 24 - 76,2 mm 1897 m., 59 - 83,8 mm Mk. I 1904 m. patrankas; 6 - 107 mm Schneider 1910 m., 14 - 107 mm Creusot 1913 m., 4 - 119 mm angliškas Mk. I sunkiąsias patrankas; 28 - 114,3 mm (jau priklausè užsienio firmai) lengvąsias haubicas, 8 - 150 mm 1913 m., 5 - 152 mm Vickers, 29 - 152 mm Schneider 1909 m. sunkiąsias haubicas. Pakrančių artileriją sudarė $337 \mathrm{~mm}$ zenitiniai pabūklai, 11 76,2 mm 1900 m., 4 - 120 mm Vickers, 7 - 130 mm Vickers, 15 - 152,4 mm Canet, 3 - 234 mm, 4 - $305 \mathrm{~mm}$ pabūklai. Be to, buvo $10152 \mathrm{~mm} 1877 \mathrm{~m}$. (iš jų 4 - pakrančių apsaugos baterijose) patrankų. Žr.: Эстония. Энциклопедический справочник. Ред. А. Раукас. Таллинн, 2008, с. 54; Kaasik P. The Liquidation of the Estonian Defence League in 1940 // Estonia 1940-1945. Reports of the Estonian International Commission for the Investigation of Crimes Against Humanity. Ed. by T. Hiio, M. Maripuu, I. Paavle. Tallinn, 2006, p. 131-132, 136; Eesti vabariik enne teist maailmasõda [žiūrèta 201012 05]. Interneto prieiga: <http://www.hot.ee/vabadussoda/ajalugu_11.htm>; Nõmm T. Eesti suurtükivägi 1918-1940. Relvastus ja ülesehitus // Laidoneri muuseumi aastaraamat. Nr. 4. Tallinn, 2005, 1. 189, 204-205; Salo U. Eesti kaitseväe valmisolek sõjaks ja vastupanuvõimalused 1939. aastal. Magistro baigiamasis darbas. Tartu, 2005 [PDF]. Tartu, 2005, p. 298.

${ }^{247} 1939 \mathrm{~m}$. Suomija turèjo $36081 \mathrm{~mm}$ minosvaidžių, 34 - $20 \mathrm{~mm}, 52$ - $40 \mathrm{~mm}$ Bofors ir $36-76 \mathrm{~mm}$ priešlèktuvinius pabūklus, 112 - $37 \mathrm{~mm}$ Bofors prieštankinių pabūklų; 293 - 76,2 mm lengvąsias patrankas (21 - 76,2 mm 1900 m., 192 - 76,2 mm 1902 m., 72 76,2 mm 1910 m., 1913 m., 8 - 76,2 mm 1922/23 m.), 70 - 122 mm lengvųjų haubicų, $11-107 \mathrm{~mm} 1910 \mathrm{~m}$. sunkiụjų patrankų, $32-150 \mathrm{~mm}$ ir $152 \mathrm{~mm}$ sunkiąsias haubicas (iš jų 12 - 150 mm japoniškų M14, 8 - 152 mm 1909 m., 12 - 152 mm Canet), dar 174 senus, menkos kovinès vertès pabūklus ( 86 - $80 \mathrm{~mm} 90 \mathrm{~mm}$ ir $88-150 \mathrm{~mm} 1877 \mathrm{~m}$. patrankas). Kiti autoriai nurodo buvus 282 senus pabūklus: 80 - 87 mm 1877/95 m., $114-107$ mm 1877 m., 88 - 152 mm 1877 m. Žr.: Paulaharju J. Kenttätykistö talvisodassa. // Sotahistoriallinen Aikakauskirja. Nr. 19. Helsinki, 2000, 1. 110; Kiukkanen J. Talvisodan puolustus-ministeri kertoo. Helsinki, 1951, 1. 173-181; Nõmm T. Eesti suurtükivägi 1918-1940. Relvastus ja ülesehitus. // Laidoneri muuseumi aastaraamat. Nr. 4. Tallinn, 2005, 1. 189. Pakrančių artilerijoje buvo daugiau kaip 174 artilerijos pabūklai, tarp jų 8 - $305 \mathrm{~mm}, 26$ 254 mm, 6 - 234 mm, 2 - 203 mm, 81 - 152 mm, 7 - 120 mm, 18 - 87 mm, 10 - 75 mm, 16 - 57 mm patrankų. Žr.: Широкорад А. Б. Северные войны России. Москва, 2001 [žiūrèta 201012 05]. Interneto prieiga: <http://militera.lib.ru/h/shirokorad1/9_02.html>. 


\title{
CANONS DE L'ARTILLERIE DE L'ARMÉE LITUANIENNE DANS LES ANNÉES 1919-1940
}

\author{
Vytautas Jokubauskas, \\ Université de Klaipèda \\ Egidijus Papečkys
}

L'artillerie de l'armée lituanienne d’entre-guerre était commencée à former en 1919 après avoir reçu de l'Allemagne les premiers canons russes et puis, lors de la guerre de l'Indépendance, les armes étaient reçues de la Grande Bretagne ou elles étaient prises des soldats soviétiques et polonais comme le butin militaire. Après avoir terminé la guerre, le parc d’artillerie était assez misère, le 25 juin 1926 l'armée lituanienne avait 90 canons d'artillerie et 31 „mortier“ („mortier lance-mines“), qui étaient souvent en très bas état technique. Des essais à acquérir de nouveaux canons nétait pas successives jusqu'au des années 1929, l'attention était donc concentrée sur la réparation des anciens canons.

L’armement d'artillerie était commencé à reconstituer dans les années 1929-1934. Tout d'abord il était acheté huit canons de 83,8 millimètres de la Grande Bretagne, puis un peu plus tard vingt canons de 20 millimètres, 156 canons automatiques Oerlikon de75 millimètres et neuf canons anti-aériens de 75 millimètres. De cette manière la 1 juillet 1934 le parc d'artillerie était formé par les 205 bouchons à feu, obusier, canons antiaériensantichars automatiques et „mortier“ („mortier lance-mines“). Après avoir commencé à exécuter le plan de l'armée de sept ans en 1935, l’armement de l'armée s'est changé d'une manière méconnaissable. Des anciens canons allemands étaient vendus et les unités étaient équipées par les bouchons à feu du calibre standardisé de 75 millimètres et des obusier de 105 millimètres, quoique les nombre des bouchons à feu de 76,2 et de 83,8 millimètres était relativement négligeable. Toutefois il y avait l'intention en perspective d'augmenter le nombre de l'artillerie lourde qui était le talon d'Achille du parc d'artillerie de l'armée lituanienne. Il y avait aussi le plan à augmenter le nombre des obusier de 105 millimètres, à acquérir des bou- 
chons à feu de 105 millimètres ainsi que des obusier de 155 millimètres. Il était donc acheté 24 bouchons à feu Skoda de 105 millimètres, mais après avoir commencé la Deuxième guerre mondiale en Europe, la Lituanie ne recevait que quatre canons jusquà son occupation. À case de la guerre mentionnée, il était très difficile à acquérir l’armement désiré. Pour cette raison, la fabrication des canons antichars et des „mortier“ („mortier lance-mines") était commencée à planifier en Lituanie.

Lattention spécifique de l'armée lituanienne dans la deuxième moitié de la quatrième décennie de XX siècle était destinée pour la défense antiaérienne et antichar. La conception de l'utilisation des canons légers antiaériens était choisisse exactement, et dans les années 1940 il y avait plus que 300 canons automatiques de 20 millimètres qui pouvait s'avérer après avoir s'attelé la Lituanie au conflit armé prenant en considération l'expérience de la Seconde guerre mondiale. En général, dans les années 1940 l'armée lituanienne avait 645 canons de l'artillerie de champs, antiaériens et antichars de même que des „mortier“ („mortier lance-mines“) ainsi qu'environ $90 \%$ était acquis pendant la dernière décennie (en 1929-1940).

La plus grande partie de l'armement d'artillerie de l'armée lituanienne était acheté en France, en Grande Bretagne, en Suisse, à Finlande et en république de Tchèque, et dans les années 1938-1940 des 150 canons automatiques Flak de 2 centimètres étaient achetés en Allemagne pendant que des essais à acquérir de l'armement de l'Union soviétique lors de toute la période de l'entre-guerre, nétait pas successifs. Il est possible donc de constater que les pays baltes n’avaient pas de la politique générale de l'armement de ses armées et les canons de l'artillerie étaient des systèmes et des calibres différents. En général, en analysant l'armement de l'artillerie lituanienne dans le contexte des pays nordiques, de Lettonie, de l'Estonie et de la Finlande, les armements de ces derniers avaient beaucoup plus de canons d'artillerie de champs, mais l'armement lituanien était le plus neuf et innové grâce à une application d'obusier. En outre, le nombre des canons antichars et antiaériens de même que des profectifs des mines était plus grand que ce de Lettonie, et même l'Estonie. 


\title{
LITHUANIAN ARMY ARTILLERY CANNONS IN 1919-1940
}

\author{
Vytautas Jokubauskas, \\ Klaipéda University \\ Egidijus Papečkys
}

Interwar Lithuanian army artillery was started up in 1919, after receiving first Russian cannons from Germany; later, during the Independence War, the guns were obtained from Great Britain or taken from the Soviets, Bermontians and Poles as war booty. After the war fights artillery park was quite poor; on 25 June 1926, Lithuanian army had 90 cannons and 31 mortars that were often in poor technical condition. The attempts to acquire new cannons were unsuccessful even until 1929; therefore, the focus was on the repair of the possessed cannons.

In 1929-1934 artillery weaponry was started to be updated; first, in 1929, 8 - 83.8 $\mathrm{mm}$ cannons were purchased from Great Britain, a year later $20-75 \mathrm{~mm}$ cannons, 156 - $20 \mathrm{~mm}$ Oerlikon automatic cannons and $9-75 \mathrm{~mm}$ anti-aircraft cannons were purchased. In this way on 1 July 1934, army artillery park consisted of 205 cannons, howitzers, anti-aircraft and anti-tank automatic cannons and mortars. When Lithuania started to implement a seven-year plan of equipping the army, the artillery munitions changed beyond recognition. Old German cannons were sold and units were equipped with the $75 \mathrm{~mm}$ cannons of standardized calibre and the $105 \mathrm{~mm}$. howitzers, though there was still a relatively small number of the $76.2 \mathrm{~mm}$ and the $83.8 \mathrm{~mm}$ cannons left. In the future there were intentions to increase the number of heavy artillery, which can be said to have been Achilles' heel of the Lithuanian army artillery park. It was planned to increase the number of the $105 \mathrm{~mm}$ howitzers and to purchase the $105 \mathrm{~mm}$ cannons and the $155 \mathrm{~mm}$ howitzers. The 24 - 105 mm Škoda cannons were bought, however due to the breakout of the Second World War in Europe only four cannons reached Lithuania before its occupation. Due to the aforementioned war it was difficult to purchase the desired weaponry, therefore, there were plans made to pro- 
duce anti-tank cannons and mortars in Lithuania.

In the late 1930's, particular attention in the Lithuanian Army was given to anti-tank and anti-aircraft defence. In 1940, more than 300 automatic $20 \mathrm{~mm}$ cannons were possessed; in principle the concept of the utilization of light anti-aircraft cannons was chosen aptly, and given the experience of the Second World War, it would have proven out if Lithuania had got involved in an armed conflict. Overall in 1940, the Lithuanian army had 645 field artillery, anti-aircraft and anti-tank cannons and mortars; and about $90 \%$ of them were purchased over the last decade (1929-1940).

The biggest part of the Lithuanian army artillery weaponry was purchased in France, Great Britain, Switzerland, Finland and Czechoslovakia, while in 1938-1940, 150 - 2 cm Flak 30 automatic cannons were also purchased in Germany. Practically during the entire interwar period all attempts to purchase weaponry from the USSR were unsuccessful. It can be stated that the Baltic States did not have a common armament policy of their armies and their artillery cannons were of different calibres and systems, although in some cases they were the same. In general, regarding Lithuanian artillery weaponry in the context of the northern countries such as Latvia, Estonia and Finland, it is obvious that the latter countries had more field artillery cannons, however, the Lithuanian munitions were the newest and an innovative way was chosen by regarding howitzers as a priority. Moreover, the number of anti-tank and antiaircraft cannons and mortars in the Lithuanian army was higher than in Latvia and particularly in Estonia. 